
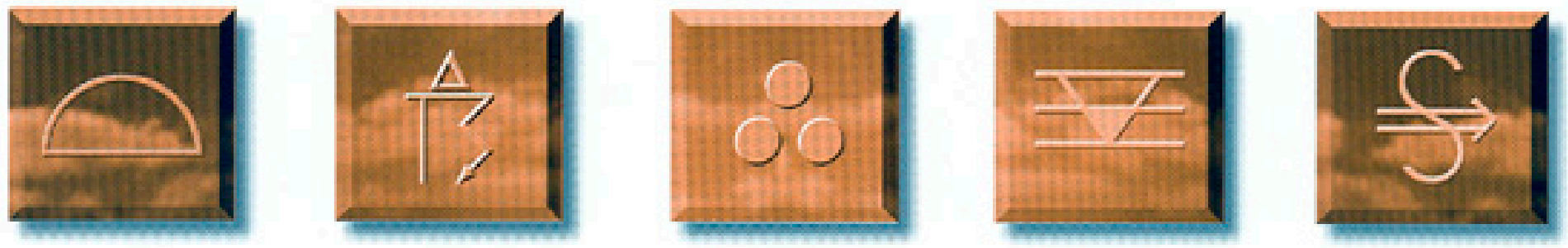

\section{ШІЕСТИ- И ТРЕХ-ЧАСОВЫЕ} МЕТЕОРОЛОГИЧЕСКИЕ

НАБЛЮДЕНИЯ ПО ДАННЫМ 223-х СТАНЦИЙ СССР

В. Н. Разуваев E. Г. Апазова P. A. Мартуганов Всероссийский Научно-Исследовательский Унспитут

І идрометеорологической Унформашиц

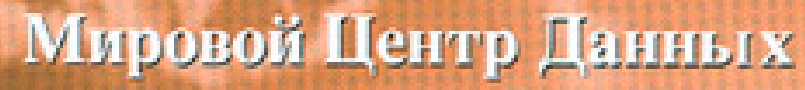
Об̆mincк, Poecug:
Six- and Three-Hourly Meteorological Observations from 223 U.S.S.R. Stations

V. N. Razuvaev

E. B. Apasova

R. A. Martuganov

All-Russian Research

Institute of

Hydrometeorological

Information -

World Data

center

Obninsk, Russia 


\title{
SIX- AND THREE-HOURLY METEOROLOGICAL OBSERVATIONS FROM 223 U.S.S.R. STATIONS
}

\author{
Contributed by \\ V. N. Razuvaev, E. B. Apasova, R. A. Martuganov \\ All-Russian Research Institute \\ of Hydrometeorological Information - World Data Centre \\ Obninsk, Russia
}

Prepared by D. P. Kaiser

Carbon Dioxide Information Analysis Center

Oak Ridge National Laboratory

Oak Ridge, Tennessee

Environmental Sciences Division

Publication No. 4398

Date Published-April 1995

Prepared for the

Global Change Research Program

Environmental Sciences Division

Office of Health and Environmental Research

Budget Activity Number KP 0502000

Prepared by the

OAK RIDGE NATIONAL LABORATORY

Oak Ridge, Tennessee 37831-6335

managed by

MARTIN MARIETTA ENERGY SYSTEMS, INC. for the

U.S. DEPARTMENT OF ENERGY

under contract DE-AC05-84OR21400

Funded in part by the

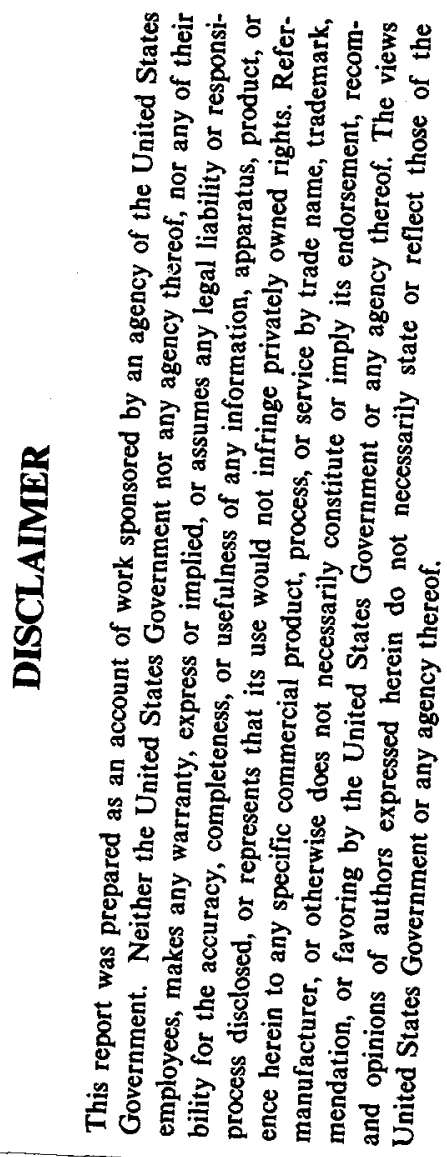

National Oceanic and Atmospheric Administration's

Climate and Global Change Program 



\section{DISCLAIMER}

Portions of this document may be illegible in electronic image products. Images are produced from the best available original document. 


\title{
IIЕСТИ- И ТРЕХ-ЧАСОВЫЕ МЕТЕОРОЛОГИЧЕСКИЕ НАБЛПОДЕНИЯ ПО ДАННЫМ 223-х СТАНЩИЙ СССР
}

\author{
В. Н. Разуваев, Е. Г. Апазова, Р. А. Мартуганов \\ Всероссийский Научно-Исследовательский Институт \\ Гидрометеорологической Информации \\ Мировой Центр Данных \\ Обнинск, Россия \\ Подготовлено Дейлом П. Кайзером \\ Центр Анализа Информапии по Углекислому Газу \\ Окриджская Национальная Лаборатория \\ Ок Ридж, Теннесси
}

Издание Отделения Экологических Наук №. 4398

Дата Публикации-Апрель 1995 года
Подготовлено в рамках научно-исследовательской программы по изучению Глобаљных Изменений Климата
Отделение Экологических Наук
Управление Научных Исследований по Охране Здоровья
и Окружающей Среды
Департамент Энергетики CIIA
KII 0502000

Подготовлено Центром Анализа Информации по Углекислому Газу

Окриджская Национальная Лаборатория

Ок Ридж, Теннесси 37831-6335

Лаборатория управляется фирмой

МАРТИН МАРИЕТТА ЭНЕРДЖИ СИСТЕМС, ИНК.

согЛасно договору с ДЕПАРТАМЕНТОМ ЭНЕРГЕТИКИ США

ㄱ. ДЕ-АC05-84OP21400

Финансовый спонсор

Национальная Администрация по изучению Океана и Атмосферы

в рамках научно-исследовательской программы

по изучению Глобальных Изменений Климата 

TABLE OF CONTENTS

LIST OF FIGURES $\ldots \ldots \ldots \ldots \ldots \ldots \ldots \ldots \ldots \ldots \ldots \ldots \ldots \ldots$ vii

LIST OF TABLES $\ldots \ldots \ldots \ldots \ldots \ldots \ldots \ldots \ldots \ldots \ldots \ldots \ldots \ldots \ldots$

ABSTRACT $\ldots \ldots \ldots \ldots \ldots \ldots \ldots \ldots \ldots \ldots \ldots \ldots \ldots \ldots \ldots \ldots \ldots \ldots$

PART 1: OVERVIEW OF THE DATABASE $\ldots \ldots \ldots \ldots \ldots \ldots \ldots \ldots$

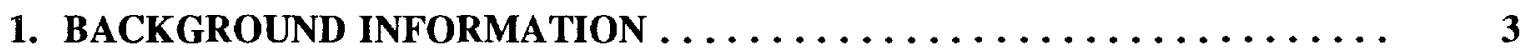

2. DESCRIPTION OF THE DATABASE ................. 3

3. CDIAC quality assurance CHECks $\ldots \ldots \ldots \ldots \ldots \ldots \ldots \ldots$

4. HOW TO OBTAIN THE PACKAgE $\ldots \ldots \ldots \ldots \ldots \ldots \ldots \ldots \ldots \ldots$

5. REFERENCES $\ldots \ldots \ldots \ldots \ldots \ldots \ldots \ldots \ldots \ldots \ldots \ldots \ldots \ldots \ldots \ldots$

PART 2: CONTENT AND FORMAT OF DATA FILES $\ldots \ldots \ldots \ldots \ldots$

6. FILE DESCRIPTIONS $\ldots \ldots \ldots \ldots \ldots \ldots \ldots \ldots \ldots \ldots \ldots \ldots \ldots \ldots$

NDP048.DES (FILE 1) $\ldots \ldots \ldots \ldots \ldots \ldots \ldots \ldots \ldots \ldots \ldots \ldots \ldots$

INVENT.FOR (FILE 2$) \ldots \ldots \ldots \ldots \ldots \ldots \ldots \ldots \ldots \ldots \ldots \ldots$

GAPS.FOR (FILE 3) $\ldots \ldots \ldots \ldots \ldots \ldots \ldots \ldots \ldots \ldots \ldots \ldots \ldots$

TIMEZONE.FOR (FILE 4) $\ldots \ldots \ldots \ldots \ldots \ldots \ldots \ldots \ldots \ldots \ldots \ldots$

HISTORY.FOR (FILE 5) $\ldots \ldots \ldots \ldots \ldots \ldots \ldots \ldots \ldots \ldots \ldots \ldots$

DATA.FOR (FILE 6) $\ldots \ldots \ldots \ldots \ldots \ldots \ldots \ldots \ldots \ldots \ldots \ldots \ldots$

INVENT.SAS (FILE 7) ..................... 29

GAPS.SAS $($ FILE 8$) \ldots \ldots \ldots \ldots \ldots \ldots \ldots \ldots \ldots \ldots \ldots \ldots \ldots$

TIMEZONE.SAS $($ FILE 9) $\ldots \ldots \ldots \ldots \ldots \ldots \ldots \ldots \ldots \ldots \ldots \ldots$

HISTORY.SAS (FILE 10) . . . . . . . . . . . . . . 29 
DATA.SAS (FILE 11) . . . . . . . . . . . . . . $\ldots \ldots \ldots$

STATION.INV (FILE 12) $\ldots \ldots \ldots \ldots \ldots \ldots \ldots \ldots \ldots \ldots \ldots \ldots \ldots$

GAPS.DAT (FILE 13) $\ldots \ldots \ldots \ldots \ldots \ldots \ldots \ldots \ldots \ldots \ldots \ldots \ldots \ldots$

TIMEZONE.DAT (FILE 14) $\ldots \ldots \ldots \ldots \ldots \ldots \ldots \ldots \ldots \ldots \ldots \ldots$

STATION.HIS (FILE 15) $\ldots \ldots \ldots \ldots \ldots \ldots \ldots \ldots \ldots \ldots \ldots \ldots \ldots$

USSR01.DAT-USSR25.DAT (Files 16-40) ............... 33

7. VERIFICATION OF DATA TRANSPORT $\ldots \ldots \ldots \ldots \ldots \ldots \ldots \ldots \ldots$

APPENDICES $\ldots \ldots \ldots \ldots \ldots \ldots \ldots \ldots \ldots \ldots \ldots \ldots \ldots \ldots \ldots \ldots \ldots \ldots \ldots$

APPENDIX A: STATION HISTORIES $\ldots \ldots \ldots \ldots \ldots \ldots \ldots \ldots \ldots \ldots$ A-1

APPENDIX B: REPRINT OF PERTINENT LITERATURE $\ldots \ldots \ldots \ldots \ldots \ldots$ B-1

A New Perspective on Recent Global Warming: Asymmetric Trends of Daily Maximum and Minimum Temperature.

T. R. Karl, P. D. Jones, R. W. Knight, G. Kukla, N. Plummer, V. Razuvaev, K. P. Gallo, J. Lindseay, R. J. Charlson, and T. C. Peterson 


\section{LIST OF FIGURES}

Figure

Page

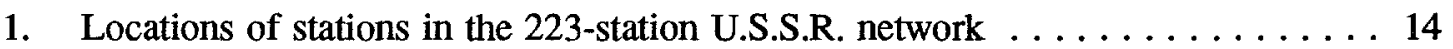





\section{LIST OF TABLES}

$\underline{\text { Table }}$

$\underline{\text { Page }}$

1. Inventory of stations in the 223 -station U.S.S.R. network $\ldots \ldots \ldots \ldots \ldots$

2. Gaps in the periods of record of the 223 U.S.S.R. stations $\ldots \ldots \ldots \ldots \ldots$

3. Size and format information for the NDP files $\ldots \ldots \ldots \ldots \ldots \ldots \ldots$

4. Partial listing of the file station.inv (File 12) $\ldots \ldots \ldots \ldots \ldots \ldots \ldots \ldots$

5. Partial listing of the file gaps.dat (File 13$) \ldots \ldots \ldots \ldots \ldots \ldots \ldots \ldots \ldots$

6. Partial listing of the file timezone.dat (File 14) $\ldots \ldots \ldots \ldots \ldots \ldots \ldots$

7. Partial listing of the file station.his (File 15) $\ldots \ldots \ldots \ldots \ldots \ldots \ldots$

8. Partial listings of the files ussr01.dat-ussr25.dat (Files $16-40) \ldots \ldots \ldots 5$ 



\begin{abstract}
RAZUVAEV, V. N., E. G. APASOVA, and R. A. MARTUGANOV. 1995. Six- and Three-hourly Meteorological Observations from 223 U.S.S.R. Stations. ORNL/CDIAC-66, NDP-048. Carbon Dioxide Information Analysis Center, Oak Ridge National Laboratory, Oak Ridge, Tennessee. 133 pp. doi: 10.3334/CDIAC/cli.ndp048
\end{abstract}

This document describes a database containing 6- and 3-hourly meteorological observations from a 223-station network of the former Soviet Union. These data have been made available through cooperation between the two principal climate data centers of the United States and Russia: the National Climatic Data Center (NCDC), in Asheville, North Carolina, and the All-Russian Research Institute of Hydrometeorological Information - World Data Centre (RIHMI-WDC) in Obninsk. Station records consist of 6- and 3-hourly observations of some 24 meteorological variables including temperature, weather type, precipitation amount, cloud amount and type, sea level pressure, relative humidity, and wind direction and speed. The 6-hourly observations extend from 1936 to 1965; the 3-hourly observations extend from 1966 through the mid-1980s (1983, 1984, 1985, or 1986; depending on the station). These data have undergone extensive quality assurance checks by RIHMIWDC, NCDC, and the Carbon Dioxide Information Analysis Center (CDIAC). The database represents a wealth of meteorological information for a large and climatologically important portion of the earth's land area, and should prove extremely useful for a wide variety of regional climate change studies.

These data are available free of charge as a numeric data package (NDP) from CDIAC. The NDP consists of this document and 40 data files that are available via the Internet or on $8 \mathrm{~mm}$ tape. The total size of the database is -2.6 gigabytes.

Keywords: $\quad$ U.S.S.R., former Soviet Union, Russia, hourly data, air temperature, dew point temperature, relative humidity, water vapor pressure, sea level pressure, visibility, cloud amount, cloud height, wind direction, wind speed, precipitation amount, soil temperature, weather type, atmospheric phenomena 



\section{PEЗIOME}

РАЗУВАЕВ, В. Н., Е. Г. АПАЗОВА, Р. А. МАРТУГАНОВ. 1995. Шести- и трехчасовые метеорологические наблюдения по данным 223-х станций СССР. ОРНЛ/ЦАИ-66, ПЦД-048, Центр Анализа Информации по Углекислому Газу Окриджская Национальная Лаборатория, Ок Ридж, Теннесси. 133 стр.

Настоящий документ представляет описание базы данных, содержащей шести- и трех-часовые метеорологические наблюдения по данным 223-х станций бывшего Советского Союза. Эти данные оказались доступными благодаря сотрудничеству между двумя центрами климатических данных Соединенных Штатов Америки и России: Национальный Центр Климатических Данных (НЦКД) в Ашвилле, Северная Каролина и Научно-Исследовательский Институт Гидрометеорологической Информации - Мировой Центр Данных (ВНИИГМИ-МЦД) в Обнинске, Россия. Архивы станционных данных содержат записи 6- и 3-часовых наблюдений примерно 24x метеорологических переменных, включая температуру, тип погоды, количество осадков, облачность, давление на уровне моря, относительную влажность, а так же скорость и направление ветра. 6-часовые наблюдения были собраны в период с 1936 по 1965 годы; 3-часовые наблюдения проводились, начиная с 1966 года до середины 1980-х годов $(1983,1984,1985$, или 1986, в зависимости от станции). Все данные были подвержены тщательной проверке на качество во ВНИИГМИ-МЦД, НЦКД и Центре Анализа Информации по Углекислому Газу (ЦАИ). База данных содержит богатую метеорологическую информацию по огромной, климатически важной части суши Земли, и должна представлять болышую пользу в процессе изучения регионального изменения климата.

Настоящие данные можно заказать бесплатно в виде Пакета Цифровых Данных (ПЦД) через ЦАИ. ПЦД состоит из настоящего документа и 40 файлов, которые доступны через Интернет или на 8-мм магнитной ленте. Общий объем базы данных составляет примерно 2.6 гигавайт.

Ключевые слова: ССР, бывший Советский Союз, почасовые данные, температура воздуха, температура точки росы, относительная влажность, испарение, давление на уровне моря, видимость, облачность, высота облаков, направление ветра, скоростъ ветра, количество осадков, температура почвы, тип погоды, атмосферный феномен. 


\section{PART 1}

OVERVIEW OF THE DATABASE 



\section{BACKGROUND INFORMATION}

In recent years, a great deal of meteorological data have been exchanged between the two principal climate data centers of the United States and the former Soviet Union: the National Climatic Data Center (NCDC), in Asheville, North Carolina, and the All-Russian Research Institute of Hydrometeorological Information-World Data Centre (RIHMI-WDC) in Obninsk, Russia. This was accomplished via Working Group VIII (Influence of Environmental Changes on Climate) of the bilateral initiative known as the Agreement on Protection of the Environment, established on May 23, 1972, by the United States and the U.S.S.R. Working Group VIII established the Climate Data Exchange and Management Agreement Project, the purpose of which is to promote the sharing of climatological data between NCDC and RIHMIWDC. Surface meteorological and climatological data for the U.S.S.R. that have been received by NCDC from RIHMI-WDC to date include

- monthly mean temperature data from 243 stations (1891-1988),

- daily temperature and precipitation data from 223 stations (1881-1989),

- 6-hourly observations from the above 223 stations (1936-1965), and

- 3-hourly observations from the above 223 stations (1966-1983 ${ }^{1}$ ).

The Carbon Dioxide Information Analysis Center (CDIAC), through a cooperative agreement with NCDC, has packaged and made available to the public the first two of the databases referred to above. The monthly mean temperature data from 243 stations (1891-1988) are included in the Global Historical Climatology Network database (Vose et al. 1992); the daily temperature and precipitation data from 223 stations (1881-1989) are documented in Razuvaev et al. (1993). The purpose of this document is to make available the 6- and 3-hourly observations from this 223-station network. These hourly data represent a wealth of meteorological information for a large and climatologically important part of the earth's land area and are described in the following sections.

\section{DESCRIPTION OF THE DATABASE}

The data records contained in this numeric data package (NDP) include 24 types of meteorological observations from each of the 223 U.S.S.R. stations. These observations appear in each record of the database in the order given below.

- Relative humidity

- Water vapor pressure

- Sea level pressure

- Humidity deficit

- Pressure tendency characteristic

- Pressure tendency value

- Horizontal visibility

- Height of cloud base

- Dew point temperature

- Ground state (description of the state of the ground surface)

${ }^{1}$ All records extend at least through 1983; some extend through 1984,1985 , or 1986. 
- Total cloud amount

- Low-cloud amount

- Wind direction

- Wind speed

- Precipitation amount

- Air pressure at station level

- Near-surface air temperature

- Soil surface temperature

- Past weather

- Present weather

- Atmospheric phenomena

- High-level cloud type

- Mid-level cloud type

- Low-level cloud type

- Characteristic of wind irregularity (only present in 6-hourly observations)

Detailed descriptions of all variables are presented in Part 2. Observations of the last variable in the above list-characteristic of wind irregularity-are only present in the 6-hourly data, which run through 1965. Observations of all other variables are, for the most part, present throughout each station's record. Each record of the database contains entries for all variables at a specific observation hour. (Sample records are shown in Sect. 7, Table 8.) Over the period 1936-65 observations were carried out at 0100, 0700, 1300, and 1900 Local Mean Time (LMT). From 1966 through 1986, observations were made at 0000, 0300, 0600, 0900, $1200,1500,1800$, and 2100 Moscow Legal Time (MLT). In the version of the database presented here, times of observation have been converted to Greenwich Mean Time (GMT) ( $3 \mathrm{~h}$ earlier than MLT); the GMTs of observations vary with station as a function of time zone (longitude). In converting LMT to GMT each station had to be assigned a specific time zone. For a small number of stations there was some uncertainty involved in this; however, the potential error is no more than $1 \mathrm{~h}$ in any case.

Not all stations have data for 1936-86; some station records begin after 1936, some have gaps ranging from one month to several years, and most extend only through 1983 or 1984. An inventory of the 223-station network-including each station's name, World Meteorological Organization (WMO) station number, latitude, longitude, elevation above sea level, and beginning and ending years of record-is given in Table 1. Stations with gaps in their period of record are identified in Table 1, with these gaps presented in detail in Table 2. A map showing the locations of all 223 stations is presented in Fig. 1. 
Table 1. Inventory of stations in the 223-station U.S.S.R. network

\begin{tabular}{|c|c|c|c|c|c|c|c|}
\hline $\begin{array}{l}\text { Ref. } \\
\text { No. }\end{array}$ & $\begin{array}{l}\text { WMO } \\
\text { No. }\end{array}$ & Station Name & $\begin{array}{l}\text { Lat. } \\
\left({ }^{\circ} \mathrm{N}\right)\end{array}$ & $\begin{array}{l}\text { Long. } \\
\left({ }^{\circ} \mathrm{E}\right)\end{array}$ & $\begin{array}{l}\text { Elev. } \\
\text { (m) }\end{array}$ & $\begin{array}{l}\text { Beginning } \\
\text { month/year }\end{array}$ & $\begin{array}{c}\text { Ending } \\
\text { month/year }\end{array}$ \\
\hline 1 & 20674 & OSTROV DIKSON & 73.50 & 80.40 & 42.0 & $01 / 1936$ & $12 / 1984$ \\
\hline 2 & $20891^{b}$ & HATANGA & 71.98 & 102.47 & 30.0 & $01 / 1936$ & $12 / 1984$ \\
\hline 3 & $21946^{b}$ & COKURDAH & 70.62 & 147.88 & 0.0 & $08 / 1944$ & $12 / 1984$ \\
\hline 4 & $21982^{b}$ & OSTROV VRANGELJA & 70.97 & 181.63 & 2.0 & $01 / 1936$ & $12 / 1984$ \\
\hline 5 & 22113 & MURMANSK & 68.97 & 33.05 & 57.0 & $01 / 1936$ & $12 / 1984$ \\
\hline 6 & 22217 & KANDALAKSA & 67.13 & 32.43 & 26.0 & $01 / 1936$ & $12 / 1984$ \\
\hline 7 & 22522 & KEM'-PORT & 64.98 & 34.7 & 7.3 & $01 / 1936$ & $12 / 1983$ \\
\hline 8 & 22550 & ARHANGEL'SK & 64.58 & 40.50 & 8.0 & $01 / 1936$ & $12 / 1983$ \\
\hline 9 & 22583 & KOJNAS & 64.75 & 47.65 & 63.0 & $01 / 1936$ & $12 / 1983$ \\
\hline 10 & $22602^{b}$ & REBOLY & 63.82 & 30.82 & 179.0 & $02 / 1936$ & $12 / 1983$ \\
\hline 11 & 22641 & ONEGA & 63.90 & 38.12 & 11.0 & $01 / 1936$ & $12 / 1983$ \\
\hline 12 & 22802 & SORTOVALA & 61.72 & 30.72 & 17.0 & $01 / 1945$ & $12 / 1983$ \\
\hline 13 & $22820^{b}$ & PETROZAVODSK & 61.82 & 34.27 & 110.0 & $01 / 1936$ & $12 / 1983$ \\
\hline 14 & 22837 & VYTEGRA & 61.02 & 36.45 & 55.0 & $01 / 1936$ & $12 / 1983$ \\
\hline 15 & 22887 & KOTLAS & 61.23 & 46.63 & 56.0 & $01 / 1936$ & $12 / 1983$ \\
\hline 16 & $23146^{b}$ & MYS KAMENNYJ & 68.47 & 73.60 & 2.0 & $03 / 1950$ & $12 / 1984$ \\
\hline 17 & 23205 & NAR'JAN-MAR & 67.65 & 53.02 & 5.0 & $11 / 1947$ & $12 / 1983$ \\
\hline 18 & 23219 & HOSEDA-HARD & 67.08 & 59.38 & 82.0 & $01 / 1936$ & $12 / 1983$ \\
\hline 19 & 23405 & UST'-CIL'MA & 65.45 & 52.17 & 72.0 & $01 / 1936$ & $12 / 1983$ \\
\hline 20 & 23418 & PECORA & 65.12 & 57.10 & 54.5 & $09 / 1943$ & $12 / 1983$ \\
\hline 21 & 23472 & TURUHANSK & 65.78 & 87.95 & 37.0 & $01 / 1936$ & $12 / 1984$ \\
\hline 22 & 23631 & BEREZOVO & 63.93 & 65.05 & 27.0 & $01 / 1936$ & $12 / 1984$ \\
\hline 23 & 23711 & TROICKO-PECERSKOE & 62.70 & 56.20 & 135.0 & $01 / 1936$ & $12 / 1983$ \\
\hline 24 & $23724^{b}$ & NJAKSIMVOL & 62.43 & 60.87 & 50.0 & $01 / 1936$ & $12 / 1984$ \\
\hline 25 & $23804^{b}$ & SYKTYVKAR & 61.67 & 50.85 & 96.0 & $01 / 1950$ & $12 / 1983$ \\
\hline 26 & 23849 & SURGUT & 61.25 & 73.50 & 44.0 & $01 / 1936$ & $09 / 1984$ \\
\hline 27 & $23884^{b}$ & BOR & 61.60 & 90.00 & 62.0 & $01 / 1936$ & $12 / 1984$ \\
\hline 28 & $23891^{b}$ & BAJKIT & 61.67 & 96.37 & 256.0 & $01 / 1936$ & $12 / 1984$ \\
\hline 29 & 23921 & IVDEL' & 60.68 & 60.43 & 93.0 & $01 / 1936$ & $12 / 1984$ \\
\hline 30 & $23933^{b}$ & HANTY-MANSIJSK & 60.97 & 69.07 & 45.0 & $01 / 1936$ & $12 / 1984$ \\
\hline 31 & 23955 & ALEKSANDROVSKOE & 60.43 & 77.87 & 47.0 & $01 / 1936$ & $12 / 1984$ \\
\hline 32 & $24125^{b}$ & OLENEK & 68.50 & 112.43 & 216.5 & $01 / 1936$ & $12 / 1984$ \\
\hline 33 & $24266^{b}$ & VERHOJANSK & 67.55 & 133.38 & 136.0 & $01 / 1936$ & $12 / 1984$ \\
\hline 34 & $24343^{b}$ & ZIGANSK & 66.77 & 123.40 & 88.0 & $02 / 1936$ & $12 / 1984$ \\
\hline 35 & 24507 & TURA & 64.17 & 100.07 & 188.0 & $01 / 1936$ & $12 / 1984$ \\
\hline 36 & 24641 & VILJUJSK & 63.77 & 121.62 & 110.8 & $01 / 1936$ & $12 / 1984$ \\
\hline 37 & 24688 & OJMJAKON & 63.27 & 143.15 & 740.0 & $01 / 1943$ & $12 / 1984$ \\
\hline 38 & 24738 & SUNTAR & 62.15 & 117.65 & 131.0 & $02 / 1936$ & $12 / 1984$ \\
\hline 39 & $24817^{b}$ & ERBOGACEN & 61.27 & 108.02 & 284.0 & $03 / 1936$ & $12 / 1984$ \\
\hline 40 & $24908^{b}$ & VANAVARA & 60.33 & 102.27 & 259.0 & $01 / 1936$ & $12 / 1984$ \\
\hline
\end{tabular}


Table 1. (continued)

\begin{tabular}{|c|c|c|c|c|c|c|c|}
\hline $\begin{array}{l}\text { Ref. } \\
\text { No. }{ }^{a}\end{array}$ & $\begin{array}{l}\text { WMO } \\
\text { No. }\end{array}$ & Station Name & $\begin{array}{l}\text { Lat. } \\
\left({ }^{\circ} \mathrm{N}\right)\end{array}$ & $\begin{array}{l}\text { Long. } \\
\left({ }^{\circ} \mathrm{E}\right)\end{array}$ & $\begin{array}{l}\text { Elev. } \\
(\mathrm{m})\end{array}$ & $\begin{array}{l}\text { Beginning } \\
\text { month/year }\end{array}$ & $\begin{array}{c}\text { Ending } \\
\text { month/year }\end{array}$ \\
\hline 41 & $24944^{b}$ & OLEKMINSK & 60.40 & 120.42 & 223.0 & $01 / 1936$ & $12 / 1984$ \\
\hline 42 & $24951^{b}$ & ISIT' & 60.82 & 125.32 & 117.0 & $01 / 1936$ & $12 / 1984$ \\
\hline 43 & 24959 & JAKUTSK & 62.08 & 129.75 & 98.5 & $01 / 1937$ & $12 / 1984$ \\
\hline 44 & 24966 & UST'-MAJA & 60.38 & 134.45 & 169.0 & $01 / 1936$ & $12 / 1984$ \\
\hline 45 & 25173 & MYS SMIDTA & 68.92 & 180.52 & 3.3 & $01 / 1936$ & $12 / 1984$ \\
\hline 46 & $25551^{b}$ & MARKOVO & 64.68 & 170.42 & 25.0 & $07 / 1937$ & $12 / 1984$ \\
\hline 47 & $25563^{b}$ & ANADYR' & 64.78 & 177.57 & 64.0 & $01 / 1936$ & $12 / 1984$ \\
\hline 48 & $25594^{b}$ & BUHTA PROVIDENJA & 64.43 & 186.77 & 9.0 & $01 / 1936$ & $12 / 1984$ \\
\hline 49 & $25703^{b}$ & SEJMCAN & 62.92 & 152.42 & 206.0 & $01 / 1936$ & $12 / 1984$ \\
\hline 50 & 25744 & KAMENSKOE & 62.48 & 166.22 & 33.0 & $01 / 1950$ & $08 / 1986$ \\
\hline 51 & 25913 & MAGADAN & 59.58 & 150.78 & 115.0 & $01 / 1936$ & $12 / 1984$ \\
\hline 52 & $25954^{b}$ & KORF & 60.35 & 166.00 & 2.0 & $01 / 1936$ & $08 / 1986$ \\
\hline 53 & 26038 & TALLIN & 59.42 & 24.80 & 41.0 & $01 / 1947$ & $12 / 1983$ \\
\hline 54 & 26063 & $\begin{array}{l}\text { ST. PETERSBURG- } \\
\text { TOWN/VILLE }\end{array}$ & 59.97 & 30.30 & 4.0 & $01 / 1936$ & $12 / 1983$ \\
\hline 55 & $26188^{b}$ & VEREB'E & 58.68 & 32.70 & 116.0 & $01 / 1936$ & $12 / 1983$ \\
\hline 56 & 26231 & PJARNU & 58.38 & 24.50 & 1.0 & $08 / 1945$ & $12 / 1983$ \\
\hline 57 & $26258^{b}$ & PSKOV & 57.83 & 28.35 & 42.0 & $01 / 1936$ & $12 / 1983$ \\
\hline 58 & 26406 & LIEPAJA & 56.55 & 21.02 & 4.0 & $06 / 1945$ & $12 / 1983$ \\
\hline 59 & 26422 & RIGA & 56.97 & 24.07 & 7.0 & $01 / 1945$ & $12 / 1983$ \\
\hline 60 & $26477^{b}$ & VELIKIE LUKI & 56.38 & 30.60 & 98.0 & $01 / 1936$ & $12 / 1983$ \\
\hline 61 & 26629 & KAUNAS & 54.88 & 23.88 & 76.0 & $01 / 1943$ & $12 / 1983$ \\
\hline 62 & 26702 & KALININGRAD & 54.70 & 20.62 & 20.0 & $01 / 1947$ & $12 / 1983$ \\
\hline 63 & 26730 & VIL'NJUS & 54.63 & 25.28 & 162.0 & $01 / 1945$ & $12 / 1983$ \\
\hline 64 & 26781 & SMOLENSK & 54.75 & 32.07 & 236.0 & $01 / 1944$ & $12 / 1983$ \\
\hline 65 & $26850^{b}$ & MINSK & 53.87 & 27.53 & 222.0 & $01 / 1939$ & $12 / 1984$ \\
\hline 66 & 27037 & VOLOGDA & 59.28 & 39.87 & 125.0 & $11 / 1983$ & $12 / 1983$ \\
\hline 67 & 27196 & VJATKA & 58.65 & 49.62 & 165.0 & $01 / 1940$ & $12 / 1985$ \\
\hline 68 & 27333 & KOSTROMA & 57.73 & 40.95 & 137.0 & $01 / 1936$ & $12 / 1985$ \\
\hline 69 & 27553 & NIJNIJ NOVGOROD & 56.22 & 43.82 & 161.0 & $01 / 1936$ & $12 / 1985$ \\
\hline 70 & $27595^{b}$ & KAZAN' & 55.78 & 49.18 & 116.0 & $01 / 1936$ & $12 / 1983$ \\
\hline 71 & $27612^{b}$ & MOSKVA & 55.75 & 37.57 & 147.0 & $01 / 1936$ & $12 / 1983$ \\
\hline 72 & 27648 & ELAT'MA & 54.95 & 41.77 & 132.0 & $01 / 1936$ & $12 / 1985$ \\
\hline 73 & $27823^{b}$ & PAVELEC & 53.78 & 39.25 & 209.0 & $01 / 1936$ & $12 / 1985$ \\
\hline 74 & 27947 & TAMBOV & 52.73 & 41.47 & 139.0 & $01 / 1936$ & $12 / 1983$ \\
\hline 75 & 28064 & LEUSI & 59.62 & 65.78 & 72.8 & $01 / 1936$ & $12 / 1984$ \\
\hline 76 & $28138^{b}$ & BISER & 58.52 & 58.85 & 463.0 & $01 / 1936$ & $12 / 1984$ \\
\hline 77 & 28225 & PERM & 58.02 & 56.30 & 169.0 & $01 / 1936$ & $12 / 1984$ \\
\hline 78 & $28275^{b}$ & TOBOL'SK & 58.15 & 68.18 & 48.5 & $01 / 1936$ & $12 / 1984$ \\
\hline 79 & 28411 & IZEVSK & 56.82 & 53.27 & 155.0 & $01 / 1958$ & $12 / 1985$ \\
\hline 80 & 28434 & KRASNOUFIMSK & 56.62 & 57.75 & 20.6 & $01 / 1936$ & $12 / 1984$ \\
\hline
\end{tabular}


Table 1. (continued)

\begin{tabular}{|c|c|c|c|c|c|c|c|}
\hline $\begin{array}{l}\text { Ref. } \\
\text { No. }^{a}\end{array}$ & $\begin{array}{l}\text { WMO } \\
\text { No. }\end{array}$ & Station Name & $\begin{array}{l}\text { Lat. } \\
\left({ }^{\circ} \mathrm{N}\right)\end{array}$ & $\begin{array}{l}\text { Long. } \\
\left({ }^{\circ} \mathrm{E}\right)\end{array}$ & $\begin{array}{l}\text { Elev. } \\
\text { (m) }\end{array}$ & $\begin{array}{l}\text { Beginning } \\
\text { month/year }\end{array}$ & $\begin{array}{c}\text { Ending } \\
\text { month/year }\end{array}$ \\
\hline 81 & $28440^{b}$ & EKATERINBURG & 56.80 & 60.63 & 282.0 & $01 / 1936$ & $12 / 1984$ \\
\hline 82 & $28493^{b}$ & TARA & 56.90 & 74.38 & 73.0 & $01 / 1936$ & $12 / 1983$ \\
\hline 83 & 28661 & KURGAN & 55.47 & 65.40 & 70.0 & $01 / 1936$ & $12 / 1984$ \\
\hline 84 & 28679 & PETROPAVLOVSK & 54.83 & 69.15 & 134.0 & $01 / 1936$ & $12 / 1985$ \\
\hline 85 & 28698 & OMSK & 54.93 & 73.40 & 121.0 & $01 / 1936$ & $12 / 1984$ \\
\hline 86 & 28722 & UFA & 54.75 & 56.00 & 104.0 & $01 / 1936$ & $12 / 1984$ \\
\hline 87 & 28900 & SAMARA, BEZENCUK & 53.25 & 50.45 & 137.0 & $01 / 1936$ & $12 / 1983$ \\
\hline 88 & 28952 & KUSTANAJ & 53.22 & 63.62 & 169.0 & $01 / 1936$ & $12 / 1985$ \\
\hline 89 & 29231 & KOLPASEV & 58.30 & 82.90 & 80.0 & $01 / 1936$ & $12 / 1984$ \\
\hline 90 & 29263 & ENISEJSK & 58.45 & 92.15 & 77.0 & $01 / 1936$ & $12 / 1984$ \\
\hline 91 & $29282^{b}$ & BOGUCANY & 58.42 & 97.40 & 134.0 & $01 / 1936$ & $12 / 1984$ \\
\hline 92 & 29430 & TOMSK & 56.43 & 84.97 & 137.0 & $01 / 1936$ & $12 / 1984$ \\
\hline 93 & 29574 & KRASNOJARSK & 56.00 & 92.88 & 274.0 & $01 / 1936$ & $12 / 1984$ \\
\hline 94 & 29612 & BARABINSK & 55.37 & 78.40 & 120.0 & $01 / 1936$ & $12 / 1984$ \\
\hline 95 & 29698 & NIZNE-UDINSK & 54.88 & 99.03 & 410.0 & $01 / 1940$ & $12 / 1984$ \\
\hline 96 & 29807 & IRTYSSK & 53.35 & 75.45 & 93.0 & $01 / 1936$ & $12 / 1985$ \\
\hline 97 & 29838 & BARNAUL & 53.33 & 83.70 & 153.0 & $01 / 1959$ & $12 / 1984$ \\
\hline 98 & 29866 & MINUSINSK & 53.70 & 91.70 & 251.0 & $01 / 1936$ & $12 / 1984$ \\
\hline 99 & 30054 & VITIM & 59.45 & 112.58 & 186.3 & $01 / 1936$ & $12 / 1984$ \\
\hline 100 & $30230^{b}$ & KIRENSK & 57.77 & 108.12 & 256.0 & $01 / 1936$ & $12 / 1984$ \\
\hline 101 & 30253 & BODAJBO & 57.85 & 114.20 & 278.0 & $01 / 1936$ & $12 / 1984$ \\
\hline 102 & $30372^{b}$ & CARA & 56.92 & 118.37 & 708.0 & $06 / 1938$ & $12 / 1984$ \\
\hline 103 & $30393^{b}$ & CUL'MAN & 56.83 & 124.87 & 843.9 & $01 / 1936$ & $12 / 1984$ \\
\hline 104 & $30521^{b}$ & ZIGALOVO & 54.80 & 105.17 & 426.0 & $08 / 1937$ & $12 / 1984$ \\
\hline 105 & 30555 & TROICKIJ PRIISK & 54.62 & 113.13 & 1315.0 & $03 / 1938$ & $12 / 1984$ \\
\hline 106 & 30636 & BARGUZIN & 53.62 & 109.63 & 488.0 & $01 / 1936$ & $12 / 1984$ \\
\hline 107 & 30673 & MOGOCA & 53.73 & 119.78 & 624.0 & $01 / 1936$ & $12 / 1984$ \\
\hline 108 & 30692 & SKOVORODINO & 54.00 & 123.97 & 397.5 & $01 / 1936$ & $12 / 1984$ \\
\hline 109 & 30710 & IRKUTSK & 52.27 & 104.35 & 467.0 & $01 / 1936$ & $12 / 1984$ \\
\hline 110 & 30758 & CITA & 52.02 & 113.33 & 471.0 & $01 / 1936$ & $12 / 1984$ \\
\hline 111 & 30777 & SRETENSK & 52.27 & 117.70 & 528.0 & $01 / 1936$ & $12 / 1984$ \\
\hline 112 & $30823^{b}$ & ULAN-UDE & 51.80 & 107.43 & 514.0 & $01 / 1936$ & $12 / 1984$ \\
\hline 113 & $30925^{b}$ & KJAHTA & 50.37 & 106.45 & 791.0 & $01 / 1936$ & $12 / 1984$ \\
\hline 114 & $30949^{b}$ & KYRA & 49.57 & 111.97 & 907.0 & $01 / 1936$ & $12 / 1984$ \\
\hline 115 & $30965^{b}$ & BORZJA & 50.38 & 116.52 & 675.0 & $01 / 1936$ & $12 / 1984$ \\
\hline 116 & 31004 & ALDAN & 58.62 & 125.37 & 678.0 & $01 / 1936$ & $12 / 1984$ \\
\hline 117 & 31088 & OHOTSK & 59.37 & 143.20 & 5.0 & $01 / 1936$ & $12 / 1984$ \\
\hline 118 & 31168 & AJAN & 56.45 & 138.15 & 7.0 & $01 / 1936$ & $12 / 1984$ \\
\hline 119 & 31253 & BOMNAK & 54.72 & 128.93 & 357.0 & $01 / 1936$ & $12 / 1984$ \\
\hline 120 & 31329 & EKIMCAN & 53.07 & 132.93 & 540.0 & $01 / 1936$ & $12 / 1984$ \\
\hline
\end{tabular}


Table 1. (continued)

\begin{tabular}{|c|c|c|c|c|c|c|c|}
\hline $\begin{array}{l}\text { Ref. } \\
\text { No. }{ }^{a}\end{array}$ & $\begin{array}{l}\text { WMO } \\
\text { No. }\end{array}$ & Station Name & $\begin{array}{l}\text { Lat. } \\
\left({ }^{\circ} \mathrm{N}\right)\end{array}$ & $\begin{array}{l}\text { Long. } \\
\left({ }^{\circ} \mathrm{E}\right)\end{array}$ & $\begin{array}{l}\text { Elev. } \\
(\mathrm{m})\end{array}$ & $\begin{array}{l}\text { Beginning } \\
\text { month/year }\end{array}$ & $\begin{array}{l}\text { Ending } \\
\text { month/year }\end{array}$ \\
\hline 121 & $31369^{b}$ & NIKOLAEVSK-NA-AMURE & 53.15 & 140.70 & 46.0 & $01 / 1936$ & $12 / 1984$ \\
\hline 122 & 31388 & NORSK & 52.35 & 129.92 & 207.0 & $01 / 1936$ & $12 / 1984$ \\
\hline 123 & $31416^{b}$ & IM POLINY OSIPENKO & 52.42 & 136.50 & 71.0 & $01 / 1936$ & $12 / 1984$ \\
\hline 124 & 31510 & BLAGOVESCENSK & 50.27 & 127.50 & 130.0 & $01 / 1936$ & $12 / 1984$ \\
\hline 125 & $31532^{b}$ & CEKUNDA & 50.82 & 132.17 & 271.0 & $01 / 1936$ & $12 / 1984$ \\
\hline 126 & 31594 & ARHARA & 49.42 & 130.08 & 133.0 & $01 / 1936$ & $12 / 1984$ \\
\hline 127 & 31707 & EKATERINO-NIKOL'SKOE & 47.73 & 130.97 & 72.0 & $01 / 1936$ & $12 / 1984$ \\
\hline 128 & 31735 & HABAROVSK & 48.52 & 135.17 & 88.0 & 05/1952 & $12 / 1984$ \\
\hline 129 & $31829^{b}$ & MYS ZOLOTOJ & 47.32 & 138.98 & 27.0 & $01 / 1936$ & $08 / 1986$ \\
\hline 130 & 31873 & DAL'NERECENSK & 45.87 & 133.73 & 97.0 & $10 / 1939$ & $08 / 1986$ \\
\hline 131 & 31909 & TERNEJ & 45.03 & 136.67 & 51.0 & $02 / 1940$ & $12 / 1984$ \\
\hline 132 & 31915 & POGRANICNYJ & 44.40 & 131.38 & 217.0 & $01 / 1936$ & $08 / 1986$ \\
\hline 133 & $31960^{b}$ & VLADIVOSTOK & 43.12 & 131.90 & 183.0 & $01 / 1936$ & $08 / 1986$ \\
\hline 134 & 32061 & $\begin{array}{l}\text { ALEKSANDROVSK- } \\
\text { SAHALINSKIJ }\end{array}$ & 50.90 & 142.17 & 30.0 & $01 / 1936$ & $12 / 1984$ \\
\hline 135 & 32098 & PORONAJSK & 49.22 & 143.10 & 7.0 & $11 / 1946$ & $12 / 1984$ \\
\hline 136 & 32165 & JUZNO-KURIL'SK & 44.02 & 145.82 & 44.0 & $01 / 1947$ & $12 / 1984$ \\
\hline 137 & 32389 & KLJUCI & 56.32 & 160.83 & 28.0 & $01 / 1936$ & $08 / 1986$ \\
\hline 138 & $32411^{b}$ & ICA & 55.70 & 155.63 & 10.0 & $01 / 1936$ & $08 / 1986$ \\
\hline 139 & $32540^{b}$ & $\begin{array}{l}\text { PETROPAVLOVSK- } \\
\text { KAMCATSKIJ }\end{array}$ & 52.97 & 158.75 & -999.9 & $01 / 1936$ & $08 / 1986$ \\
\hline 140 & 32564 & OKTIABR'SKAYA & 52.67 & 156.23 & 6.0 & $01 / 1936$ & $08 / 1986$ \\
\hline 141 & 33008 & BREST & 52.12 & 23.68 & 141.0 & $08 / 1944$ & $12 / 1984$ \\
\hline 142 & 33038 & VASILEVICI & 52.25 & 29.83 & 139.0 & $03 / 1944$ & $12 / 1984$ \\
\hline 143 & $33345^{b}$ & KIEV & 50.40 & 30.45 & 167.0 & $01 / 1936$ & $12 / 1985$ \\
\hline 144 & $33377^{b}$ & LUBNY & 50.02 & 33.00 & 156.0 & $01 / 1936$ & $12 / 1983$ \\
\hline 145 & $33393^{b}$ & L'VOV & 49.82 & 23.95 & 326.0 & $07 / 1940$ & $12 / 1983$ \\
\hline 146 & $33562^{b}$ & VINNICA & 49.23 & 28.47 & 281.0 & $01 / 1936$ & $12 / 1983$ \\
\hline 147 & 33631 & UZGOROD & 48.63 & 22.27 & 115.0 & $05 / 1946$ & $12 / 1983$ \\
\hline 148 & 33658 & CERNOVCY & 48.27 & 25.97 & 239.0 & $03 / 1941$ & $12 / 1983$ \\
\hline 149 & 33815 & KISINEV & 47.02 & 28.87 & 173.0 & $01 / 1945$ & $12 / 1983$ \\
\hline 150 & $33837^{b}$ & ODESSA & 46.48 & 30.63 & 42.0 & $01 / 1936$ & $12 / 1983$ \\
\hline 151 & 33889 & IZMAIL & 45.37 & 28.87 & 28.0 & $01 / 1946$ & $12 / 1983$ \\
\hline 152 & $33910^{b}$ & GENICESK & 46.17 & 34.82 & 14.0 & $01 / 1936$ & $12 / 1983$ \\
\hline 153 & $33915^{b}$ & ASKANIJA-NOVA & 46.45 & 33.88 & 28.0 & $01 / 1936$ & $12 / 1983$ \\
\hline 154 & 33946 & SIMFEROPOL' & 45.02 & 33.98 & 204.0 & $01 / 1955$ & $12 / 1983$ \\
\hline 155 & $33976^{b}$ & FEODOSIJA & 45.03 & 35.38 & 22.0 & $01 / 1936$ & $12 / 1983$ \\
\hline 156 & $33983^{b}$ & KERC' & 45.37 & 36.43 & 32.0 & $01 / 1955$ & $12 / 1983$ \\
\hline 157 & $34009^{b}$ & KURSK & 51.65 & 36.18 & 246.0 & $01 / 1936$ & $12 / 1983$ \\
\hline 158 & $34122^{b}$ & VORONEZ & 51.70 & 39.17 & 147.0 & $03 / 1936$ & $12 / 1983$ \\
\hline 159 & $34139^{b}$ & KAMENNAJA STEP' & 51.05 & 40.70 & 193.0 & $01 / 1940$ & $12 / 1983$ \\
\hline 160 & $34163^{b}$ & OKTJABR'SKIJ GORODOK & 51.63 & 45.45 & 202.0 & $01 / 1936$ & $12 / 1983$ \\
\hline
\end{tabular}


Table 1. (continued)

\begin{tabular}{|c|c|c|c|c|c|c|c|}
\hline $\begin{array}{l}\text { Ref. } \\
\text { No. }{ }^{a}\end{array}$ & $\begin{array}{l}\text { WMO } \\
\text { No. }\end{array}$ & Station Name & $\begin{array}{l}\text { Lat. } \\
\left({ }^{\circ} \mathrm{N}\right)\end{array}$ & $\begin{array}{l}\text { Long. } \\
\left({ }^{\circ} \mathrm{E}\right)\end{array}$ & $\begin{array}{l}\text { Elev. } \\
\text { (m) }\end{array}$ & $\begin{array}{l}\text { Beginning } \\
\text { month/year }\end{array}$ & $\begin{array}{c}\text { Ending } \\
\text { month/year }\end{array}$ \\
\hline 161 & $34172^{b}$ & SARATOV & 51.57 & 46.03 & 126.0 & $01 / 1936$ & $12 / 1983$ \\
\hline 162 & $34300^{b}$ & HAR'KOV & 49.93 & 36.28 & 147.0 & $01 / 1936$ & $12 / 1983$ \\
\hline 163 & $34391^{b}$ & ALEKSANDROV-GAJ & 50.15 & 48.55 & 23.0 & $01 / 1936$ & $12 / 1983$ \\
\hline 164 & $34524^{b}$ & DEBAL'CEVO & 48.35 & 38.43 & 334.0 & $01 / 1936$ & $12 / 1983$ \\
\hline 165 & $34646^{b}$ & VOLGODONSK & 47.73 & 42.25 & 64.0 & $01 / 1936$ & $12 / 1983$ \\
\hline 166 & $34731^{b}$ & ROSTOV-NA-DONU & 47.25 & 39.82 & 66.0 & $01 / 1936$ & $12 / 1983$ \\
\hline 167 & $34747^{b}$ & CELINA & 46.55 & 41.05 & 111.0 & $01 / 1936$ & $12 / 1983$ \\
\hline 168 & 34824 & PRIMORSKO-AHTARSK & 46.03 & 38.15 & 3.0 & $01 / 1959$ & $12 / 1983$ \\
\hline 169 & 34861 & ELISTA & 46.32 & 44.30 & 151.0 & $01 / 1936$ & $12 / 1983$ \\
\hline 170 & $34880^{b}$ & ASTRAHAN' & 46.27 & 48.03 & -22.0 & $01 / 1936$ & $12 / 1983$ \\
\hline 171 & 35078 & ATBASAR & 51.82 & 68.37 & 303.0 & $01 / 1936$ & $12 / 1985$ \\
\hline 172 & $35108^{b}$ & URAL'SK & 51.25 & 51.40 & 36.0 & $01 / 1936$ & $12 / 1985$ \\
\hline 173 & 35121 & ORENBURG & 51.75 & 55.10 & 115.0 & $01 / 1936$ & $12 / 1983$ \\
\hline 174 & 35133 & ADAMOVKA & 51.52 & 59.95 & 285.0 & $01 / 1936$ & $12 / 1983$ \\
\hline 175 & 35188 & AKMOLINSK & 51.13 & 71.37 & 347.0 & $01 / 1936$ & $12 / 1985$ \\
\hline 176 & 35229 & AKTJUBINSK & 50.28 & 57.15 & 219.0 & $01 / 1936$ & $12 / 1985$ \\
\hline 177 & $35358^{b}$ & TURGAJ & 49.63 & 63.50 & 124.0 & $01 / 1936$ & $12 / 1985$ \\
\hline 178 & 35394 & KARAGANDA & 49.80 & 73.13 & 550.0 & $01 / 1936$ & $12 / 1985$ \\
\hline 179 & $35406^{b}$ & KALMYKOVO & 49.05 & 51.87 & 1.0 & $01 / 1936$ & $12 / 1985$ \\
\hline 180 & $35416^{b}$ & UIL & 49.07 & 54.68 & 88.0 & $01 / 1936$ & $12 / 1985$ \\
\hline 181 & $35542^{b}$ & IRGIZ & 48.62 & 61.27 & 114.0 & $01 / 1936$ & $12 / 1985$ \\
\hline 182 & $35576^{b}$ & KZYL-ZAR & 48.30 & 69.65 & 361.0 & $11 / 1937$ & $12 / 1985$ \\
\hline 183 & 35663 & KARSAKPAJ & 47.83 & 66.75 & 488.0 & $01 / 1936$ & $12 / 1985$ \\
\hline 184 & 35700 & GUR'EV & 47.02 & 51.85 & -24.0 & $01 / 1936$ & $12 / 1985$ \\
\hline 185 & $35746^{b}$ & ARAL'SKOE MORE & 46.78 & 61.67 & 62.0 & $01 / 1936$ & $12 / 1985$ \\
\hline 186 & $35796^{b}$ & BALHAS & 46.90 & 75.00 & 347.0 & $01 / 1936$ & $12 / 1985$ \\
\hline 187 & 36034 & RUBCOVSK & 51.50 & 81.22 & 216.0 & $01 / 1936$ & $12 / 1984$ \\
\hline 188 & $36177^{b}$ & SEMIPALATINSK & 50.35 & 80.25 & 195.0 & $01 / 1936$ & $12 / 1985$ \\
\hline 189 & 36665 & ZAJSAN & 47.47 & 84.92 & 604.0 & $01 / 1936$ & $12 / 1985$ \\
\hline 190 & $36729^{b}$ & UC-ARAL & 46.17 & 80.93 & 397.0 & $01 / 1936$ & $12 / 1985$ \\
\hline 191 & 36859 & PANFILOV & 44.17 & 80.07 & 641.0 & $01 / 1936$ & $12 / 1985$ \\
\hline 192 & 36870 & ALMA-ATA & 43.23 & 76.93 & 847.0 & $01 / 1936$ & $12 / 1985$ \\
\hline 193 & $36974^{b}$ & NARYN & 41.43 & 76.00 & 2039.0 & $01 / 1936$ & $12 / 1984$ \\
\hline 194 & $37031^{b}$ & ARMAVIR & 44.98 & 41.12 & 158.0 & $01 / 1936$ & $12 / 1983$ \\
\hline 195 & $37050^{b}$ & PJATIGORSK & 44.05 & 43.03 & 531.0 & $01 / 1936$ & $12 / 1983$ \\
\hline 196 & $37099^{b}$ & SOCI & 43.58 & 39.72 & 57.0 & $01 / 1936$ & $12 / 1983$ \\
\hline 197 & $37235^{b}$ & GROZNYJ & 43.35 & 45.68 & 123.0 & $08 / 1938$ & $12 / 1983$ \\
\hline 198 & 37385 & SAMTREDIA & 42.18 & 42.37 & 28.0 & $01 / 1936$ & $12 / 1983$ \\
\hline 199 & $37472^{b}$ & MAHACKALA & 43.02 & 47.43 & -21.0 & $01 / 1936$ & $12 / 1983$ \\
\hline 200 & 37549 & TBILISI & 41.68 & 44.95 & 427.0 & $01 / 1936$ & $12 / 1983$ \\
\hline
\end{tabular}


Table 1. (continued)

\begin{tabular}{|c|c|c|c|c|c|c|c|}
\hline $\begin{array}{l}\text { Ref. } \\
\text { No. }^{a}\end{array}$ & $\begin{array}{c}\text { WMO } \\
\text { No. }\end{array}$ & Station Name & $\begin{array}{l}\text { Lat. } \\
\left({ }^{\circ} \mathrm{N}\right)\end{array}$ & $\begin{array}{l}\text { Long. } \\
\left({ }^{\circ} \mathrm{E}\right)\end{array}$ & $\begin{array}{l}\text { Elev. } \\
\text { (m) }\end{array}$ & $\begin{array}{l}\text { Beginning } \\
\text { month/year }\end{array}$ & $\begin{array}{c}\text { Ending } \\
\text { month/year }\end{array}$ \\
\hline 201 & 37686 & GUMRY & 40.78 & 43.83 & 1523.0 & $01 / 1936$ & $12 / 1983$ \\
\hline 202 & 37735 & GYANDJA & 40.72 & 46.42 & 308.0 & $01 / 1936$ & $12 / 1983$ \\
\hline 203 & 37789 & EREVAN & 40.13 & 44.47 & 888.0 & $01 / 1936$ & $12 / 1983$ \\
\hline 204 & 38198 & TURKESTAN & 43.27 & 68.22 & 206.0 & $01 / 1936$ & $12 / 1985$ \\
\hline 205 & 38262 & CIMBAJ & 42.95 & 59.82 & 64.7 & $01 / 1937$ & $12 / 1984$ \\
\hline 206 & 38353 & BISHKEK & 42.83 & 74.58 & 756.0 & $01 / 1939$ & $12 / 1984$ \\
\hline 207 & $38413^{b}$ & TAMDY & 41.73 & 64.62 & 236.0 & $01 / 1936$ & $12 / 1984$ \\
\hline 208 & 38457 & TASKENT & 41.27 & 69.27 & 477.0 & $01 / 1936$ & $12 / 1984$ \\
\hline 209 & $38507^{b}$ & KRASNOVODSK & 40.03 & 52.98 & 89.0 & $01 / 1936$ & $12 / 1984$ \\
\hline 210 & 38599 & LENINABAD & 40.22 & 69.73 & 425.0 & $01 / 1936$ & $12 / 1984$ \\
\hline 211 & 38618 & FERGANA & 40.37 & 71.75 & 577.8 & $01 / 1936$ & $12 / 1984$ \\
\hline 212 & 38687 & CARDZOU & 39.08 & 63.60 & 188.0 & $01 / 1936$ & $12 / 1984$ \\
\hline 213 & 38696 & SAMARKAND & 39.57 & 66.95 & 725.0 & $01 / 1936$ & $12 / 1984$ \\
\hline 214 & $38750^{b}$ & GASAN-KULI & 37.47 & 53.97 & -24.0 & $01 / 1936$ & $12 / 1984$ \\
\hline 215 & 38763 & KIZYL-ARVAT & 38.98 & 56.28 & 97.0 & $01 / 1936$ & $12 / 1984$ \\
\hline 216 & 38836 & DUSANBE & 38.58 & 68.78 & 796.0 & $01 / 1936$ & $12 / 1984$ \\
\hline 217 & $38880^{b}$ & ASHABAD & 37.97 & 58.33 & 227.0 & $06 / 1937$ & $12 / 1984$ \\
\hline 218 & 38895 & BAJRAM-ALI & 37.60 & 62.18 & 240.0 & $01 / 1936$ & $12 / 1984$ \\
\hline 219 & $38927^{b}$ & TERMEZ & 37.23 & 67.27 & 309.0 & $01 / 1936$ & $12 / 1984$ \\
\hline 220 & 38933 & KURGAN-TJUBE & 37.82 & 68.78 & 427.0 & $01 / 1936$ & $12 / 1984$ \\
\hline 221 & $38954^{b}$ & HOROG & 37.50 & 71.50 & 2077.0 & $09 / 1936$ & $12 / 1984$ \\
\hline 222 & $38974^{b}$ & SERAHS & 36.53 & 61.22 & 275.0 & $01 / 1936$ & $12 / 1984$ \\
\hline 223 & $38987^{b}$ & KUSKA & 35.28 & 62.35 & 625.0 & $01 / 1936$ & $12 / 1984$ \\
\hline
\end{tabular}

${ }^{a}$ Reference number, assigned for ease in locating each station on the map shown in Fig. 1.

${ }^{b}$ Station has missing data for at least one month. See Table 2 for details. 
Table 2. Gaps in the periods of record of the 223 U.S.S.R. stations

\begin{tabular}{|c|c|c|c|}
\hline WMO No. & $\begin{array}{l}\text { Month/year range } \\
\text { of gap (inclusive) }\end{array}$ & WMO No. & $\begin{array}{l}\text { Month/year range } \\
\text { of gap (inclusive) }\end{array}$ \\
\hline 20891 & $07 / 1944-06 / 1946$ & 27595 & $01 / 1942-03 / 1943$ \\
\hline 21946 & $08 / 1947-09 / 1947$ & 27612 & $03 / 1941$ \\
\hline 21982 & $10 / 1943$ & & $12 / 1943$ \\
\hline \multirow[t]{5}{*}{22602} & $03 / 1937$ & 27823 & $10 / 1941-01 / 1942$ \\
\hline & $05 / 1937$ & 28138 & $12 / 1955$ \\
\hline & $07 / 1937-08 / 1937$ & 28275 & $04 / 1944$ \\
\hline & $02 / 1940-03 / 1940$ & 28440 & $01 / 1938-12 / 1939$ \\
\hline & $06 / 1941-05 / 1945$ & 28493 & $03 / 1944$ \\
\hline 22820 & $09 / 1941-07 / 1944$ & 29282 & $07 / 1944$ \\
\hline 23146 & $07 / 1959$ & & $04 / 1945$ \\
\hline 23724 & $09 / 1947-11 / 1947$ & 30230 & $10 / 1941$ \\
\hline 23804 & $01 / 1961-03 / 1961$ & & $01 / 1942$ \\
\hline 23884 & $01 / 1958-12 / 1958$ & & $04 / 1943-08 / 1943$ \\
\hline \multirow[t]{2}{*}{23891} & $01 / 1936-01 / 1937$ & & $12 / 1943-01 / 1944$ \\
\hline & $05 / 1937-07 / 1937$ & & $07 / 1944-08 / 1944$ \\
\hline 23933 & $03 / 1960-07 / 1961$ & 30372 & $12 / 1941$ \\
\hline \multirow[t]{3}{*}{24125} & $04 / 1939-08 / 1939$ & 30393 & $08 / 1936$ \\
\hline & $04 / 1945-08 / 1946$ & & $12 / 1936$ \\
\hline & $01 / 1949-03 / 1949$ & & $11 / 1943-03 / 1944$ \\
\hline 24266 & $07 / 1950-09 / 1950$ & & $08 / 1944-11 / 1944$ \\
\hline \multirow[t]{2}{*}{24343} & $02 / 1954$ & 30521 & $11 / 1937-12 / 1937$ \\
\hline & $04 / 1963$ & & $05 / 1938$ \\
\hline \multirow[t]{2}{*}{24817} & $01 / 1937-05 / 1938$ & & $12 / 1946$ \\
\hline & $05 / 1944$ & 30823 & $08 / 1942-09 / 1947$ \\
\hline \multirow[t]{2}{*}{24908} & $04 / 1938-08 / 1938$ & 30925 & $11 / 1944-02 / 1945$ \\
\hline & $05 / 1948$ & & $07 / 1946$ \\
\hline 24944 & $01 / 1942$ & & $03 / 1947$ \\
\hline \multirow[t]{2}{*}{24951} & $04 / 1943-05 / 1943$ & 30949 & $03 / 1936$ \\
\hline & $10 / 1943-12 / 1945$ & & $12 / 1937$ \\
\hline \multirow[t]{3}{*}{25551} & $09 / 1937$ & & $01 / 1942-03 / 1942$ \\
\hline & $07 / 1938-08 / 1938$ & & $08 / 1942$ \\
\hline & $05 / 1940-12 / 1943$ & & $11 / 1942-12 / 1942$ \\
\hline \multirow[t]{2}{*}{25563} & $12 / 1936$ & & $05 / 1943$ \\
\hline & $07 / 1949-08 / 1949$ & & $08 / 1943-04 / 1944$ \\
\hline 25594 & $03 / 1938-03 / 1939$ & & $03 / 1945-10 / 1945$ \\
\hline 25703 & $06 / 1938-12 / 1942$ & & $12 / 1945$ \\
\hline \multirow[t]{2}{*}{25954} & $02 / 1946$ & & $02 / 1946-06 / 1946$ \\
\hline & $08 / 1946-04 / 1947$ & 30965 & $06 / 1939$ \\
\hline 26188 & $08 / 1941-12 / 1943$ & & $08 / 1939$ \\
\hline 26258 & $07 / 1941-08 / 1944$ & & $07 / 1951$ \\
\hline 26477 & $06 / 1941-02 / 1946$ & & \\
\hline 26850 & $04 / 1941-07 / 1944$ & & \\
\hline
\end{tabular}


Table 2. (continued)

\begin{tabular}{|c|c|c|c|}
\hline WMO No. & $\begin{array}{l}\text { Month/year range } \\
\text { of gap (inclusive) }\end{array}$ & WMO No. & $\begin{array}{l}\text { Month/year range } \\
\text { of gap (inclusive) }\end{array}$ \\
\hline \multirow[t]{2}{*}{31369} & $01 / 1945-07 / 1945$ & 34172 & $09 / 1945$ \\
\hline & $01 / 1948$ & 34300 & $09 / 1941-12 / 1945$ \\
\hline 31416 & $05 / 1939-06 / 1939$ & 34391 & $06 / 1960-10 / 1960$ \\
\hline 31532 & $03 / 1936-04 / 1936$ & & $04 / 1961-10 / 1961$ \\
\hline 31829 & $10 / 1937-04 / 1938$ & & $04 / 1962-10 / 1962$ \\
\hline \multirow[t]{3}{*}{31960} & $04 / 1944-01 / 1947$ & & $04 / 1963-10 / 1963$ \\
\hline & $04 / 1944-01 / 1947$ & & $04 / 1964-10 / 1964$ \\
\hline & $01 / 1960-10 / 1962$ & & $04 / 1965-10 / 1965$ \\
\hline \multirow[t]{4}{*}{32411} & $05 / 1937-06 / 1937$ & 34524 & $09 / 1941-11 / 1943$ \\
\hline & $12 / 1948-02 / 1949$ & 34646 & $07 / 1955-03 / 1957$ \\
\hline & $04 / 1950$ & 34731 & $10 / 1941-12 / 1941$ \\
\hline & $08 / 1953-09 / 1953$ & & $07 / 1942-02 / 1943$ \\
\hline 32540 & $12 / 1937$ & & $09 / 1943-12 / 1943$ \\
\hline \multirow[t]{3}{*}{33345} & $01 / 1938$ & 34747 & $07 / 1942-03 / 1943$ \\
\hline & $09 / 1941-12 / 1941$ & 34880 & $03 / 1938$ \\
\hline & $09 / 1943-12 / 1943$ & & $09 / 1946$ \\
\hline \multirow[t]{4}{*}{33377} & $01 / 1941-02 / 1941$ & 35108 & $02 / 1942-03 / 1942$ \\
\hline & $09 / 1941-04 / 1943$ & 35358 & $11 / 1937-12 / 1939$ \\
\hline & $06 / 1943-07 / 1943$ & & $02 / 1939$ \\
\hline & $09 / 1943-10 / 1943$ & & $08 / 1950-12 / 1953$ \\
\hline 33393 & $06 / 1941-11 / 1944$ & & $05 / 1954-12 / 1954$ \\
\hline \multirow[t]{5}{*}{33562} & $01 / 1941-02 / 1941$ & 35406 & $05 / 1943-06 / 1943$ \\
\hline & $07 / 1941-09 / 1941$ & & $11 / 1944-12 / 1944$ \\
\hline & $01 / 1942-08 / 1943$ & & $02 / 1945-07 / 1946$ \\
\hline & $01 / 1944$ & & $05 / 1961$ \\
\hline & $03 / 1944$ & 35416 & $09 / 1942$ \\
\hline 33837 & $10 / 1941-12 / 1943$ & 35542 & $10 / 1940$ \\
\hline \multirow[t]{2}{*}{33910} & $09 / 1941-07 / 1943$ & & $08 / 1947-09 / 1947$ \\
\hline & $09 / 1943-01 / 1944$ & & $11 / 1951$ \\
\hline \multirow[t]{3}{*}{33915} & $08 / 1941-09 / 1941$ & 35576 & $07 / 1945$ \\
\hline & $11 / 1941-12 / 1941$ & & $01 / 1946-03 / 1946$ \\
\hline & $10 / 1943-02 / 1944$ & 35746 & $10 / 1938$ \\
\hline \multirow[t]{3}{*}{33976} & $10 / 1941-12 / 1942$ & 35796 & $02 / 1936$ \\
\hline & $02 / 1943$ & 36177 & $08 / 1951$ \\
\hline & $10 / 1943-04 / 1944$ & & $09 / 1954-10 / 1954$ \\
\hline 34009 & $02 / 1943$ & & $10 / 1955-11 / 1955$ \\
\hline 34122 & $08 / 1941$ & & $08 / 1956-09 / 1956$ \\
\hline \multirow[t]{2}{*}{34139} & $08 / 1941-12 / 1941$ & 36729 & $12 / 1938-03 / 1939$ \\
\hline & $06 / 1942-08 / 1942$ & & $02 / 1943-03 / 1943$ \\
\hline \multirow[t]{2}{*}{34163} & $01 / 1943-02 / 1944$ & & $09 / 1945$ \\
\hline & $03 / 1948$ & & $05 / 1947$ \\
\hline
\end{tabular}


Table 2. (continued)

\begin{tabular}{ll|cl}
\hline WMO No. $\quad \begin{array}{l}\text { Month/year range } \\
\text { of gap (inclusive) }\end{array}$ & WMO No. & $\begin{array}{l}\text { Month/year range } \\
\text { of gap (inclusive) }\end{array}$ \\
\hline 36974 & $10 / 1938$ & 38507 & $01 / 1946-12 / 1946$ \\
37031 & $07 / 1942-01 / 1943$ & & $06 / 1958-09 / 1960$ \\
37050 & $08 / 1942-02 / 1943$ & 38750 & $05 / 1964-07 / 1964$ \\
& $03 / 1948$ & 38880 & $01 / 1945-12 / 1950$ \\
37099 & $07 / 1942-12 / 1944$ & 38927 & $01 / 1946-12 / 1947$ \\
37235 & $08 / 1942$ & 38954 & $12 / 1937$ \\
37472 & $01 / 1941$ & 38974 & $10 / 1937-12 / 1937$ \\
& $12 / 1946$ & & $10 / 1938$ \\
38413 & $02 / 1943$ & 38987 & $12 / 1938$ \\
& & & $07 / 1941$ \\
& & & \\
\hline
\end{tabular}




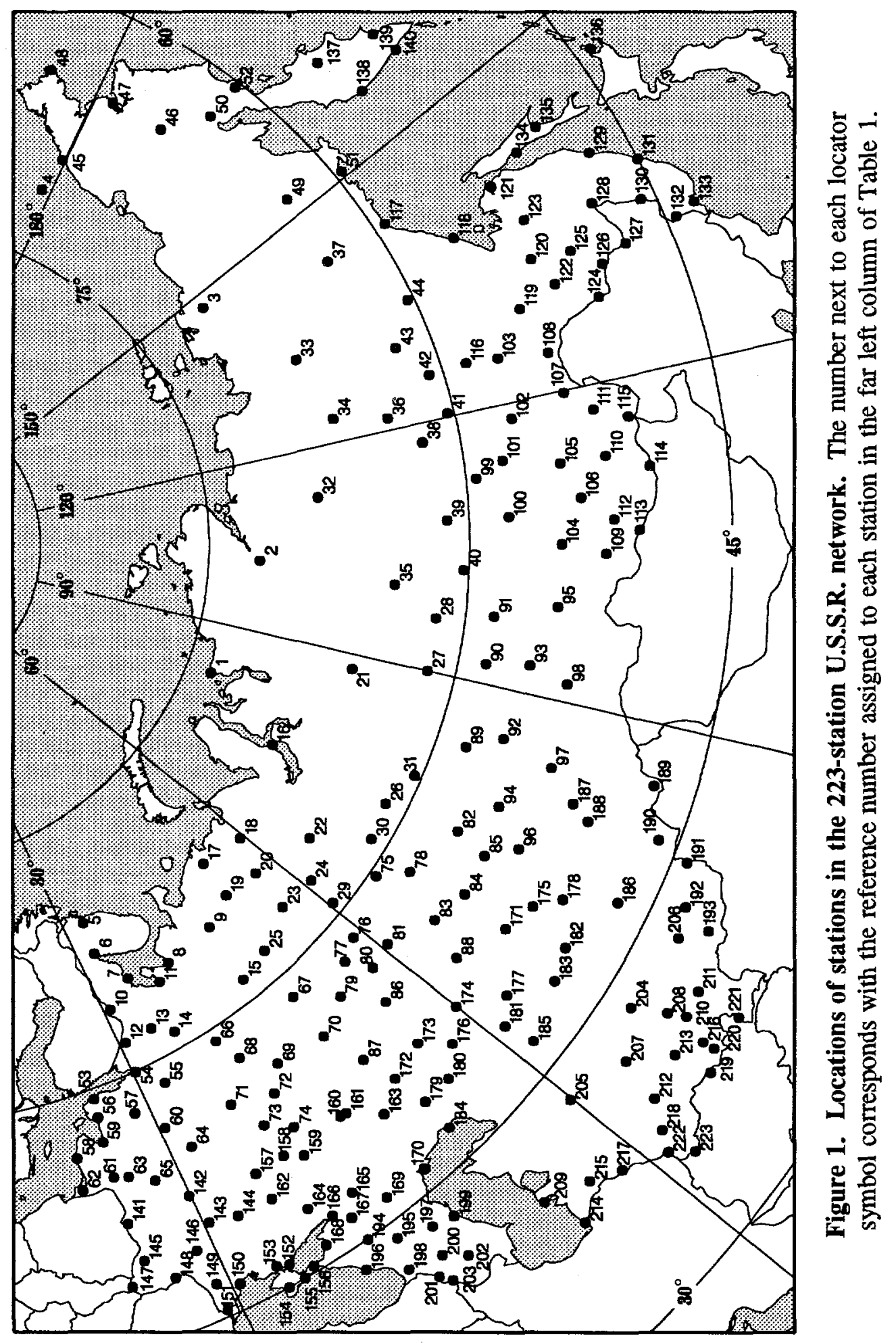




\section{CDIAC QUALITY ASSURANCE CHECKS}

An important part of the data packaging process at CDIAC involves the quality assurance (QA) of data before distribution. Data received by CDIAC are rarely in a condition that would permit immediate distribution, regardless of their source. To guarantee data of the highest possible quality, CDIAC performs extensive QA checks, examining the data for completeness, reasonableness, and accuracy.

Some basic data checks had been performed by RIHMI-WDC and NCDC prior to the arrival of the data at CDIAC. Extensive documentation pertaining to the units, acceptable ranges, and coding of variables in the database was provided by RIHMI-WDC to CDIAC. This information provided a basis for data checks performed by CDIAC and comprises the bulk of the database description presented in Part 2. Descriptions of data checks performed and a few general comments on findings are presented below.

- Station numbers in data files were verified through comparison with station inventory information provided in a separate file by RIHMI-WDC.

- Dates in data records were checked. Checks included

- ensuring that the year of all 6-hourly observations was $\geq 1936$ and $\leq 1965$ and that the year of all 3-hourly observations was $\geq 1966$ and $\leq 1986$;

- ensuring that the month, day, and hour of each observation contained reasonable values (e.g., all months were checked for the correct number of days, and the hour of each observation was checked to make sure it corresponded with the hourly increments prescribed in the RIHMI-WDC documentation);

- ensuring that data records were sorted chronologically.

- Gaps were searched for in the period of record of each station. This included

- looking for missing individual hourly entries. Where these were discovered, an entry with the appropriate time was inserted that included missing indicators (composed of "9"s) for all meteorological variables. This was done to maintain hour-to-hour continuity (i.e., four and eight entries per day, for the 6- and 3-hourly observations, respectively);

- checking for missing days in each month that had at least partial data for the month (hourly entries with missing data codes were inserted for the few missing days that were found);

- checking for missing months or years of data. This type of occurrence is fairly common in the database. Records with missing data values were not inserted where these larger-scale gaps occurred; rather, these occurrences have been detailed in Table 2.

- Values for each variable were checked to make sure they were within the acceptable and reasonable ranges prescribed in the RIHMI-WDC documentation. When values outside these ranges were discovered, the complement and/or quality flags associated with that particular variable were set to 9 to indicate suspect data. (See Sect. 6 for details on ranges and data flags.) 
Flags determined to be invalid based upon RIHMI-WDC documentation were set to 9 to indicate that the associated data value should be interpreted with caution.

\section{HOW TO OBTAIN THE PACKAGE}

The U.S.S.R. 6- and 3-hourly database is available free of charge from CDIAC. The files are available on $8 \mathrm{~mm}$ tape or from CDIAC's anonymous FTP (file transfer protocol) area via the Internet. (Users are asked to contact CDIAC for assistance if neither of these mediums is suited to their particular computing environment.) Obtaining the data from CDIAC's anonymous FTP area requires a computer with FTP software and access to the Internet. A sampling of commands used to obtain the station inventory file from this database is shown below. CDIAC FTP server responses are shown in italics; user entries are bolded. For a full description of commands, contact CDIAC.

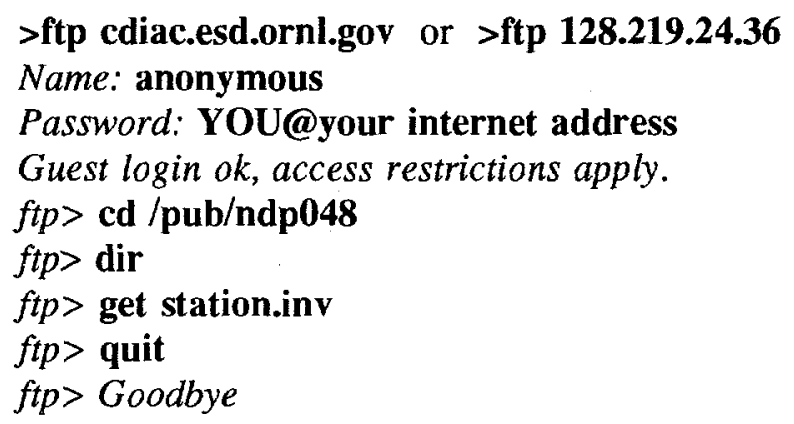

For non-FTP data acquisitions, users may request data from CDIAC using the following information:
Address:
Carbon Dioxide Information Analysis Center
Oak Ridge National Laboratory
P.O. Box 2008
Oak Ridge, Tennessee 37831-6335, U.S.A.

Telephone:

$$
\begin{aligned}
& \text { (615) 574-3645 (Voice) } \\
& \text { (615) 574-2232 (Fax) }
\end{aligned}
$$

Electronic mail: Internet: CDIAC@ORNL.GOV 


\section{REFERENCES}

Razuvaev, V. N., E. G. Apasova, and R. A. Martuganov. 1993. Daily Temperature and Precipitation Data for 223 USSR Stations. ORNL/CDIAC-56, NDP-040. Carbon Dioxide Information Analysis Center, Oak Ridge National Laboratory, Oak Ridge, Tennessee.

Vose, R. S., R. L. Schmoyer, P. M. Steurer, T. C. Peterson, R. Heim, T. R. Karl, and J. K. Eischeid. 1992. The Global Historical Climatology Network: Long-term monthly temperature, precipitation, sea level pressure, and station pressure data. ORNL/CDIAC-53, NDP-041. Carbon Dioxide Information Analysis Center, Oak Ridge National Laboratory, Oak Ridge, Tennessee. 

PART 2

CONTENT AND FORMAT OF DATA FILES 


\section{FILE DESCRIPTIONS}

This section describes the content and format of each of the 40 files that comprise this NDP (Table 3). File names and numbers and brief descriptions of the files are given below.

- NDP048.DES (File 1) describes the details of the database. It contains the text from Sects. 1-7 of this document.

- INVENT.FOR (File 2) contains a FORTRAN program for reading STATION.INV (File 12).

- GAPS.FOR (File 3) contains a FORTRAN program for reading GAPS.DAT (File 13).

- TIMEZONE.FOR (File 4) contains a FORTRAN program for reading TIMEZONE.DAT (File 14).

- HISTORY.FOR (File 5) contains a FORTRAN program for reading STATION.HIS (File 15).

- DATA.FOR (File 6) contains a FORTRAN program for reading USSR01.DATUSSR25.DAT (Files 16-40).

- INVENT.SAS (File 7) contains a SAS ${ }^{\circledR}$ program for reading STATION.INV (File 12).

- GAPS.SAS (File 8) contains a SAS ${ }^{\circledR}$ program for reading GAPS.DAT (File 13).

- TIMEZONE.SAS (File 9) contains a SAS $^{\circledR}$ program for reading TIMEZONE.DAT (File 14).

- HISTORY.SAS (File 10) contains a SAS ${ }^{\circledR}$ program for reading STATION.HIS (File 15).

- DATA.SAS (File 11) contains a SAS ${ }^{\circledast}$ program for reading USSR01.DAT-USSR25.DAT (Files 16-40).

- STATION.INV (File 12) contains the name, WMO number, latitude, longitude, elevation, beginning month and year of record, and ending month and year of record for each of the 223 stations.

- GAPS.DAT (File 13) contains information on stations that have at least one gap at least one month in duration at any time during their period of record.

- TIMEZONE.DAT (File 14) contains the time zone of each of the 223 stations, expressed as the number of time zones (hours) east of GMT (referenced by WMO number). This information may be used for converting observations at each U.S.S.R. station from GMT to LMT.

- STATION.HIS (File 15) contains information on rain gauge replacement dates and information on the date, direction, and distance of any station relocations. 
- USSR01.DAT-USSR25.DAT (Files 16-40) contain the 6- and 3-hourly meteorological observations from the 223 stations. 
Table 3. Size and format information for the NDP files

File number and description
File size

(kB)

118.70

0.42

0.22

0.22

0.36

2.50

0.20

0.12

0.18

1.03

22

80

Logical

records

80

2,524

13

80

80

80

80

80

80

80

80
$S A S^{\oplus}$ program for reading ussr01.dat-ussr25.dat.

Record

length

SAS ${ }^{\star}$ program for reading timezone.dat.

SAS $^{\circledast}$ program for reading station.his.

11. DATA.SAS 
File number and description
File size ${ }^{a}$

contains information on gaps

in stations' periods of record.

14. TIMEZONE.DAT:

contains time zone information for each station. Used for converting GMT to LMT.

15. STATION.HIS:

contains information on rain gauge replacements and station relocations.

16. USSR01.DAT:

contains 6- and 3-hourly data for stations 20674-22583

17. USSR02.DAT:

contains 6- and 3-hourly data

for stations 22602-23219

18. USSR03.DAT:

contains 6- and 3-hourly data

for stations 23405-23884

19. USSR04.DAT:

contains 6- and 3-hourly data for stations 23891-24641

20. USSR05.DAT:

contains 6- and 3-hourly data

for stations 24688-25173

21. USSR06.DAT:

contains 6- and 3-hourly data

for stations 25551-26063

22. USSR07.DAT:

contains 6- and 3-hourly data for stations 26188-26730
(kB)

16.06

5.20

200

25

23.49

810

28

Logical

Record

length

71

2.00

223

8

111,303

869,556

127

103,086

805,364

127

108,499

847,648

127

113,609

887,572

127

112,037

875,296

127

108,403

846,900

127

99,049

773820

127 
File number and description contains 6- and 3-hourly data

for stations $27823-28440$

25. USSR10.DAT:

contains 6- and 3-hourly data for stations 28493-29263

26. USSR11.DAT:

contains 6- and 3-hourly data

for stations 29282-30054

27. USSR12.DAT:

contains 6- and 3-hourly data

for stations 30230-30692

28. USSR13.DAT:

contains 6- and 3-hourly data

for stations $30710-31088$

29. USSR14.DAT:

contains 6- and 3-hourly data for stations 31168-31594

30. USSR15.DAT:

contains 6- and 3-hourly data for stations 31707-32098

31. USSR16.DAT:

contains 6- and 3-hourly data for stations 32165-33377

32. USSR17.DAT:

contains 6- and 3-hourly data for stations 33393-33915

33. USSR18.DAT:

contains 6- and 3-hourly data for stations 33946-34300

34. USSR19.DAT:

contains 6- and 3-hourly data for stations 34391-35078
File size ${ }^{a}$

(kB)

110,294

110,341

862,044

127

Logical

records

Record

length

861,672

127

114,435

894,028

127

109,746

857,396

127

112,845

881,608

127

112,660

880,160

127

113,706

888,332

127

109,230

853,360

127

110,867

866,148

127

101,154

790,268

127

101,576

793,568

127

105,500

824,224

127 
35. USSR20.DAT:

114,889

897,572

contains 6- and 3-hourly data

for stations 35108-35416

36. USSR21.DAT:

116,835

912,780

127

contains 6- and 3-hourly data

for stations 35542-36665

37. USSR22.DAT:

112,486

878,804

127

contains 6- and 3-hourly data

for stations 36729-37385

38. USSR23.DAT:

111,924

874,412

127

contains 6- and 3-hourly data

for stations 37472-38413

39. USSR24.DAT:

113,595

887,468

127

contains 6- and 3-hourly data

for stations 38457-38836

40. USSR25.DAT:

87,210

681,332

127

contains 6- and 3-hourly data

for stations 38880-38987

${ }^{a}$ Actual size of files in non-compressed form. Files in CDIAC's anonymous ftp area are compressed and are $-1 / 4$ this size. 
NDP048.DES (FILE 1)

This file provides a detailed description of the database. It is an electronic version of Sects. 1-7 of this document (figures excluded).

\section{INVENT.FOR (FILE 2)}

This file contains the FORTRAN program to read station.inv (File 12). The following is a listing of the program.

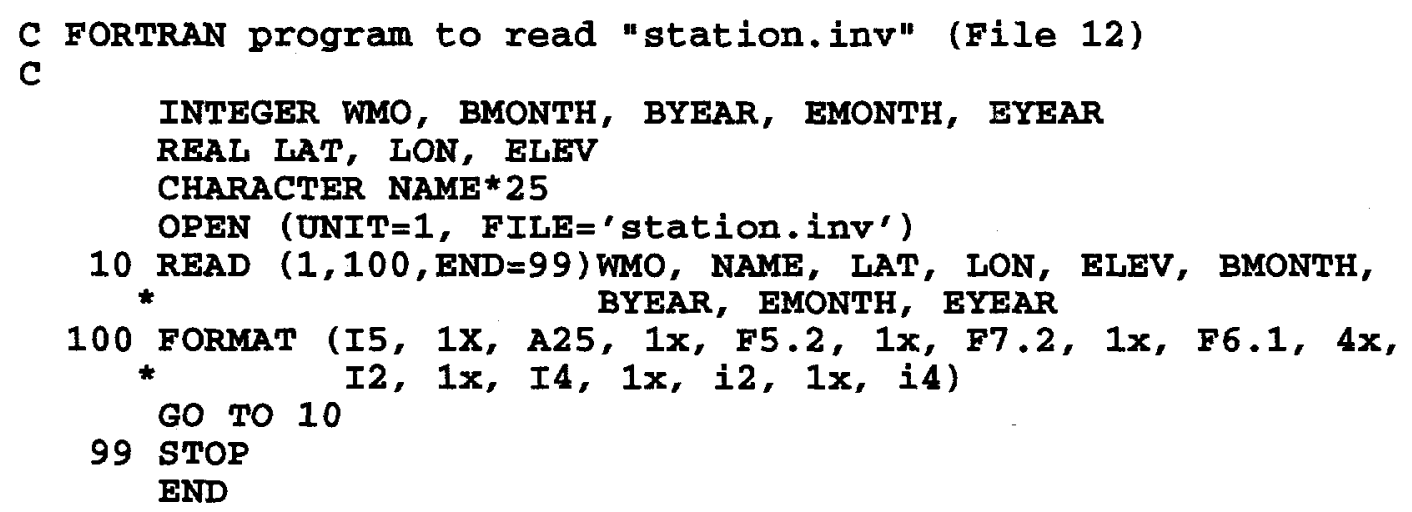

\section{GAPS.FOR (FILE 3)}

This file contains the FORTRAN program to read gaps.dat (File 13). The following is a listing of the program.

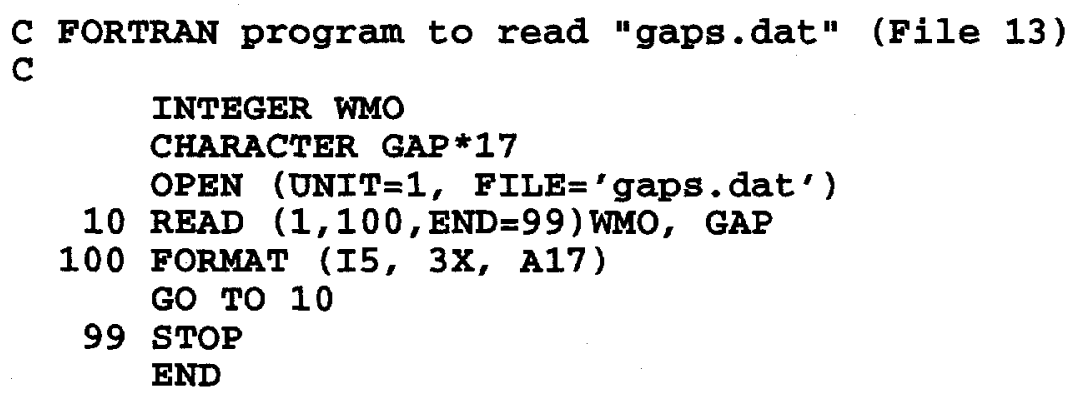

\section{TIMEZONE.FOR (FILE 4)}

This file contains the FORTRAN program to read timezone.dat (File 14). The following is a listing of the program.

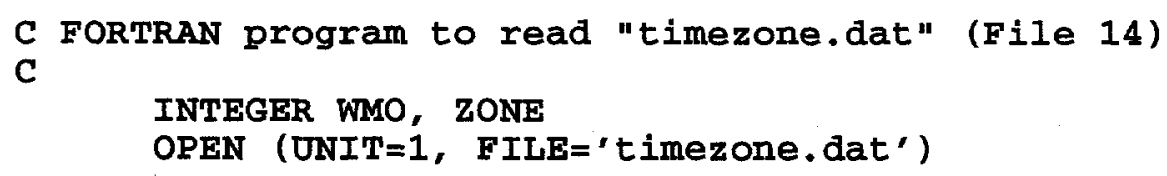


10 READ $(1,100$, END=99) WMO, ZONE

100 FORMAT (I5, 1X, I2)

99 STOP

GO TO 10

END

\section{HISTORY.FOR (FILE 5)}

This file contains the FORTRAN program to read station.his (File 15). The following is a listing of the program.

C FORTRAN program to read "station.his" (File 15)

C

INTEGER WMO, YEAR, MONTH, DAY

CHARACTER TYPE* 4, DIST*2, DIRECT*3

OPEN (UNIT=1, FILE='station.his')

10 READ (1,100, END=99) WMO, TYPE, YEAR, MONTH, DAY, DIST, * DIRECT

100 FORMAT $(I 5,1 \mathrm{X}, \mathrm{A4}, 1 \mathrm{X}, \mathrm{A4}, 1 \mathrm{X}, \mathrm{I2}, 1 \mathrm{X}, \mathrm{I2}, 1 \mathrm{X}, \mathrm{A2}, 1 \mathrm{X}, \mathrm{A3})$ GO TO 10

99 STOP

END

\section{DATA.FOR (FILE 6)}

This file contains a FORTRAN program for reading any of the U.S.S.R. 6- and 3-hourly data files (ussr01.dat-ussr25.dat; Files 16-40).

C FORTRAN program to read the USSR 6-and 3-hourly data files C

INTEGER WMO, YEAR, MONTH, DAY, HOUR, RH, RHQF, VAPORP, VAPQF,

* SLP, SLPQF, HDEF, HDEFQF, PCHR, PCHRQF, PTND,

* PTNDQF, VIS, VISCF, VISQF, HCLD, HCLDCF, HCLDQF, TDEW,

* TDEWQF, GRND, GRNDQF, TCLD, TCLDCF, TCLDQF, LCLD, LCLDCF,

* LCLDQF, WDIR, WDIRQF, WSPD, WSPDQF, PRCP, PRCPCF, PRCPQF,

* STAP, STAPQF, SOILT, SOILQF, W, WCF, WQF, WW, WWQF, AIRT,

* AIRTQF, APH1, APH1CF, APH1QF, APH2, APH2CF, APH2QF, APH3,

* APH3CF, APH3QF, APH4, APH4CF, APH4QF, APH5, APH5CF,

* APH5QF, APH6, APH6CF, APH6QF, APH7, APH7CF, APH7QF, CLDH,

* CLDHCF, CLDHQF, CLDM, CLDMQF, CLDL1, CLDL1F, CLDL2,

* CLDL2F, CLDL3, CLDL3F, WIR, WIRF

OPEN (UNIT=1, FILE='Ussr01.dat')

$10 \operatorname{READ}(1,100$, END=99) WMO, YEAR, MONTH, DAY, HOUR, RH, RHQF, VAPORP,

* VAPQF, SLP, SLPQF, HDEF, HDEFQF, PCHR, PCHRQF, PTND,

* PTNDQF, VIS, VISCF, VISQF, HCLD, HCLDCF, HCLDQF,

* TDEW, TDEWQF, GRND, GRNDQF, TCLD, TCLDCF, TCLDQF, LCLD,

* LCLDCF, LCLDQF, WDIR, WDIRQF, WSPD, WSPDQF, PRCP, PRCPCF,

* PRCPQF, STAP, STAPQF, SOILT, SOILQF, W, WCF, WQF, WW,

* WWQF, AIRT, AIRTQF, APH1, APH1CF, APH1QF, APH2, APH2CF,

* APH2QF, APH3, APH3CF, APH3QF, APH4, APH4CF, APH4QF, APH5,

* APH5CF, APH5QF, APH6, APH6CF, APH6QF, APH7, APH7CF,

* APH7QF, CLDH, CLDHCF, CLDHQF, CLDM, CLDMQF, CLDL1, CLDL1F, 
* CLDL2, CLDL2F, CLDL3, CLDL3F, WIR, WIRF

100 FORMAT (I5, I3, 3I2, 2 (I3,I1), I5, I1, I3, 3I1, I3, I1, I2,

* 2I1, I2, 2I1, I3, 3I1, 2(I2,2I1), 2(I2,I1), I4, 2I1, I5,

* I1, I3, 4I1, I2, I1, I4, 35I1)

99 STOP

END

INVENT.SAS (FILE 7)

This file contains the $\mathrm{SAS}^{-}$program to read station.inv (File 12). The following is a listing of the program.

* SAS program to read "station.inv" (File 12);

*;

DATA INVENT;

INFILE 'station.inv';

INPUT WMO 1-5 NAME \$ 7-31 LAT 33-37 LON 39-45 ELEV 47-52

RUN;

BMONTH 57-58 BYEAR 60-63 EMONTH 65-66 EYEAR 68-71;

\section{GAPS.SAS (FILE 8)}

This file contains the $S A S^{\circledR}$ program to read gaps.dat (File 13). The following is a listing of the program.

* SAS program to read "gaps.dat" (File 13);

*;

DATA GAPS;

INFILE 'gaps.dat';

INPUT WMO 1-5 GAP \$ 9-25;

RON;

\section{TIMEZONE.SAS (FILE 9)}

This file contains the SAS ${ }^{\otimes}$ program to read timezone.dat (File 14). The following is a listing of the program.

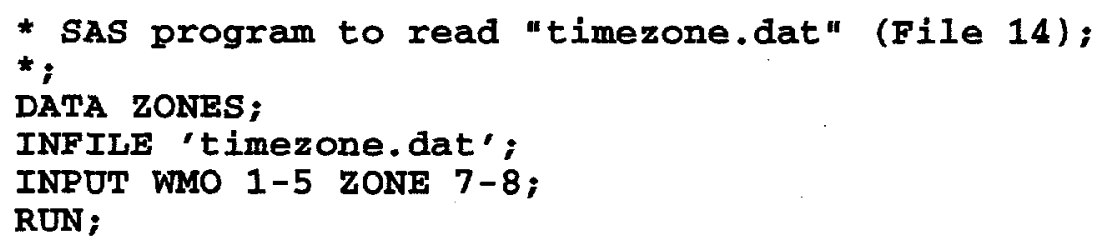

HISTORY.SAS (FILE 10)

This file contains the $\mathrm{SAS}^{\circledR}$ program to read station.his (File 15). The following is a 
listing of the program.

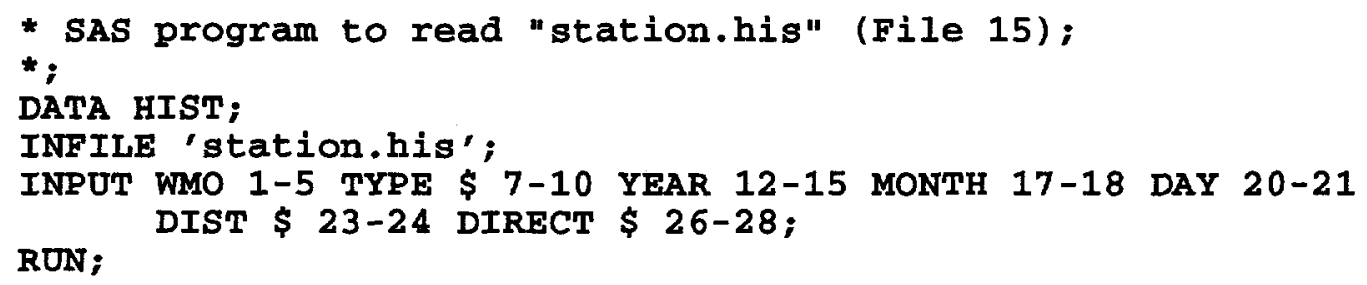

\section{DATA.SAS (FILE 11)}

This file contains a SAS ${ }^{\circledR}$ program (listed below) for reading any of the U.S.S.R. 6- and 3-hourly data files (ussr01.dat-ussr25.dat; Files 16-40).

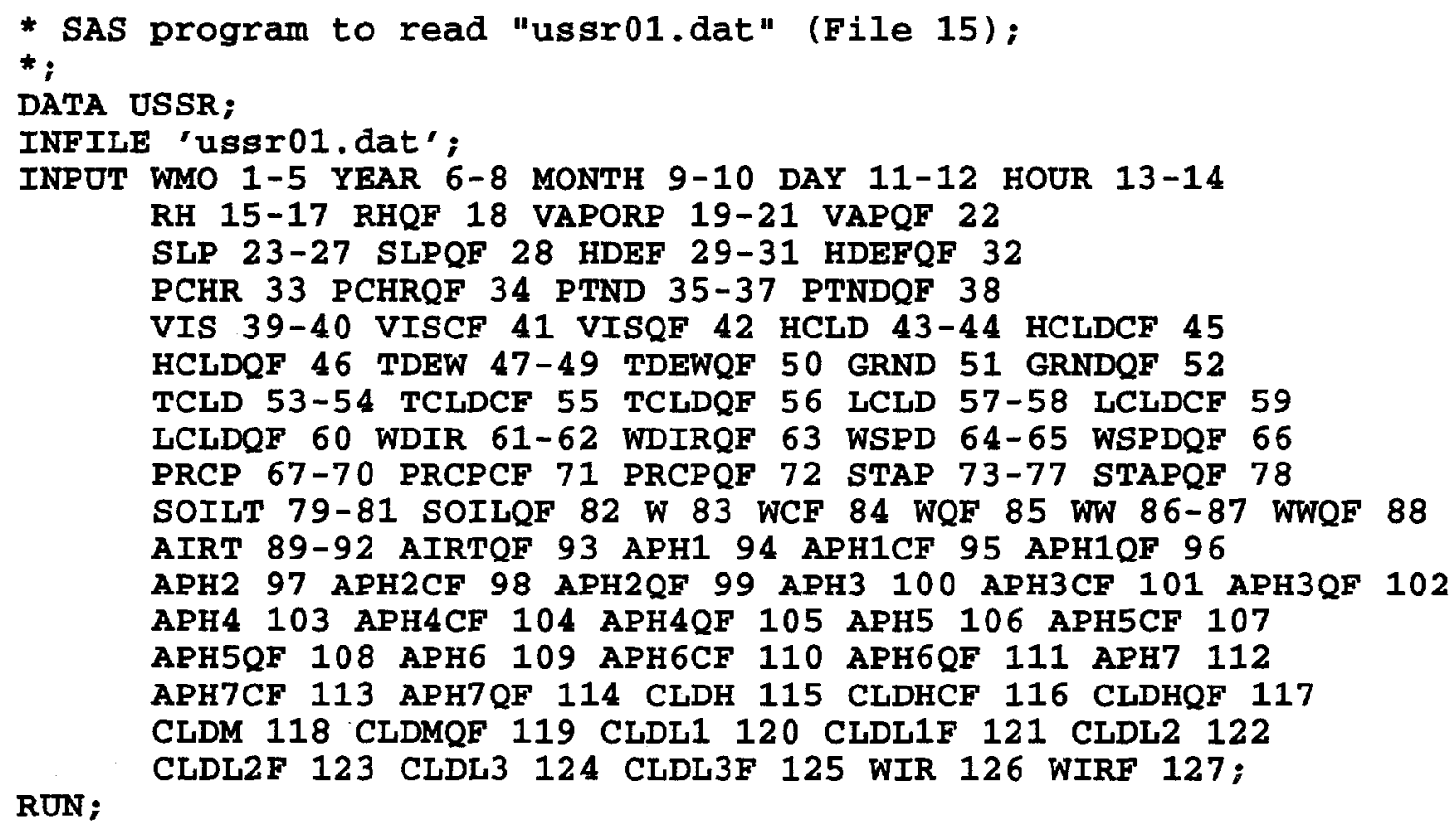

\section{STATION.INV (FILE 12)}

This file contains the WMO number, name, latitude, longitude, elevation, beginning month and year of record, and ending month and year of record for each of the 223 stations. Stated in tabular form, the contents include 


\begin{tabular}{llccc}
\hline Variable & $\begin{array}{c}\text { Variable } \\
\text { type }\end{array}$ & $\begin{array}{c}\text { Variable } \\
\text { width }\end{array}$ & $\begin{array}{c}\text { Starting } \\
\text { column }\end{array}$ & $\begin{array}{c}\text { Ending } \\
\text { column }\end{array}$ \\
\hline WMO & Numeric & 5 & 1 & 5 \\
NAME & Character & 25 & 7 & 31 \\
LAT & Numeric & 5 & 33 & 37 \\
LON & Numeric & 7 & 39 & 45 \\
ELEV & Numeric & 6 & 47 & 52 \\
BMONTH & Numeric & 2 & 57 & 58 \\
BYEAR & Numeric & 4 & 60 & 63 \\
EMONTH & Numeric & 2 & 65 & 66 \\
EYEAR & Numeric & 4 & 68 & 71 \\
& & & & \\
\hline
\end{tabular}

where

WMO is the WMO No. of the station;

NAME is the name of the station;

LAT is the latitude of the station in decimal degrees north;

LON is the longitude of the station in decimal degrees east;

ELEV is the elevation of the station above sea level (meters)-missing elevations are coded as -999.9;

BMONTH is the beginning month of the station's period of record;

BYEAR is the beginning year of the station's period of record;

EMONTH is the ending month of the station's period of record; and

EYEAR is the ending year of the station's period of record.

\section{GAPS.DAT (FILE 13)}

This file contains information on stations that have at least one gap at least one month in duration at any time during their period of record. There are only two variables in the file: WMO (WMO station number, a numeric variable in columns 1-5) and GAP (month/year with no data or the range of months/years with no data, a character variable in columns 9-25). 
TIMEZONE.DAT (FILE 14)

This file contains information for converting observations at each U.S.S.R. station from GMT to LMT. There are only two variables in the file: WMO (WMO station number, a numeric variable in columns 1-5) and ZONE (the number of hours that must be added to the GMT of an observation at that particular station to attain the LMT of the observation, a numeric variable in columns $7-8$ ranging from 3 to $13 \mathrm{~h}$ ).

\section{STATION.HIS (FILE 15)}

This file contains information on rain gauge replacement dates and information on the date, direction, and distance of any station relocations. There are two types of entries for each station. One type contains the station's WMO No. and rain gauge replacement date. The other type contains the station's WMO No. and a relocation date, distance, and direction. The file is sorted by WMO No., year, month, and day. Stated in tabular form, the contents include

\begin{tabular}{llccc}
\hline Variable & $\begin{array}{c}\text { Variable } \\
\text { type }\end{array}$ & $\begin{array}{c}\text { Variable } \\
\text { width }\end{array}$ & $\begin{array}{c}\text { Starting } \\
\text { column }\end{array}$ & $\begin{array}{c}\text { Ending } \\
\text { column }\end{array}$ \\
\hline WMO & Numeric & 5 & 1 & 5 \\
TYPE & Character & 4 & 7 & 10 \\
YEAR & Numeric & 4 & 12 & 15 \\
MONTH & Numeric & 2 & 17 & 18 \\
DAY & Numeric & 2 & 20 & 21 \\
DIST & Character & 2 & 26 & 28 \\
DIRECT & Character & 3 & & \\
\hline
\end{tabular}

where

WMO is the WMO No. of the station;

TYPE is the type of change indicated by this entry. The possible values of TYPE are as follows:

RAIN = rain gauge replacement (i.e., change from old-type gauge to Tretyakov-type gauge). Each station will have only one RAIN entry. When this type of entry is used, DIST and DIRECT (described below) are not relevant and thus are coded as blanks;

MOVE = station relocation. Each station will have at least one MOVE entry. If a station moved on more than one occasion, then separate entries are included for each 
relocation. If a station never moved, then that station will have only one MOVE entry; in this entry, YEAR, MONTH, DAY, DIST, and DIRECT (described below) are all coded as missing. In other words, if a station has only one MOVE entry, and if all variables in that MOVE entry are coded as missing, then the given station never moved;

YEAR is the year in which the change took place. Missing years are coded as -999 ;

MONTH is the month in which the change took place. Missing months are coded as -9 ;

DAY is the day on which the change took place. Missing days are coded as -9 ;

DIST is the distance $(\mathrm{km})$ that the station was moved. Missing distances are coded as -9 . A distance of zero indicates that the station moved less than $1 \mathrm{~km}$. DIST only applies to station relocation entries (i.e., lines in which TYPE $=$ MOVE). In rain gauge replacement entries (i.e., lines in which TYPE = RAIN), DIST is not relevant and thus is coded as blanks; and

DIRECT is the direction in which the station was moved (e.g., $\mathrm{N}=$ north, $\mathrm{SE}=$ southeast). Missing directions are coded as -99 . DIRECT only applies to station relocation entries (i.e., lines in which TYPE = MOVE). In rain gauge replacement entries (i.e., lines in which TYPE = RAIN), DIRECT is not relevant and thus is coded as blanks.

\section{USSR01.DAT-USSR25.DAT (Files 16-40)}

These files contain the 6- and 3-hourly meteorological observations from the 223 stations. The date and time in all data records correspond with GMT. Stated in tabular form, the contents include the following numeric variables

\begin{tabular}{lccc}
\hline Variable & $\begin{array}{c}\text { Variable } \\
\text { width }\end{array}$ & $\begin{array}{c}\text { Starting } \\
\text { column }\end{array}$ & $\begin{array}{c}\text { Ending } \\
\text { column }\end{array}$ \\
\hline WMO & 5 & 1 & 5 \\
YEAR & 3 & 6 & 8 \\
MONTH & 2 & 9 & 10 \\
DAY & 2 & 11 & 12 \\
HOUR & 2 & 13 & 14 \\
RH & 3 & 15 & 17
\end{tabular}




\begin{tabular}{|c|c|c|c|}
\hline Variable & $\begin{array}{l}\text { Variable } \\
\text { width }\end{array}$ & $\begin{array}{l}\text { Starting } \\
\text { column }\end{array}$ & $\begin{array}{l}\text { Ending } \\
\text { column }\end{array}$ \\
\hline RHQF & 1 & 18 & 18 \\
\hline VAPORP & 3 & 19 & 21 \\
\hline VAPQF & 1 & 22 & 22 \\
\hline SLP & 5 & 23 & 27 \\
\hline SLPQF & 1 & 28 & 28 \\
\hline HDEF & 3 & 29 & 31 \\
\hline HDEFQF & 1 & 32 & 32 \\
\hline PCHR & 1 & 33 & 33 \\
\hline PCHRQF & 1 & 34 & 34 \\
\hline PTND & 3 & 35 & 37 \\
\hline PTNDQF & 1 & 38 & 38 \\
\hline VIS & 2 & 39 & 40 \\
\hline VISCF & 1 & 41 & 41 \\
\hline VISQF & 1 & 42 & 42 \\
\hline HCLD & 2 & 43 & 44 \\
\hline HCLDCF & 1 & 45 & 45 \\
\hline HCLDQF & 1 & 46 & 46 \\
\hline TDEW & 3 & 47 & 49 \\
\hline TDEWQF & 1 & 50 & 50 \\
\hline GRND & 1 & 51 & 51 \\
\hline GRNDQF & 1 & 52 & 52 \\
\hline TCLD & 2 & 53 & 54 \\
\hline TCLDCF & 1 & 55 & 55 \\
\hline TCLDQF & 1 & 56 & 56 \\
\hline LCLD & 2 & 57 & 58 \\
\hline LCLDCF & 1 & 59 & 59 \\
\hline LCLDQF & 1 & 60 & 60 \\
\hline WDIR & 2 & 61 & 62 \\
\hline WDIRQF & 1 & 63 & 63 \\
\hline WSPD & 2 & 64 & 65 \\
\hline WSPDQF & 1 & 66 & 66 \\
\hline PRCP & 4 & 67 & 70 \\
\hline PRCPCF & 1 & 71 & 71 \\
\hline PRCPQF & 1 & 72 & 72 \\
\hline STAP & 5 & 73 & 77 \\
\hline STAPQF & 1 & 78 & 78 \\
\hline SOILT & 3 & 79 & 81 \\
\hline SOILQF & 1 & 82 & 82 \\
\hline W & 1 & 83 & 83 \\
\hline WCF & 1 & 84 & 84 \\
\hline WQF & 1 & 85 & 85 \\
\hline WW & 2 & 86 & 87 \\
\hline
\end{tabular}




\begin{tabular}{|c|c|c|c|}
\hline Variable & $\begin{array}{c}\text { Variable } \\
\text { width }\end{array}$ & $\begin{array}{l}\text { Starting } \\
\text { column }\end{array}$ & $\begin{array}{l}\text { Ending } \\
\text { column }\end{array}$ \\
\hline WWQF & 1 & 88 & 88 \\
\hline AIRT & 4 & 89 & 92 \\
\hline AIRTQF & 1 & 93 & 93 \\
\hline APH1 & 1 & 94 & 94 \\
\hline APH1CF & 1 & 95 & 95 \\
\hline APH1QF & 1 & 96 & 96 \\
\hline APH2 & 1 & 97 & 97 \\
\hline $\mathrm{APH} 2 \mathrm{CF}$ & 1 & 98 & 98 \\
\hline $\mathrm{APH} 2 \mathrm{QF}$ & 1 & 99 & 99 \\
\hline APH3 & 1 & 100 & 100 \\
\hline $\mathrm{APH} 3 \mathrm{CF}$ & 1 & 101 & 101 \\
\hline APH3QF & 1 & 102 & 102 \\
\hline APH4 & 1 & 103 & 103 \\
\hline $\mathrm{APH} 4 \mathrm{CF}$ & 1 & 104 & 104 \\
\hline APH4QF & 1 & 105 & 105 \\
\hline APH5 & 1 & 106 & 106 \\
\hline APH5CF & 1 & 107 & 107 \\
\hline APH5QF & 1 & 108 & 108 \\
\hline APH6 & 1 & 109 & 109 \\
\hline APH6CF & 1 & 110 & 110 \\
\hline APH6QF & 1 & 111 & 111 \\
\hline APH7 & 1 & 112 & 112 \\
\hline APH7CF & 1 & 113 & 113 \\
\hline APH7QF & 1 & 114 & 114 \\
\hline CLDH & 1 & 115 & 115 \\
\hline CLDHCF & 1 & 116 & 116 \\
\hline CLDHQF & 1 & 117 & 117 \\
\hline CLDM & 1 & 118 & 118 \\
\hline CLDMQF & 1 & 119 & 119 \\
\hline CLDL1 & 1 & 120 & 120 \\
\hline CLDL1F & 1 & 121 & 121 \\
\hline CLDL2 & 1 & 122 & 122 \\
\hline CLDL2F & 1 & 123 & 123 \\
\hline CLDL3 & 1 & 124 & 124 \\
\hline CLDL3F & 1 & 125 & 125 \\
\hline WIR & 1 & 126 & 126 \\
\hline WIRF & 1 & 127 & 127 \\
\hline
\end{tabular}

where 
WMO is the WMO number of the station;

YEAR is the year (Greenwich) of the observations in the record;

MONTH is the month (Greenwich) of the observations in the record;

DAY is the day (Greenwich) of the observations in the record;

HOUR is the GMT of the observations in the record;

RH is the relative humidity of the air (expressed in percent) as determined by use of a psychrometer. Relative humidity is defined as the ratio of the observed vapor pressure to the saturation vapor pressure for the observed air temperature. Values of observations may range from 0 to $100 \%$. Missing observations are coded as 999;

RHQF is the quality flag for the relative humidity observation ( 0 indicates a valid observation; 9 indicates a suspect or missing observation);

VAPORP is the water vapor pressure of the air [expressed in tenths of hectopascals $(\mathrm{hPa})$ ] as determined by use of a psychrometer. The water vapor pressure is the partial pressure of the water vapor contained in the air. Values of observations considered valid may range from 0.0 to $95.0 \mathrm{hPa}$. Missing observations are coded as 999 ;

VAPQF is the quality flag for the water vapor pressure observation ( 0 indicates a valid observation; 9 indicates a suspect or missing observation);

SLP is the sea level pressure of the air (expressed in tenths of $\mathrm{hPa}$ ) as determined by use of a barometer. Because a station would rarely be able to position a barometer precisely at sea level, the air pressure measured at a station is "reduced" to sea level by using a standard barometric height formula. Values of observations considered valid may range from 900.0 to $1100.0 \mathrm{hPa}$. At stations located above a certain elevation $(500 \mathrm{~m}$ through $1980 ; 800 \mathrm{~m}$ since 1981), air pressure is not reduced to sea level, but is assigned the missing code 99999 ;

SLPQF is the quality flag for the sea level pressure observation ( 0 indicates a valid observation; 9 indicates a suspect or missing observation);

HDEF is the humidity deficit (saturation deficiency); the difference between the saturation vapor pressure and the actual water vapor pressure at a given temperature and pressure as measured in tenths of $\mathrm{hPa}$. Valid values may range from 0.0 to $95.0 \mathrm{hPa}$. Missing observations are coded as 999 ;

HDEFQF is the quality flag for the humidity deficit observation ( 0 indicates a valid observation; 9 indicates a suspect or missing observation); 
PCHR is the pressure tendency characteristic, corresponding to the shape of the barograph trace of air pressure at the station for the preceding 3-h period. This is a coded value ranging from 0 to 8 , as explained below (a missing value is coded as 9):

0 = increasing, then decreasing; pressure unchanged or higher than $3 \mathrm{~h}$ ago;

1 = increasing, then steady; increasing, then weaker increase; current pressure is higher than $3 \mathrm{~h}$ ago;

$2=$ uniform or non-uniform increase; current pressure is higher than $3 \mathrm{~h}$ ago;

3 = decreasing, then increasing; steady, then increasing; or increasing, then increasing more rapidly; current pressure is higher than $3 \mathrm{~h}$ ago;

$4=$ steady; pressure is the same as $3 \mathrm{~h}$ ago;

$5=$ decreasing, then increasing; pressure is the same or lower than $3 \mathrm{~h}$ ago;

$6=$ decreasing, then steady; or decreasing then decreasing more slowly; current pressure is lower than $3 \mathrm{~h}$ ago;

7 = decreasing steadily or unsteadily; current pressure is lower than $3 \mathrm{~h}$ ago;

8 = increasing, then decreasing; steady, then decreasing; or decreasing, then decreasing more quickly; current pressure is lower than $3 \mathrm{~h}$ ago;

PCHRQF is the quality flag for the pressure tendency characteristic ( 0 indicates a valid observation; 9 indicates a suspect or missing observation);

PTND is the pressure tendency value (i.e., the absolute difference between the current air pressure at the station and that which was observed $3 \mathrm{~h}$ before). The sign of PTND is indicated by the value of PCHR: if PCHR is equal to $0,1,2$, or 3, then PTND is positive; if PCHR is equal to 4 then PTND should equal 0 ; and, if PCHR is equal to $5,6,7$, or 8 , then PTND is negative. Values are given in tenths of $\mathrm{hPa}$; observations considered valid may range from 0.0 to $20.0 \mathrm{hPa}$, and a missing observation is coded as 999);

PTNDQF is the quality flag for the pressure tendency value ( 0 indicates a valid observation; 9 indicates a suspect or missing observation);

VIS is the horizontal visibility, given as a coded value indicating distance in $\mathrm{km}$. The horizontal visibility is defined as the maximum distance at which an absolutely black body of rather large angular dimensions (over 15 angular $\mathrm{min}$ ) can be distinguished against the background of the sky in daylight, or the distance at which an unfocused light source of a given intensity becomes indistinguishable at night. Horizontal visibility depends on atmospheric phenomena. Thus, in the fog it can be reduced to zero, while in clear arctic air it can reach hundreds of kilometers. Coded values 
may range from 00 to 50 and from 56 to 99 . Codes $00-50$ and $56-89$ are used when visibility is measured using instruments; codes 90-99 are used when visibility is estimated visually. The codes and their meanings are as follows:

$$
\begin{aligned}
& 00-50=\text { indicates visibility in tenths of } \mathrm{km} \text { (i.e., } 0.0 \mathrm{~km} \text { to } 5.0 \mathrm{~km} \text { ). } \\
& \text { For example, } 25=2.5 \mathrm{~km} \text { ( } 00 \text { is the code for visibility less } \\
& \text { than } 0.1 \mathrm{~km} \text { ); } \\
& \text { 51-55 = not used; } \\
& 56-80=\text { the range } 6 \mathrm{~km} \text { to } 30 \mathrm{~km} \text {. Visibility in whole kilometers } \\
& \text { may be determined by subtracting } 50 \text { from the code, e.g., a } \\
& \text { code of } 65 \text { indicates the visibility is } 15 \mathrm{~km} \text {; } \\
& 81=35 \mathrm{~km} \text {; } \\
& 82=40 \mathrm{~km} \text {; } \\
& 83=45 \mathrm{~km} \text {; } \\
& 84=50 \mathrm{~km} \text {; } \\
& 85=55 \mathrm{~km} \text {; } \\
& 86=60 \mathrm{~km} \text {; } \\
& 87=65 \mathrm{~km} \text {; } \\
& 88=70 \mathrm{~km} \text {; } \\
& 89=>70 \mathrm{~km} \\
& 90=<0.05 \mathrm{~km} \text {; } \\
& 91=0.05 \mathrm{~km} \text {; } \\
& 92=0.2 \mathrm{~km} \text {; } \\
& 93=0.5 \mathrm{~km} \text {; } \\
& 94=1 \mathrm{~km} \text { (about } 1 / 2 \text { mile); } \\
& 95=2 \mathrm{~km} \text { (about } 1 \text { mile); } \\
& 96=4 \mathrm{~km} \text { (about } 2 \text { miles); } \\
& 97=10 \mathrm{~km} \text { (about } 6 \text { miles); } \\
& 98=20 \mathrm{~km} \text { (about } 12 \text { miles); and } \\
& 99=>50 \mathrm{~km} \text { (>30 miles). }
\end{aligned}
$$

If VIS $=99$ with both the complement and quality flags set to 9 (see below), the observation is missing.

VISCF is the horizontal visibility complement flag. VISCF $=0$ indicates the visibility corresponds to the value given for VIS; VISCF $=1$ indicates the visibility is actually greater than the value given for VIS; VISCF $=9$ indicates a suspect or missing observation;

VISQF is the quality flag for the horizontal visibility value ( 0 indicates a valid observation; 9 indicates a suspect or missing observation);

HCLD is the height above ground of the base of the lowest cloud. This height is usually coded in hundreds of meters, as detailed in the following:

$$
\begin{array}{ll}
00 & =\leq 50 \mathrm{~m} \text { with fog present; } \\
01-25 & =100 \mathrm{~m} \text { to } 2500 \mathrm{~m}, \text { e.g., } 10=1000 \mathrm{~m}
\end{array}
$$


$98=$ no clouds below $2500 \mathrm{~m}$, however there may be mid- or high-level clouds whose height has not been determined;

$99=$ no clouds or traces of clouds whose height has not been determined; or observation is missing if both complement and quality flags are set to 9 (see below);

HCLDCF is the complement flag for the lowest cloud height observation. A value of 0 means the height was measured using instrumentation; a value of 1 indicates the height was estimated visually. This flag is set to 9 in the case of a suspect or missing observation;

HCLDQF is the quality flag for the lowest cloud height observation ( 0 indicates a valid observation; 9 indicates a suspect or missing observation);

TDEW is the dew point temperature in whole degrees celsius. The dew point temperature is defined as the temperature to which moist air must be cooled, with air pressure and water vapor pressure held constant, in order that it just reach saturation with respect to the water in the air. The dew point is determined by using a psychrometer. Observations considered valid may range from $-70^{\circ}$ to $+40^{\circ} \mathrm{C}$. Missing observations are coded as 999;

TDEWQF is the quality flag for the dew point temperature $(0$ indicates a valid observation; 9 indicates a suspect or missing observation);

GRND is the ground state, a visual observation of the state of the ground surface in the vicinity of the station made usually near 0800 and 2000 LMT. This is a coded value as detailed in the following:

$0=$ surface of ground dry (no appreciable amount of dust or loose sand);

$1=$ surface of ground moist (no pools);

$2=$ surface of ground wet (standing water in small or large pools on surface);

3 = surface of ground frozen;

$4=$ glaze on ground, but no snow or melting snow;

5 = ice, snow, or melting snow covering less than one-half of the ground;

$6=$ ice, snow, or melting snow covering more than one-half of the ground;

7 = ice, snow, or melting snow covering ground completely;

$8=$ loose dry snow, dust, or sand covering more than one-half of the ground;

$9=$ loose dry snow, dust, or sand covering ground completely (if GRNDQF = 0; otherwise, the observation is missing);

GRNDQF is the quality flag for the ground state observation ( 0 indicates a valid observation; 9 indicates a suspect or missing observation); 
TCLD is the total cloud amount, estimated visually by an observer according to a 10-point system (i.e., in tenths of sky cover). A value of 0 indicates no clouds present or $<1 / 10$ sky cover, a value of 10 indicates an overcast sky (with or without gaps amounting to $<1 / 10$ sky cover; see explanation of complement flag below), and a value of 99 indicates a missing observation. The gaps between individual cloud elements, typical of some cloud genera (e.g., altocumulus and stratocumulus) are not to be included as part of the total cloud cover estimate (i.e., they are counted as clear sky);

TCLDCF is the total cloud amount complement flag. TCLDCF $=1$ is used if 10-point cloudiness (overcast) is observed with gaps; TCLDCF $=0$ is coded for all other valid cloud amounts; and TCLDCF $=9$ indicates a suspect or missing observation;

TCLDQF is the quality flag for the total cloud amount observation ( 0 indicates a valid observation; 9 indicates a suspect or missing observation);

LCLD is the low-cloud amount, estimated visually by an observer according to a 10-point system (i.e., in tenths of sky cover). A value of 0 indicates no low clouds present or $<1 / 10$ of the sky is covered with low clouds. The gaps between individual cloud elements, typical of some cloud genera (e.g., stratocumulus and cumulus) are not to be included as part of the low cloud cover estimate (i.e., they are counted as clear sky). Missing observations are coded as 99 ;

LCLDCF is the low-cloud amount complement flag. TCLDCF $=1$ is used if 10-point cloudiness (overcast) is observed with gaps; TCLDCF $=0$ is coded for all other valid low-cloud amounts; and TCLDCF $=9$ indicates a suspect or missing observation;

LCLDQF is the quality flag for the total cloud amount observation (0 indicates a valid observation; 9 indicates a suspect or missing observation);

WDIR is the direction from which the wind is blowing, as measured 10-12 $\mathrm{m}$ above ground level. This is a coded observation, the values for which are given as follows:

\begin{tabular}{|c|c|c|}
\hline \multicolumn{2}{|l|}{ Code } & Wind direction \\
\hline 00 & $=$ & calm winds \\
\hline 02 & $=$ & NNE \\
\hline 05 & $=$ & NE \\
\hline 07 & $=$ & ENE \\
\hline 09 & $=$ & E \\
\hline 11 & $=$ & ESE \\
\hline 14 & $=$ & SE \\
\hline 16 & $=$ & SSE \\
\hline 18 & $=$ & $S$ \\
\hline
\end{tabular}




$\begin{array}{lll}20 & = & \mathrm{SSW} \\ 23 & = & \mathrm{SW} \\ 25 & = & \mathrm{WSW} \\ 27 & = & \mathrm{W} \\ 29 & = & \mathrm{WNW} \\ 32 & = & \mathrm{NW} \\ 34 & = & \mathrm{NNW} \\ 36 & = & \mathrm{N} \\ 99 & = & \text { variable winds (if WDIRQF }=0 \text {; otherwise, the } \\ & & \text { observation is missing); }\end{array}$

WDIRQF is the quality flag for the wind direction observation ( 0 indicates a valid observation; 9 indicates a suspect or missing observation). Missing observations are coded as 99 ;

WSPD is the wind speed in $\mathrm{m} / \mathrm{s}$ as measured $10-12 \mathrm{~m}$ above ground level. Observations considered valid may range from 0 to $60 \mathrm{~m} / \mathrm{s}$;

WSPDQF is the quality flag for the wind speed observation ( 0 indicates a valid observation; 9 indicates a suspect or missing observation);

PRCP is the precipitation amount to the nearest tenth of a millimeter. Observations considered valid may range from 0 to $5000(0 \mathrm{~mm}$ to 500 $\mathrm{mm}$ ). Missing observations are coded as 999 . Rain gauges are positioned $2 \mathrm{~m}$ above ground level, and were read at 0700 and $1900 \mathrm{LMT}$ from 1936 through 1965. In 1946, the old-style gauge (exact type unknown) was replaced with the Tretyakov-type gauge (see Appendix A for the date of implementation at each site). Beginning in 1966, gauges were read at $0300,0900,1500$, and 2100 MLT in time zone 2; at 0300, 0600, 1500, and 1800 MLT in zones 3-5; at 0300 and 1500 MLT in zones 6-8; at $0000,0300,1200$, and 1500 MLT in zones 9-11; and at 2100, 0300, 0900, and 1500 MLT in zone 12. Also, beginning in 1966, wetting corrections of $\leq 0.2 \mathrm{~mm}$ were applied to each hourly measurement. (Because four observations per day were collected at stations in time zones 2-5 and 9-12, four corrections were counted in the calculation of daily totals; therefore, total daily corrections are higher for stations in these areas.) From 1966 onward, readings at some stations were also taken at the observing hours closest to 0800 and 2000 LMT. Beginning in 1986, readings at 0300 and $1500 \mathrm{MLT}$ were discontinued at all stations except those in time zone 2. (The term "time zone" in the preceding corresponds to assigning the numbers $1-12$ to 12 time zones stretching from west to east across the former U.S.S.R. The time zone of each station in this sense may be obtained by subtracting 1 from the value of the ZONE variable in the file TIMEZONE.DAT.)

PRCPCF is the precipitation amount complement flag. It is set to 1 if a trace of precipitation has been measured, i.e., $<0.1 \mathrm{~mm}$. This flag is set to 0 for all other valid precipitation observations, and is set to 9 for suspect or missing 
precipitation observations;

PRCPQF is the quality flag for the precipitation amount ( 0 indicates a valid observation; 9 indicates a suspect or missing observation);

STAP is the pressure of the air at station level (expressed in tenths of $\mathrm{hPa}$ ) as determined by use of a barometer. Values of observations considered valid may range from 600.0 to $1100.0 \mathrm{hPa}$. Validity is of course assessed by considering the station's elevation above sea level. Missing observations are coded as 99999;

SLPQF is the quality flag for the station level pressure observation ( 0 indicates a valid observation; 9 indicates a suspect or missing observation);

SOILT is the soil surface temperature, expressed in whole degrees celsius. Soil surface temperature is measured at a smooth, unshaded site that is devoid of vegetation. When the ground is snow-covered, the thermometer is placed on the snow surface and the temperature of the snow cover is measured. Observations considered valid may range from -75 to $+75^{\circ} \mathrm{C}$. Missing observations are coded as 999;

SOILQF is the quality flag for the soil surface temperature ( 0 indicates a valid observation; 9 indicates a suspect or missing observation);

W

is the past weather code, used in describing the meteorological conditions observed between the past and current observations. At 0000, 0600, 1200, and 1800 GMT this code describes weather from the previous 6-hour period; at $0300,0900,1500$, and $2100 \mathrm{GMT}$ it describes weather for the previous 3-hour period. The codes and their meanings are as follows:

$0=$ clear sky or no more than $5 / 10$ s cloud amount;

1 = variable sky; cloud amount was both less than and greater than $5 / 10$ sky cover during the preceding three hours;

$2=$ overcast or cloud amount greater than 5/10s;

3 = sand or dust storm, or drifting or blowing snow;

$4=$ fog, ice fog, or thick haze or smoke;

$5=$ drizzle;

$6=$ rain;

$7=$ snow, or rain and snow mixed;

$8=$ shower(s);

$9=$ thunderstorm, with or without precipitation (if $\mathrm{WQF}=0$; otherwise, the observation is missing);

WCF is the past weather complement flag. It is set to 0 when used with the previously defined past weather codes, however it is set to 1 for past weather codes 3,7 , and 8 if the past weather also included a snowstorm. The complement flag is set to 9 in the case of a suspect or missing past weather observation; 
is the quality flag for the past weather observation ( 0 indicates a valid observation; 9 indicates a suspect or missing observation);

WW

is the present weather code, reflecting the meteorological conditions at the time of observation or during the preceding 1-h period. Codes range from 00 to 99 and are defined as follows:

\section{Code $\quad$ Present weather}

00-19 = no precipitation, fog, dust storm, sandstorm, drifting or blowing snow at the station at the time of observation and, except for codes 09 and 17, during preceding hour;

$00=$ cloud development conditions unknown;

$01=$ cloud generally dispersing;

02 = state of sky on the whole unchanged;

03 = clouds generally forming or developing;

$04=$ visibility reduced by smoke or volcanic ash;

$05=$ haze;

$06=$ widespread dust in suspension in the air;

$07=$ dust or sand raised by wind at or near the station at the time of observation;

$08=\quad$ well developed dust whirl(s) seen at or near the station;

$09=$ dust storm within sight;

$10=$ mist, steam mist (light fog);

11 = patches of shallow fog, or, from 1966 onward, ice fog;

$12=$ more or less continuous shallow fog, or, from 1966 onward, ice fog;

13 = lightning visible, no thunder heard;

$14=$ precipitation within sight, not reaching the ground;

$15=$ precipitation within sight, reaching the ground or the surface of the sea, but distant (i.e., estimated to be more than $5 \mathrm{~km}$ from the station);

$16=$ precipitation within sight, reaching the ground or the surface of the sea, near to, but not at the station;

$17=$ thunderstorm, but no precipitation at the station or within sight;

$18=$ squall;

19 = funnel cloud;

$20-29=$ precipitation, fog, ice fog, or thunderstorm at the station during the preceding hour but not at the time of the observation;

$20=$ drizzle or snow grains;

$21=$ rain;

22 = snow; 


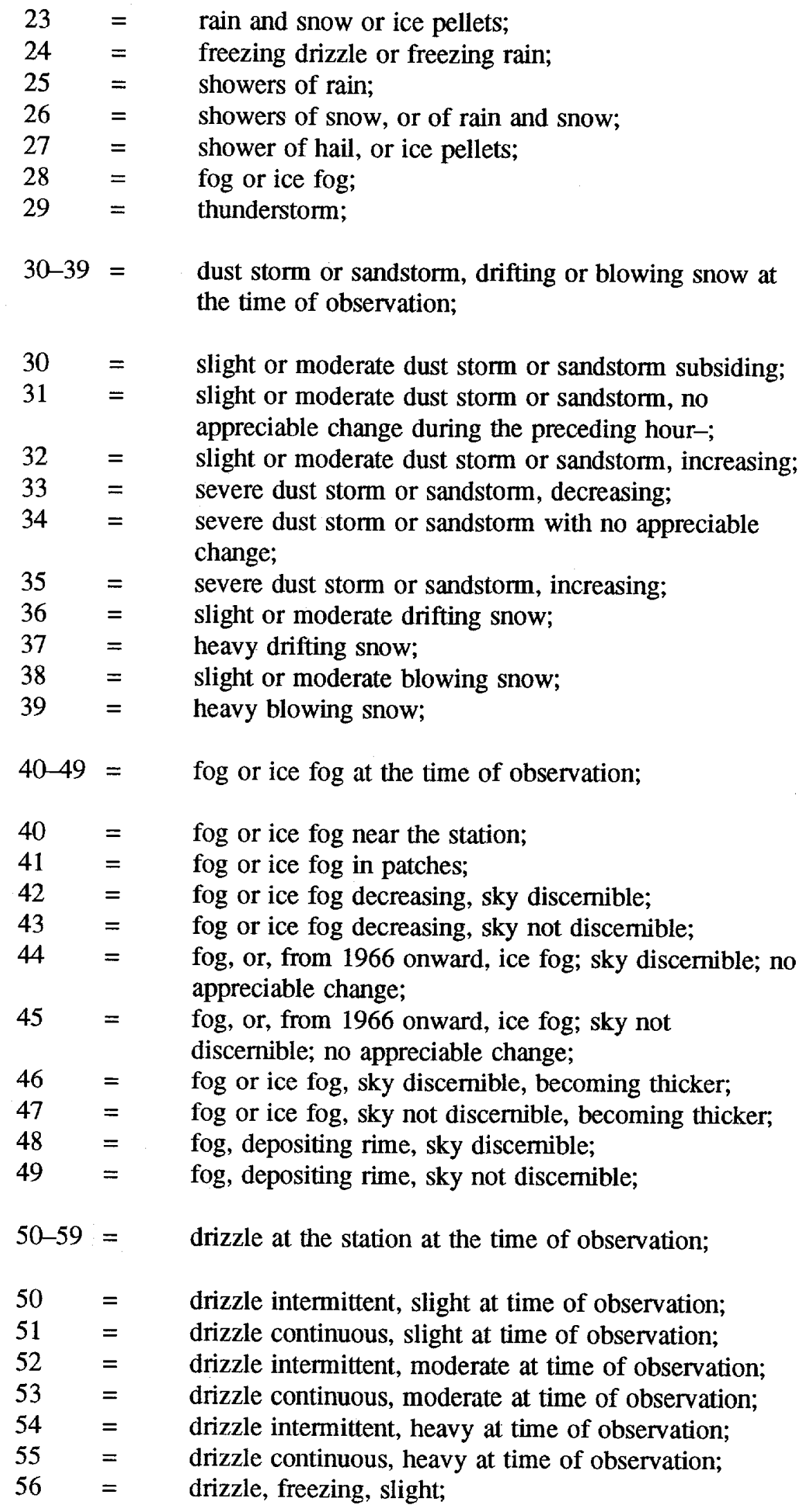




\begin{tabular}{|c|c|c|}
\hline 57 & $=$ & drizzle, freezing, heavy; \\
\hline 58 & $=$ & drizzle and rain, moderate or heavy; \\
\hline 59 & $=$ & drizzle and rain, moderate or heavy; \\
\hline $60-69$ & $=$ & rain at the station at the time of observation; \\
\hline 60 & $=$ & rain intermittent, slight; \\
\hline 61 & $=$ & rain continuous, slight; \\
\hline 62 & $=$ & rain intermittent, moderate; \\
\hline 63 & $=$ & rain continuous, moderate; \\
\hline 64 & $=$ & rain intermittent, heavy; \\
\hline 65 & $=$ & rain continuous, heavy; \\
\hline 66 & $=$ & rain, freezing, slight; \\
\hline 67 & $=$ & rain, freezing, moderate or heavy; \\
\hline 68 & $=$ & rain or drizzle and snow, slight; \\
\hline 69 & $=$ & rain or drizzle and snow, moderate or heavy; \\
\hline $70-79$ & $=$ & $\begin{array}{l}\text { solid precipitation not in showers at the time of } \\
\text { observation; }\end{array}$ \\
\hline 70 & $=$ & intermittent fall of snow flakes, slight; \\
\hline 71 & $=$ & continuous fall of snow flakes, slight; \\
\hline 72 & $=$ & intermittent fall of snow flakes, moderate; \\
\hline 73 & $=$ & continuous fall of snow flakes, moderate; \\
\hline 74 & $=$ & intermittent fall of snow flakes, heavy; \\
\hline 75 & $=$ & continuous fall of snow flakes, heavy; \\
\hline 76 & $=$ & diamond dust; \\
\hline 77 & $=$ & snow grains; \\
\hline 78 & $=$ & isolated starlike snow crystals; \\
\hline 79 & $=$ & ice pellets; \\
\hline $80-90$ & $=$ & showery precipitation at the time of observation; \\
\hline 80 & $=$ & rain shower(s), slight; \\
\hline 81 & $=$ & rain shower(s), moderate or heavy; \\
\hline 82 & $=$ & rain shower(s), violent; \\
\hline 83 & $=$ & shower(s) of rain and snow mixed, slight; \\
\hline 84 & $=$ & shower(s) of rain and snow mixed, moderate or heavy; \\
\hline 85 & $=$ & snow shower(s), slight; \\
\hline 86 & $=$ & snow shower(s), moderate or heavy; \\
\hline 87 & $=$ & shower(s) of snow pellets or small hail, slight; \\
\hline 88 & $=$ & $\begin{array}{l}\text { shower(s) of snow pellets or small hail, moderate or } \\
\text { heavy; }\end{array}$ \\
\hline 89 & $=$ & shower(s) of hail, slight; \\
\hline 90 & $=$ & shower(s) of hail, moderate or heavy; \\
\hline $91-99$ & $=$ & $\begin{array}{l}\text { thunderstorm during the preceding hour or at the time } \\
\text { of observation; }\end{array}$ \\
\hline
\end{tabular}




$91=\quad \begin{aligned} & \text { slight rain at time of observation, thunderstorm during } \\ & \text { the preceding hour; } \\ & \text { moderate or heavy rain at time of observation, } \\ & \text { thunderstorm during the preceding hour; }\end{aligned}$
$93 \quad=\quad \begin{aligned} & \text { slight snow or hail at the time of observation, } \\ & \text { thunderstorm during the preceding hour; }\end{aligned}$
$94=\begin{aligned} & \text { moderate or heavy snow or hail at the time of } \\ & \text { observation, thunderstorm during preceding hour; } \\ & \text { thunderstorm, slight or moderate with rain and/or snow }\end{aligned}$
$95=\begin{aligned} & \text { at the time of observation; } \\ & \text { thunderstorm, slight or moderate with hail at the time } \\ & \text { of observation; } \\ & \text { thunderstorm, heavy, with rain or snow at time of } \\ & \text { observation; } \\ & \text { thunderstorm, combined with dust storm or sandstorm }\end{aligned}$
$97=\begin{aligned} & \text { at time of observation; } \\ & \text { thunderstorm, heavy, with hail at the time of } \\ & \text { observation (if WwQF }=0 \text {; otherwise, the observation } \\ & \text { is missing); }\end{aligned}$

WWQF is the quality flag for the present weather observation $(0$ indicates a valid observation; 9 indicates a suspect or missing observation);

AIRT is the air temperature (tenths of degrees celsius), measured $2 \mathrm{~m}$ above ground or snow surface level. Observations considered valid may range from $-70.0^{\circ}$ to $+55.0^{\circ} \mathrm{C}$. Missing observations are coded as 9999 ;

AIRTQF is the quality flag for air temperature ( 0 indicates a valid observation; 9 indicates a suspect or missing observation);

APH1-APH7 are seven atmospheric phenomena groups, used for reporting various atmospheric phenomena during the ten minutes preceding the observation hour. These phenomena are observed visually, as are estimates of their intensity. Atmospheric phenomena intensity can be weak, moderate or strong. The phenomena are described by means of codes that are particular to each of the seven groups. A coded value of 0 indicates that atmospheric phenomena were not observed at the time of observation. Additional codes and their meanings are as follows:

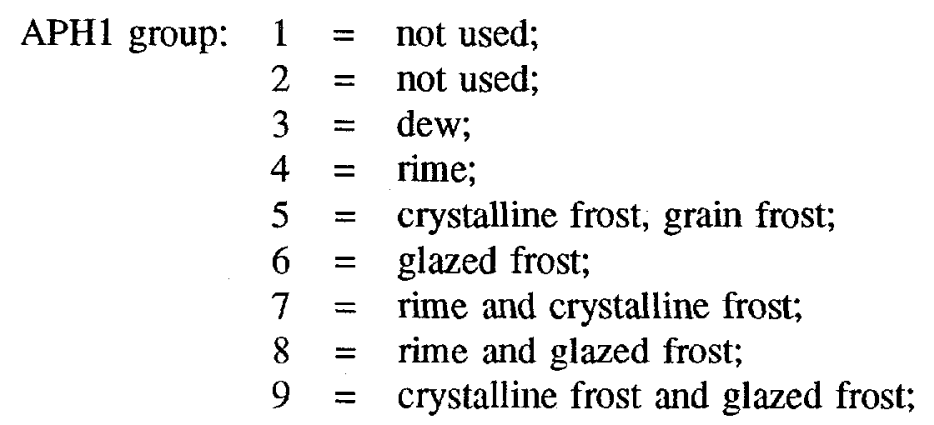


APH2 group: 1 = not used before 1966, from 1966 onward: snow haze;

2 = haze;

3 = mist;

4 = ground fog;

$5=$ crystalline fog, sky visible;

$6=$ ice fog;

7 = fog, sky visible;

8 = fog;

$9=$ not used before 1966, from 1966 onward: shallow ice fog;

APH3 group: $1=$ drifting dust;

2 = funnel cloud;

3 = dust storm;

4 = whirl;

5 = drifting snow;

6 = blowing snow;

7 = blizzard;

8 = snow storm;

9 = not used;

APH4 group: 1 = before 1966: corona around sun/moon; not used from 1966 onward;

2 = sunshine;

3 = before 1966: halo around sun/moon; not used from 1966 onward;

$4=$ snow grains and sunshine;

$5=$ snow pellets and sunshine;

$6=$ snow grains;

7 = snow pellets;

$8=$ ice pellets;

$9=$ ice pellets and sunshine;

APH5 group: 1 = not used;

2 = glazed rain;

3 = drizzle;

4 = rain;

$5=$ rain shower,

$6=$ glazed rain, rain;

$7=$ glazed rain, rain shower;

8 = not used;

9 = not used;

APH6 group: 1 = not used;

2 = mirage;

3 = ice needles;

4 = snow melting; 


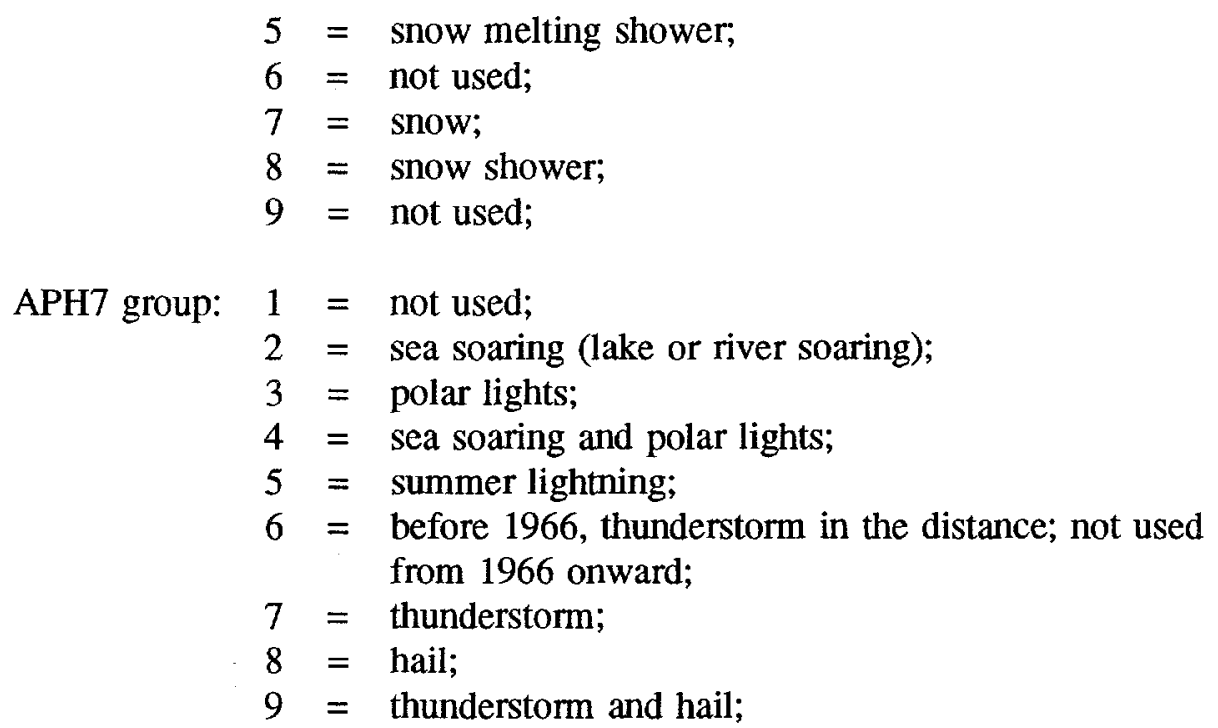

APH1CFAPH7CF

APH1QFAPH7QF

CLDH are the corresponding complement flags for the seven atmospheric phenomena groups. These flags are used to denote whether or not an observation has been made, and if so, to denote the intensity of the phenomena. A complement flag of 0 accompanying an atmospheric phenomena code of 0 means none of the phenomena in a particular group have been observed. When accompanying a nonzero phenomena code, a complement flag of 0 denotes phenomena of weak intensity, 1 denotes moderate intensity, and 2 denotes strong intensity. A complement flag of 9 , when accompanied by a quality flag of 9 (see below) indicates a suspect or missing observation;

are quality flags for the seven atmospheric phenomena groups ( 0 indicates a valid observation; 9 indicates a suspect or missing observation);

is the coded value for the high-level cloud type. High clouds are defined as those with bases higher than $6000 \mathrm{~m}$ and include cirrus (Ci), cirrocumulus $(\mathrm{Cc})$, and cirrostratus $(\mathrm{Cs})$ clouds. Codes have the following meanings:

$0=$ cloud type is not indicated, but low- or mid-level clouds observed, with total cloud amount ranging anywhere from $1 / 10$ to overcast with gaps; high-level clouds are absent or amount to less than $1 / 10$ sky cover;

$1=\mathrm{Ci}$;

$2=\mathrm{Cc}$

$3=\mathrm{Cs}$

$4=\mathrm{Ci}$ and $\mathrm{Cc}$;

$5=\mathrm{Ci}$ and $\mathrm{Cs}$;

$6=\mathrm{Cc}$ and $\mathrm{Cs}$;

$7=\mathrm{Ci}, \mathrm{Cc}$, and $\mathrm{Cs}$;

$8=$ high cloud presence and type cannot be determined because of 
continuous fog or snowstorm; or high-level cloud presence and type cannot be determined because of overcast conditions at lower levels;

$9=$ complete absence of clouds or, in the case of translucent fog, clear in the zenith (if CLDHQF $=0$; otherwise the observation is missing);

CLDHCF is the high-level cloud type complement flag. It is set to 0 when the high-level cloud type has been determined with no fog present; set to 1 when the high-level cloud type has been determined with translucent fog or when the high-level cloud type cannot be determined because of continuous fog; and set to 9 if the high-level cloud type is suspect or missing.

CLDHQF is the high-level cloud type quality flag ( 0 indicates a valid observation; 9 indicates a suspect or missing observation);

CLDM is the coded value for the mid-level cloud type. Mid-level clouds are defined as those with bases between $2000 \mathrm{~m}$ and $6000 \mathrm{~m}$; they include altocumulus (Ac) and altostratus (As) clouds. Codes have the following meanings:

$$
\begin{aligned}
0= & \text { cloud type is not indicated, but high-level clouds (amount } \\
& \text { ranging from } 1 / 10 \text { to overcast) and/or low-level clouds (amount } \\
& \text { ranging from } 1 / 10 \text { to overcast with gaps) observed; mid-level } \\
& \text { clouds are absent or amount to less than } 1 / 10 \text { sky cover; } \\
1= & \text { Ac; } \\
2= & \text { As; } \\
3= & \text { not used; } \\
4= & \text { Ac and As; } \\
5-7= & \text { not used; } \\
8= & \text { mid-level cloud presence and type cannot be determined due to } \\
& \text { fog or snowstorm; or mid-level cloud presence and type cannot } \\
& \text { be determined because of overcast at lower levels; } \\
9= & \text { complete absence of clouds or, in the case of translucent fog, } \\
& \text { clear in the zenith (if CLDMQF =0; otherwise the observation } \\
& \text { is missing); }
\end{aligned}
$$

CLDMQF is the mid-level cloud type quality flag ( 0 indicates a valid observation; 9 indicates a suspect or missing observation);

CLDL1 is the first of three code groups for describing low-level cloud type. Low-level clouds are defined as those with bases lower than $2000 \mathrm{~m}$; they include stratocumulus $(\mathrm{Sc})$, stratus $(\mathrm{St})$, nimbostratus $(\mathrm{Ns})$, cumulus $(\mathrm{Cu})$, and cumulonimbus $(\mathrm{Cb})$ clouds. Codes have the following meanings:

$0=$ cloud type is not indicated, but high- or mid-level clouds observed, with total cloud amount ranging anywhere from $1 / 10$ 
to overcast; low-level clouds of the CLDL1 group (see below) are absent or amount to less than 1/10 sky cover;

$$
\begin{aligned}
1 & =\mathrm{Cu} ; \\
2 & =\mathrm{Cb} ; \\
3 & =\text { not used; } \\
4 & =\text { Cu and } \mathrm{Cb} ; \\
5-7 & =\text { not used; }
\end{aligned}
$$

$8=$ low-level cloud presence and type cannot be determined due to fog or snowstorm;

$9=$ complete absence of clouds or, in the case of translucent fog, clear in the zenith (if CLDL1F =0; otherwise the observation is missing);

CLDL1F is the low-level cloud type quality flag for the first low-level cloud group ( 0 indicates a valid observation; 9 indicates a suspect or missing observation);

CLDL2 is the second of three code groups for describing low-level cloud type. Low-level clouds are defined as those with bases lower than $2000 \mathrm{~m}$; they include stratocumulus $(\mathrm{Sc})$, stratus ( $\mathrm{St}$ ), nimbostratus $(\mathrm{Ns})$, cumulus $(\mathrm{Cu})$, and cumulonimbus $(\mathrm{Cb})$ clouds. Codes have the following meanings:

0 = cloud type is not indicated, but high- or mid-level clouds observed, with total cloud amount ranging anywhere from $1 / 10$ to overcast; low-level clouds of the CLDL2 group (see below) are absent or amount to less than 1/10 sky cover;

$1=\mathrm{St}$;

2 = Sc;

3 = not used;

$4=$ St and Sc;

5-7 = not used;

$8=$ low-level cloud presence and type cannot be determined due to fog or snowstorm;

$9=$ complete absence of clouds or, in the case of translucent fog, clear in the zenith (if CLDL2F $=0$; otherwise the observation is missing);

CLDL2F is the low-level cloud type quality flag for the second low-level cloud group. ( 0 indicates a valid observation; 9 indicates a suspect or missing observation.);

CLDL3 is the third of three code groups for describing low-level cloud type. Low-level clouds are defined as those with bases lower than $2000 \mathrm{~m}$; they include stratocumulus ( $\mathrm{Sc})$, stratus $(\mathrm{St})$, nimbostratus $(\mathrm{Ns})$, cumulus $(\mathrm{Cu})$, and cumulonimbus $(\mathrm{Cb})$ clouds. Codes have the following meanings:

$0=$ cloud type is not indicated, but high- or mid-level clouds observed, with total cloud amount ranging anywhere from $1 / 10$ 
to overcast; low-level clouds of the CLDL3 group (see below) are absent or amount to less than $1 / 10$ sky cover;

1 = not used;

2 = Ns;

3 = fractostratus (Fs) and fractocumulus ( $\mathrm{Fc}$ ) of bad weather (also known as scud);

4-5 = not used;

$6=$ Ns and Frnb;

7 = not used;

$8=$ low-level cloud presence and type cannot be determined due to fog or snowstorm;

$9=$ complete absence of clouds or, in the case of translucent fog, clear in the zenith (if CLDL3F $=0$; otherwise the observation is missing);

CLDL3F is the low-level cloud type quality flag for the third low-level cloud group ( 0 indicates a valid observation; 9 indicates a suspect or missing observation);

WIR is the wind irregularity characteristic. It is a coded value used to describe the wind speed as steady or gusty and the wind direction as constant or variable. The wind is considered to be steady if its speed remains essentially constant over the course of two minutes; otherwise it is considered gusty. The wind direction is considered constant if over the course of two minutes it varies within one compass point; otherwise it is considered to be variable. Observations of this variable are only present in the 6-hourly data records (i.e., in the pre-1966 data). The 3-hourly records (1966 onward) contain a value of 9 to indicate missing data. For the pre1966 data, a value of 9 is also used to indicate a missing value. Codes for observations have the following meanings:

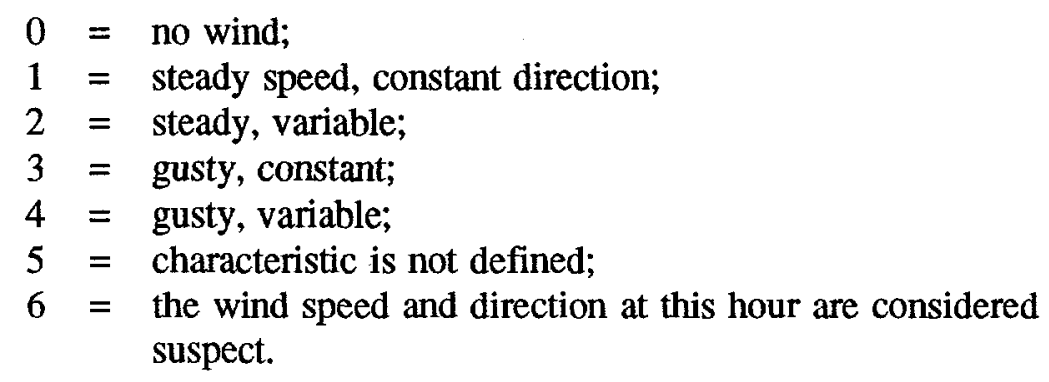

WIRF is the wind irregularity characteristic quality flag $(0$ indicates a valid observation; 9 indicates a suspect or missing observation). 



\section{VERIFICATION OF DATA TRANSPORT}

The data files contained in this NDP can be read by using the FORTRAN and SAS ${ }^{10}$ programs provided. Users should verify that the data have been correctly transported to their systems by visually examining each data file, where practical. To facilitate the visual inspection process, partial listings of each data file are provided in Tables 4-8. Each of these tables contains the first five and last five records of the data file.

Table 4. Partial listing of the file station.inv (File 12)

First five records of the file:

$\begin{array}{ll}20674 & \text { OSTROV DIKSON } \\ 20891 & \text { HATANGA } \\ 21946 & \text { COKURDAH } \\ 21982 & \text { OSTROV VRANGELJA } \\ 22113 & \text { MURMANSK }\end{array}$

73.50

71.98

70.62

70.97

68.97

$$
80.40
$$

102.47

147.88

$-178.37$

33.05

42.0

30.0

0.0

2.0

57.0

$01 / 1936 \quad 12 / 1984$

$01 / 193612 / 1984$

$08 / 1944 \quad 12 / 1984$

$01 / 193612 / 1984$

$01 / 1936 \quad 12 / 1984$
Last five records of the file:

$\begin{array}{ll}38927 & \text { TERMEZ } \\ 38933 & \text { KURGAN-TJUBE } \\ 38954 & \text { HOROG } \\ 38974 & \text { SERAHS } \\ 38987 & \text { KUSKA }\end{array}$

38927 TERMEZ

38933 KURGAN-TJUBE

38974 SERAHS

38987 KUSKA

$$
\begin{array}{rr}
67.27 & 309.0 \\
68.78 & 427.0 \\
71.50 & 2077.0 \\
61.22 & 275.0 \\
62.35 & 625.0
\end{array}
$$

Table 5. Partial listing of the file gaps.dat (File 13)

First five records of the file:

$\begin{array}{ll}20891 & 07 / 1944-06 / 1946 \\ 21946 & 08 / 1947-09 / 1947 \\ 21982 & 10 / 1943 \\ 22602 & 03 / 1937 \\ 22602 & 05 / 1937\end{array}$

Last five records of the file:
38954
38974
38974
38974
38987
$12 / 1937$
$10 / 1937-12 / 1937$
$10 / 1938$
$12 / 1938$
$07 / 1941$ 
Table 6. Partial listing of the file timezone.dat (File 14)

First five records of the file:

$\begin{array}{ll}20674 & 07 \\ 20891 & 08 \\ 21946 & 11 \\ 21982 & 13 \\ 22113 & 03\end{array}$

Last five records of the file:

3892706

3893306

$38954 \quad 06$

3897405

3898705

Table 7. Partial listing of the file station.his (File 15)

First five records of the file:

$\begin{array}{llrrrrr}20674 & \text { MOVE } & 1938 & -9 & -9 & 0 & -99 \\ 20674 & \text { PRCP } & 1953 & 3 & 2 & & \\ 20674 & \text { MOVE } & 1960 & -9 & -9 & 0 & -99 \\ 20891 & \text { MOVE } & 1951 & 1 & 12 & 1 & \text { SSW } \\ 20891 & \text { PRCP } & 1953 & 12 & 1 & & \end{array}$

Last five records of the file:

$\begin{array}{lllrrrr}38987 & \text { MOVE } & 1904 & 4 & -9 & -9 & -99 \\ 38987 & \text { MOVE } & 1910 & -9 & -9 & -9 & -99 \\ 38987 & \text { MOVE } & 1913 & 8 & -9 & -9 & -99 \\ 38987 & \text { MOVE } & 1927 & 5 & -9 & -9 & -99 \\ 38987 & \text { PRCP } & 1953 & 1 & 4 & & \end{array}$




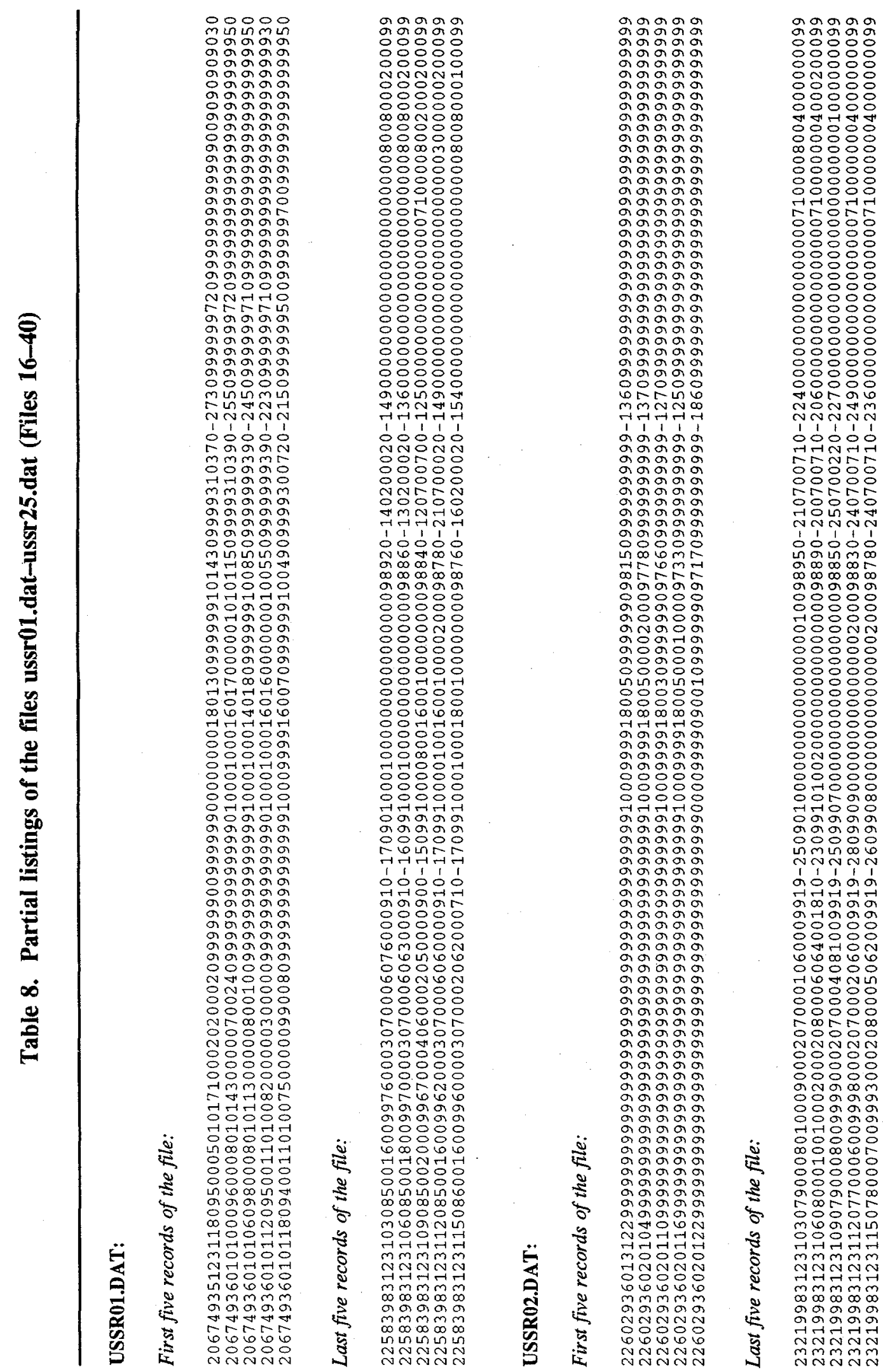




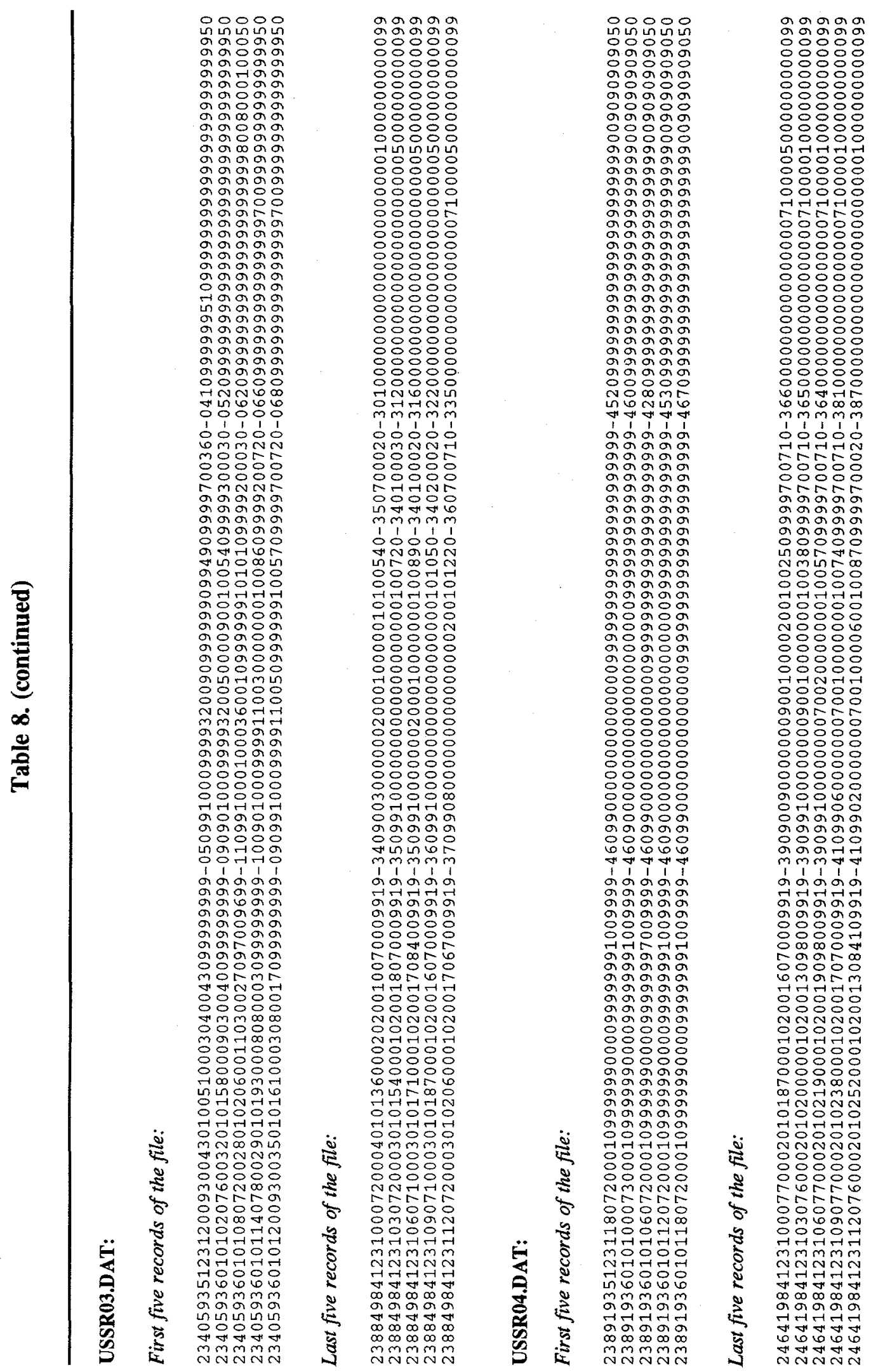




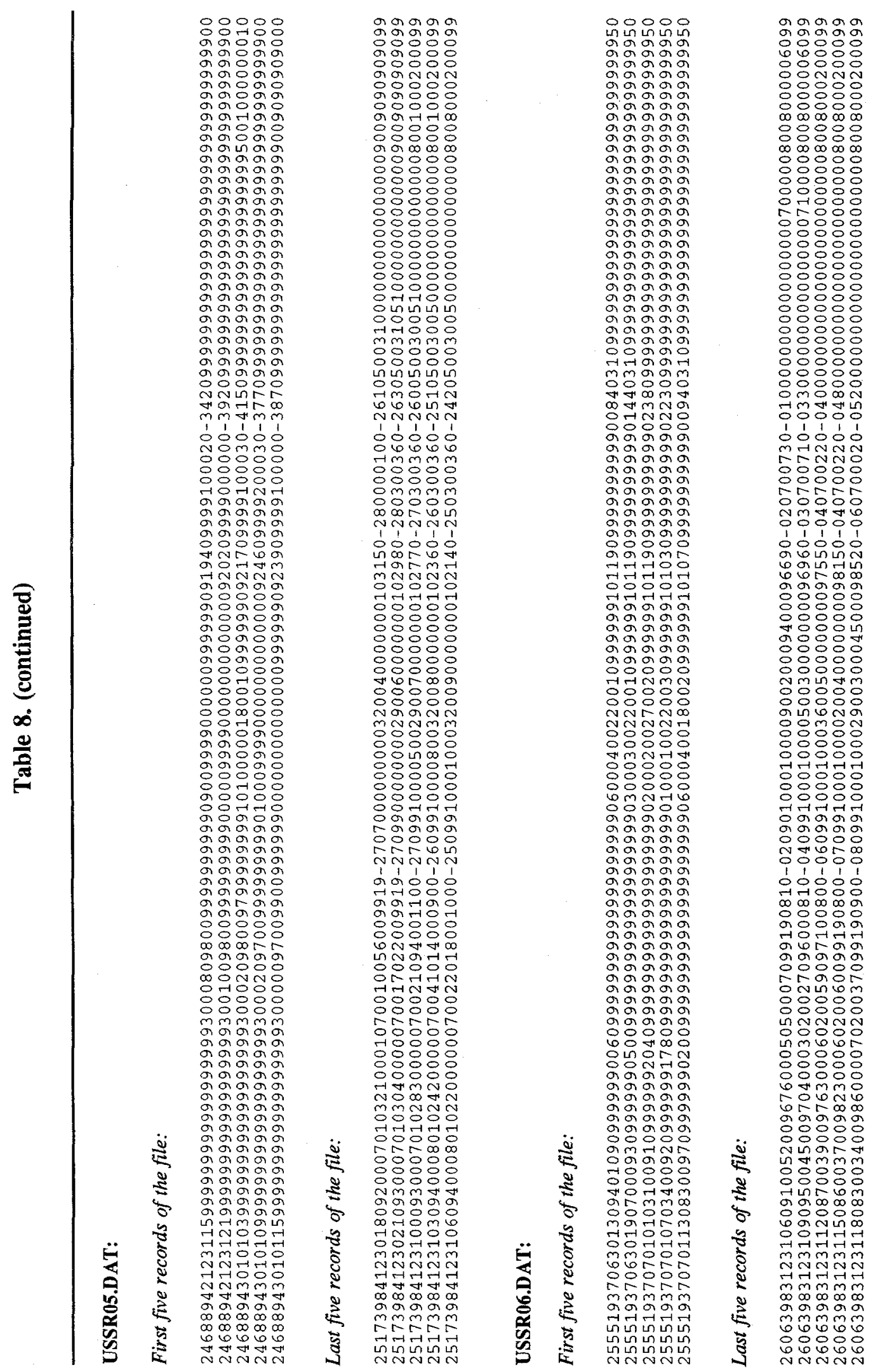




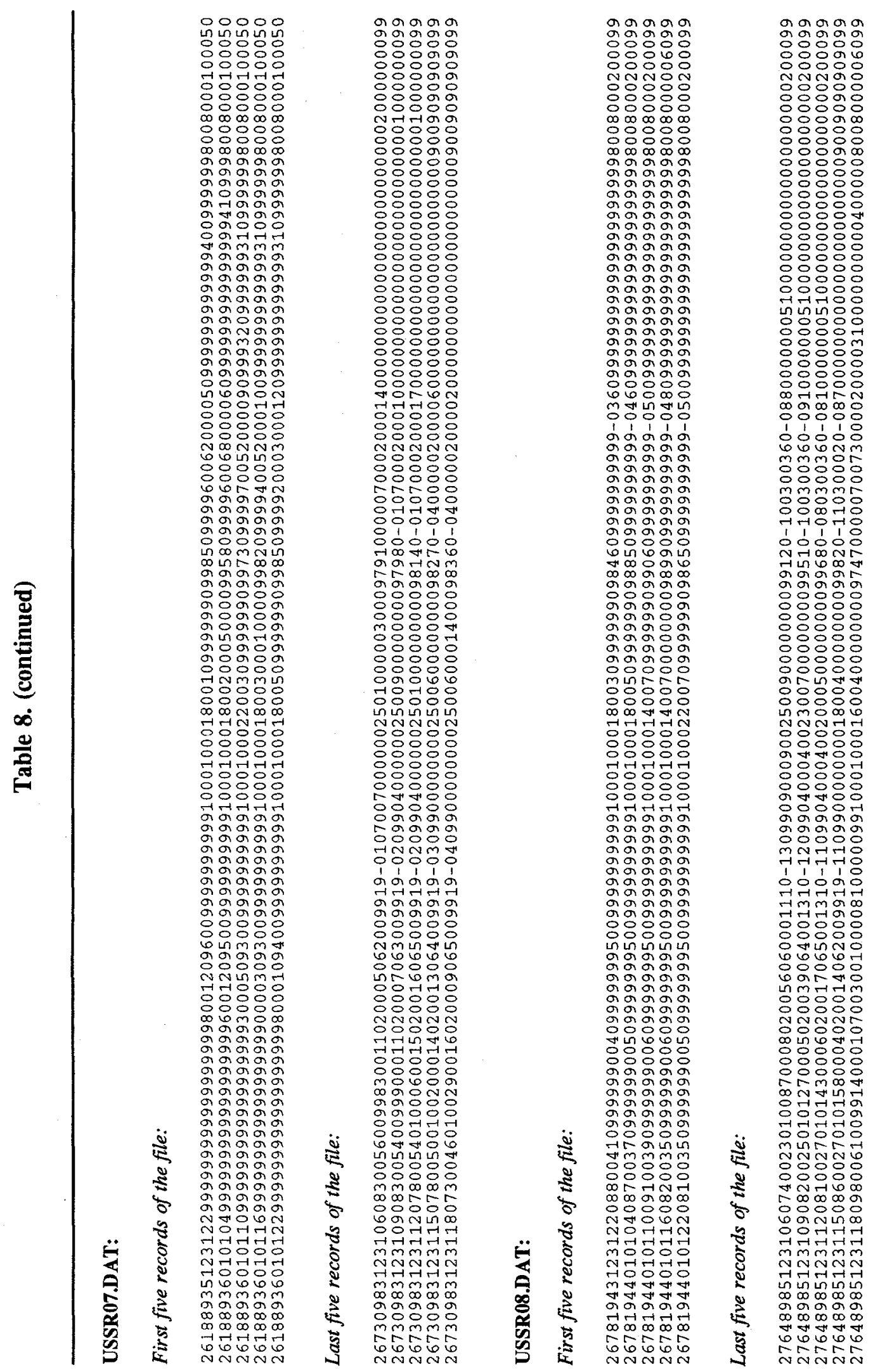




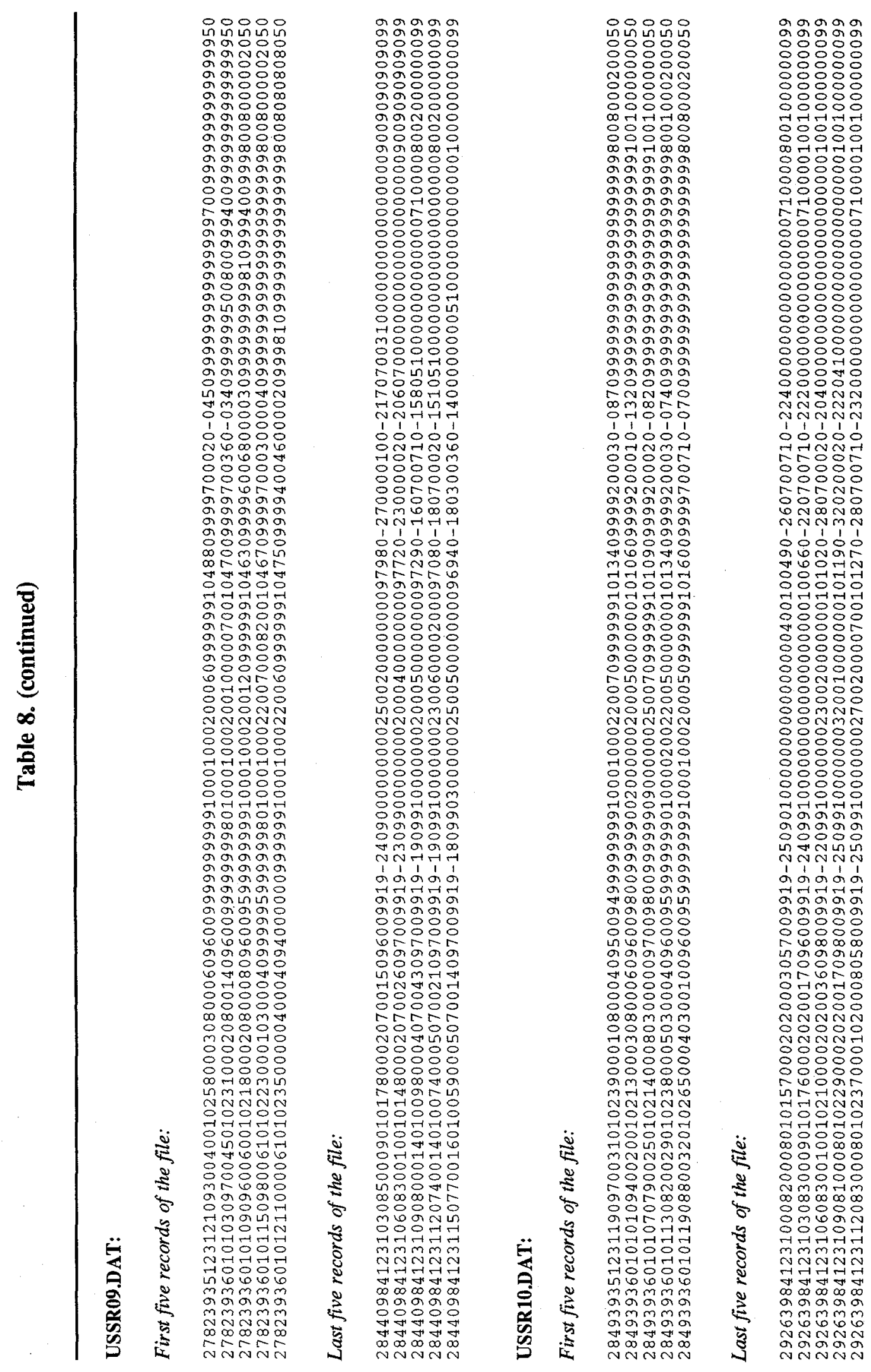




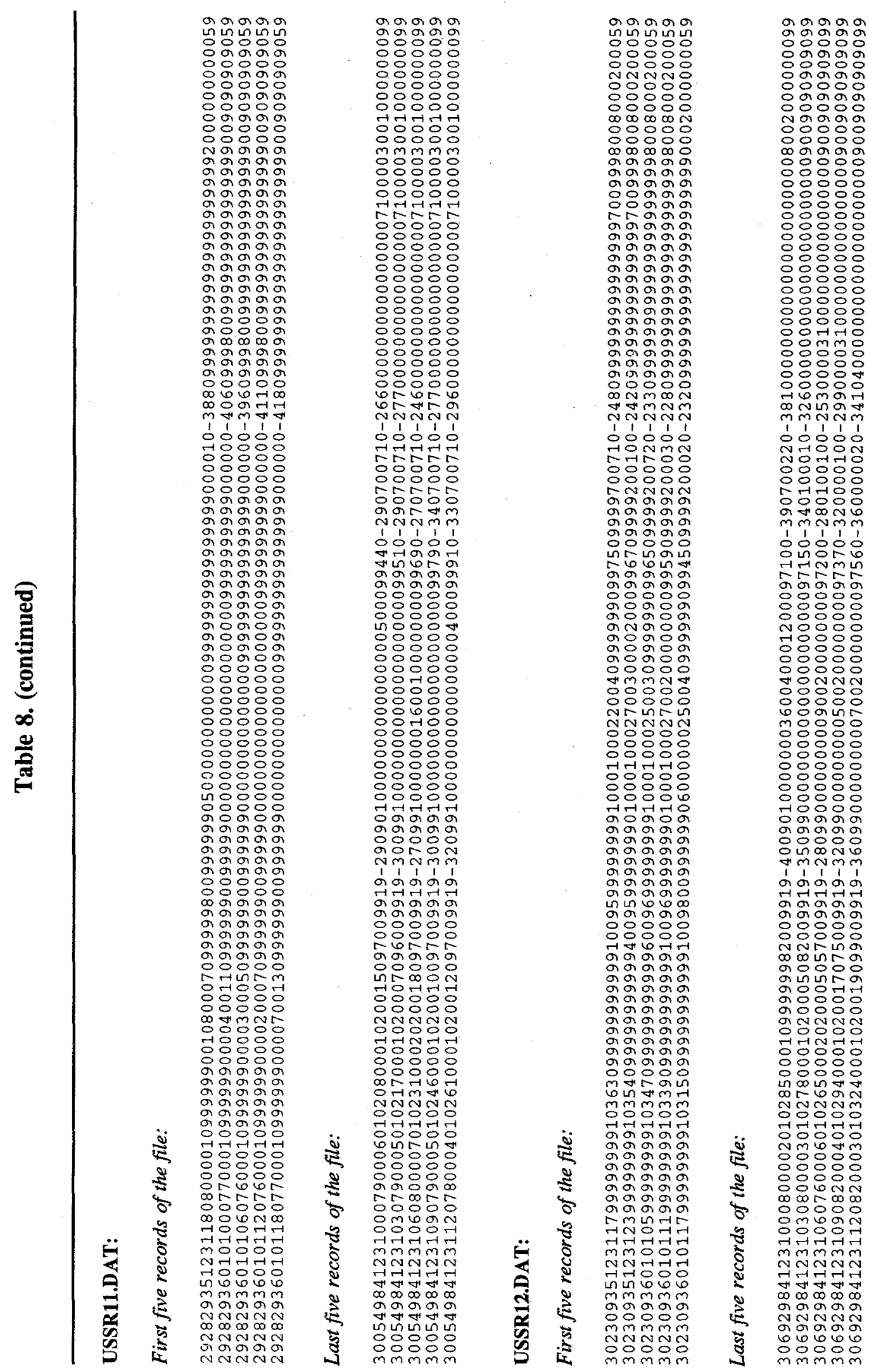




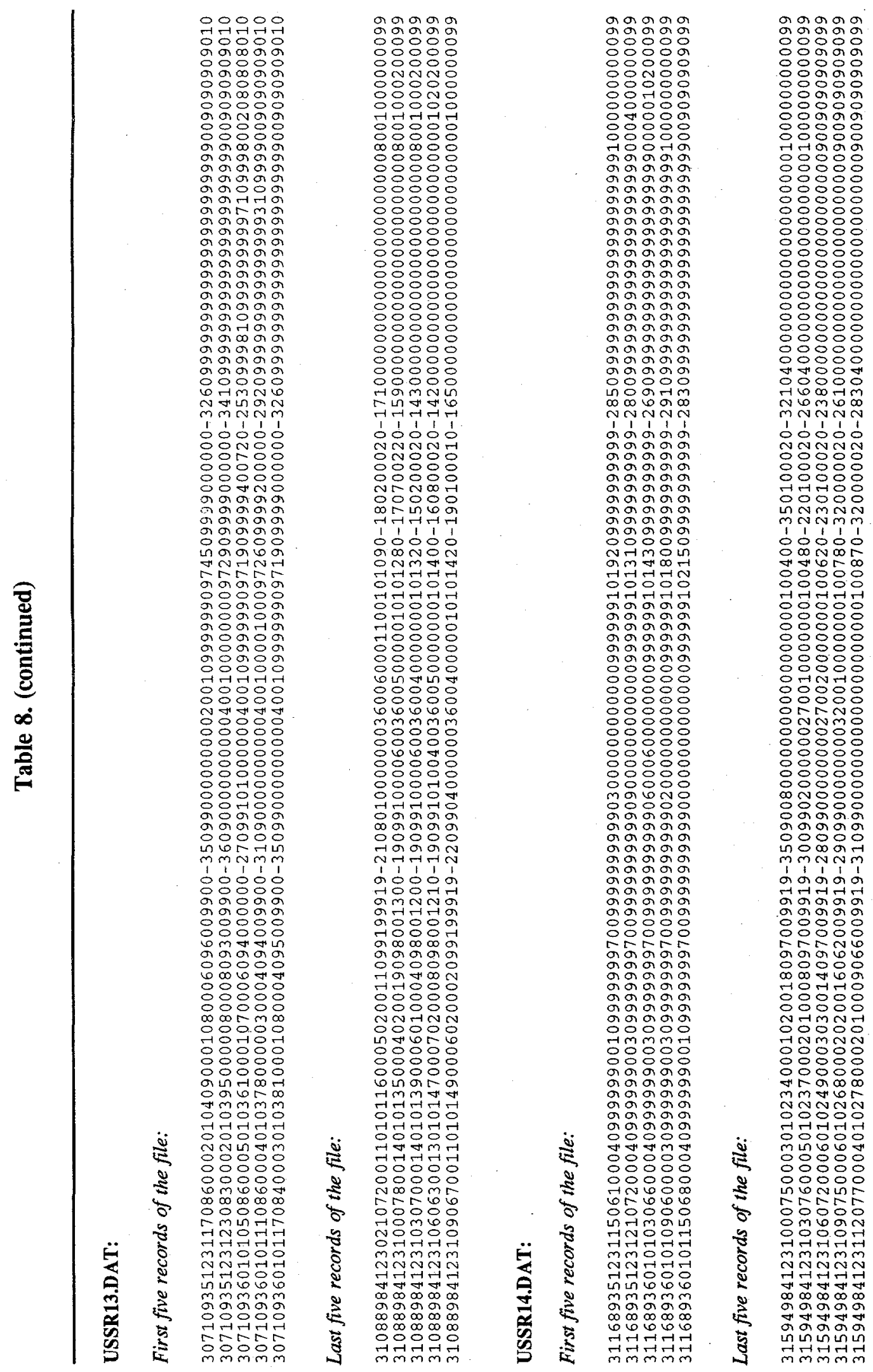




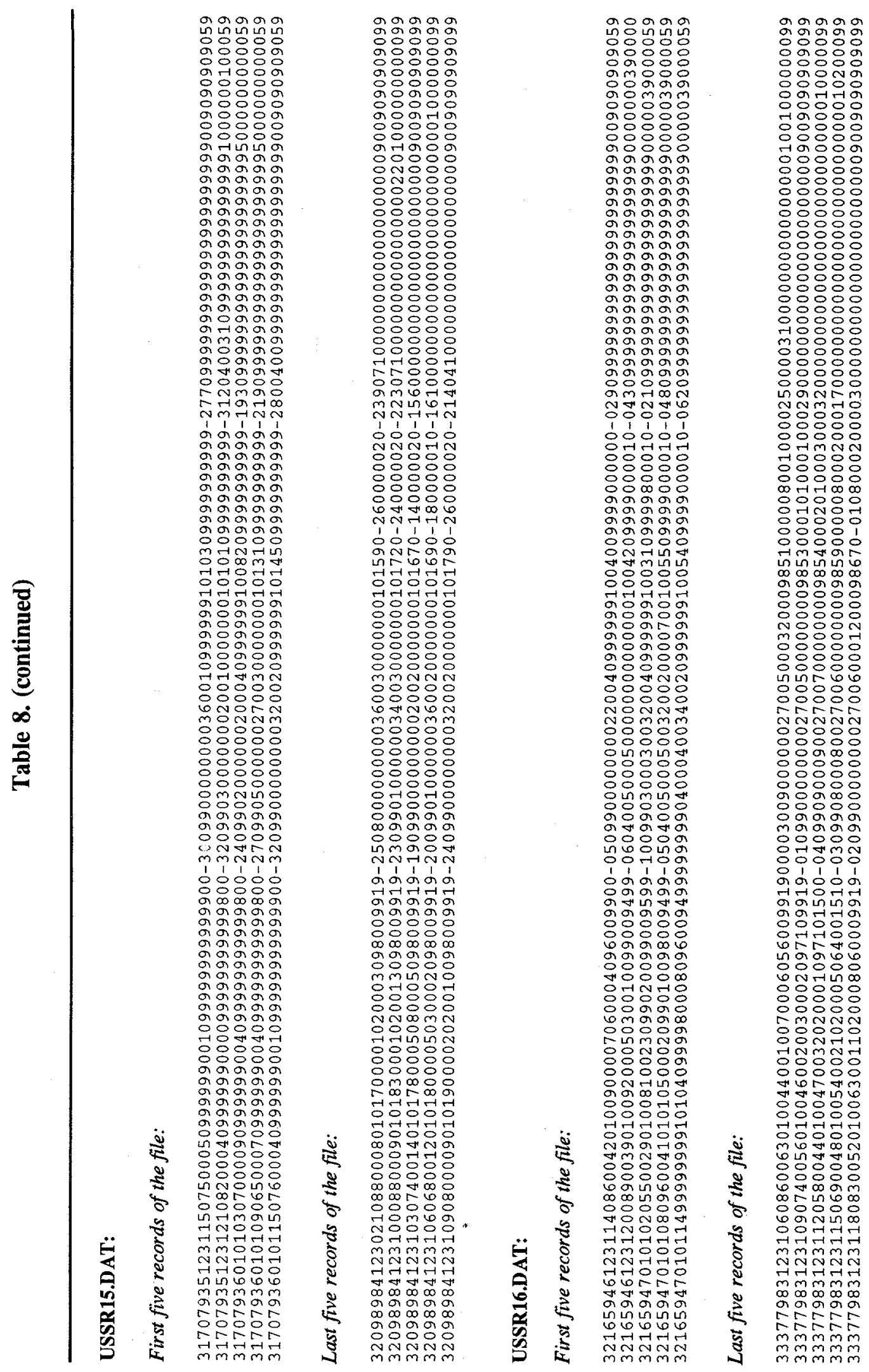




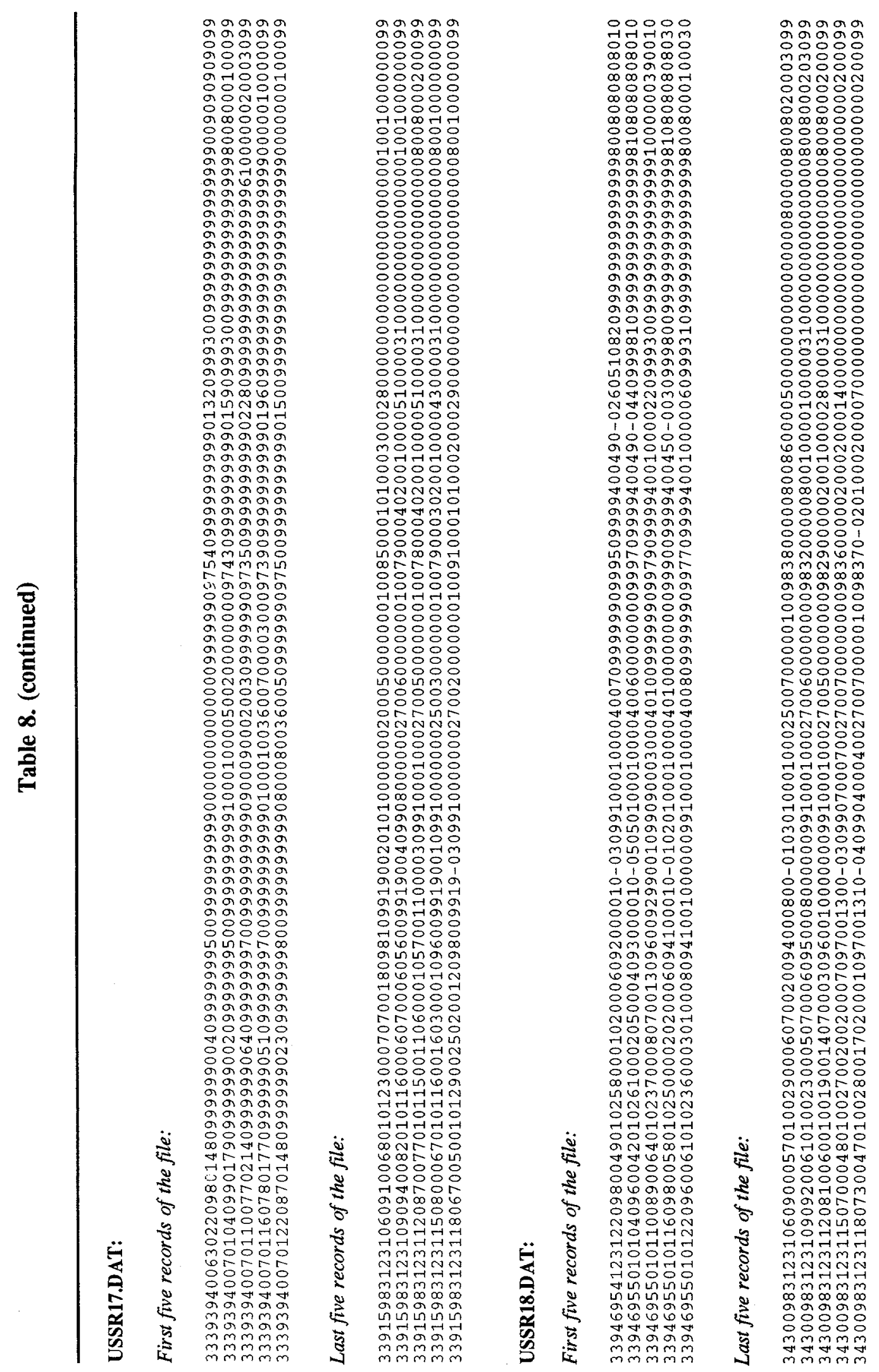




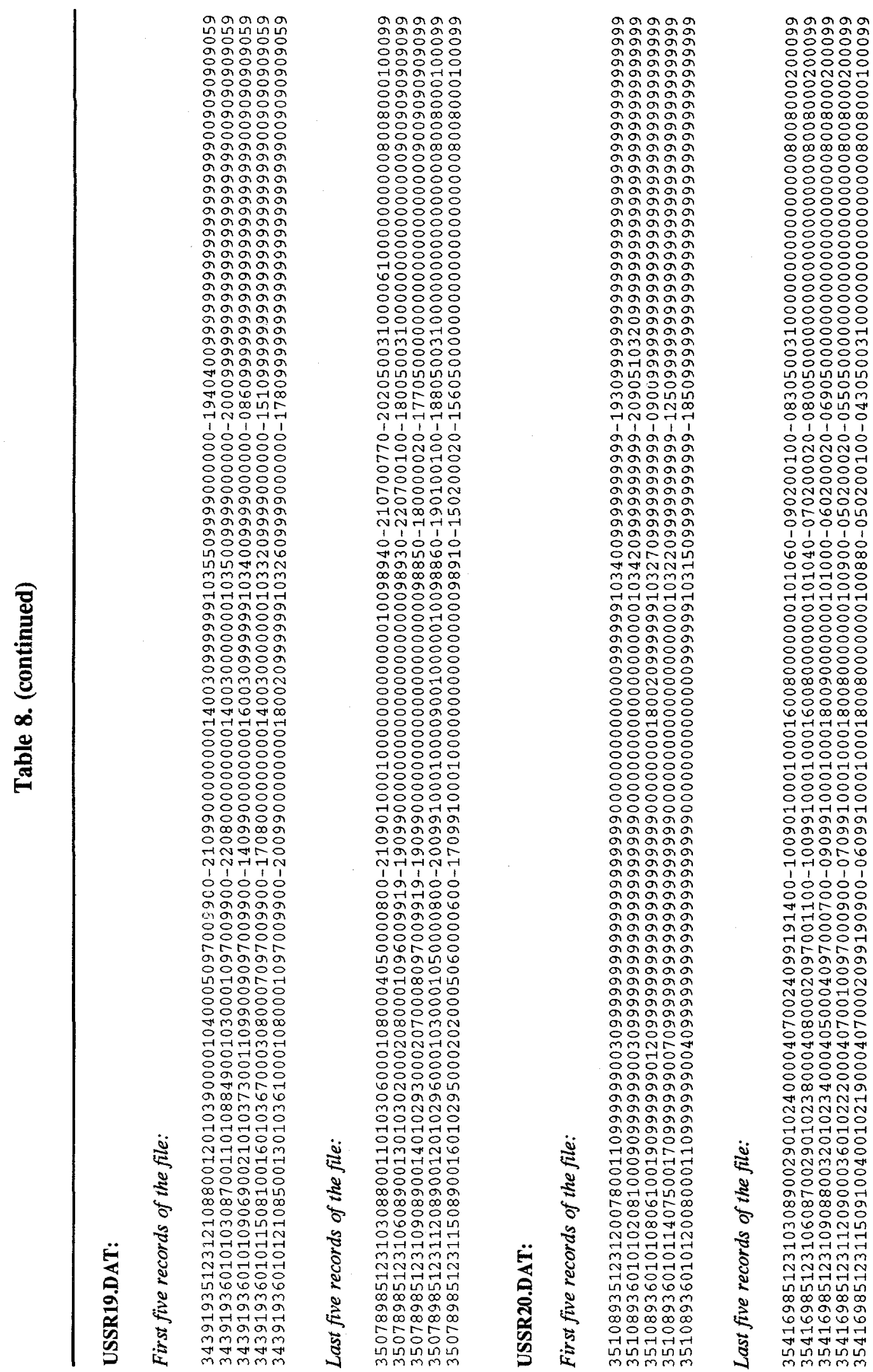




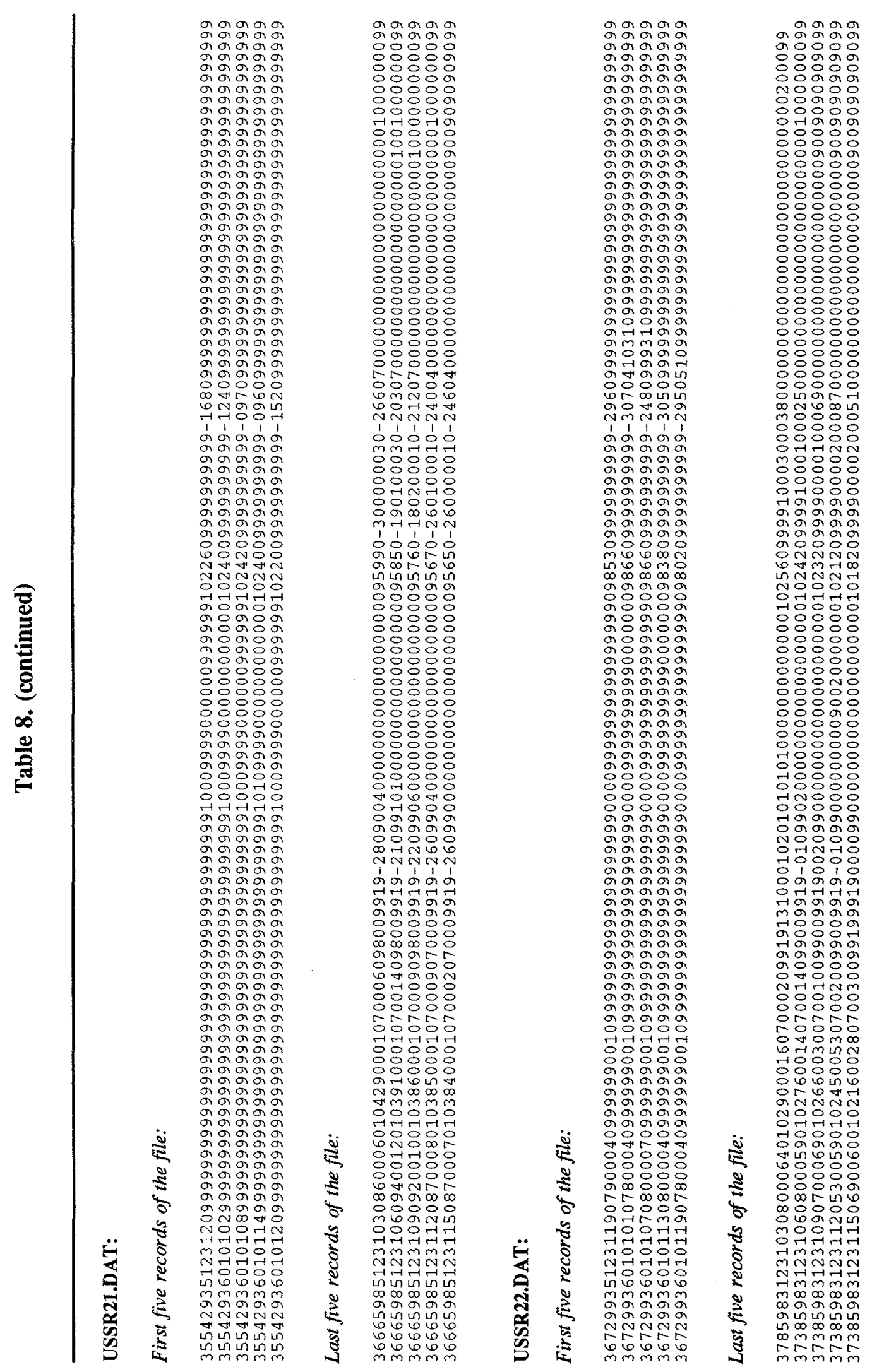




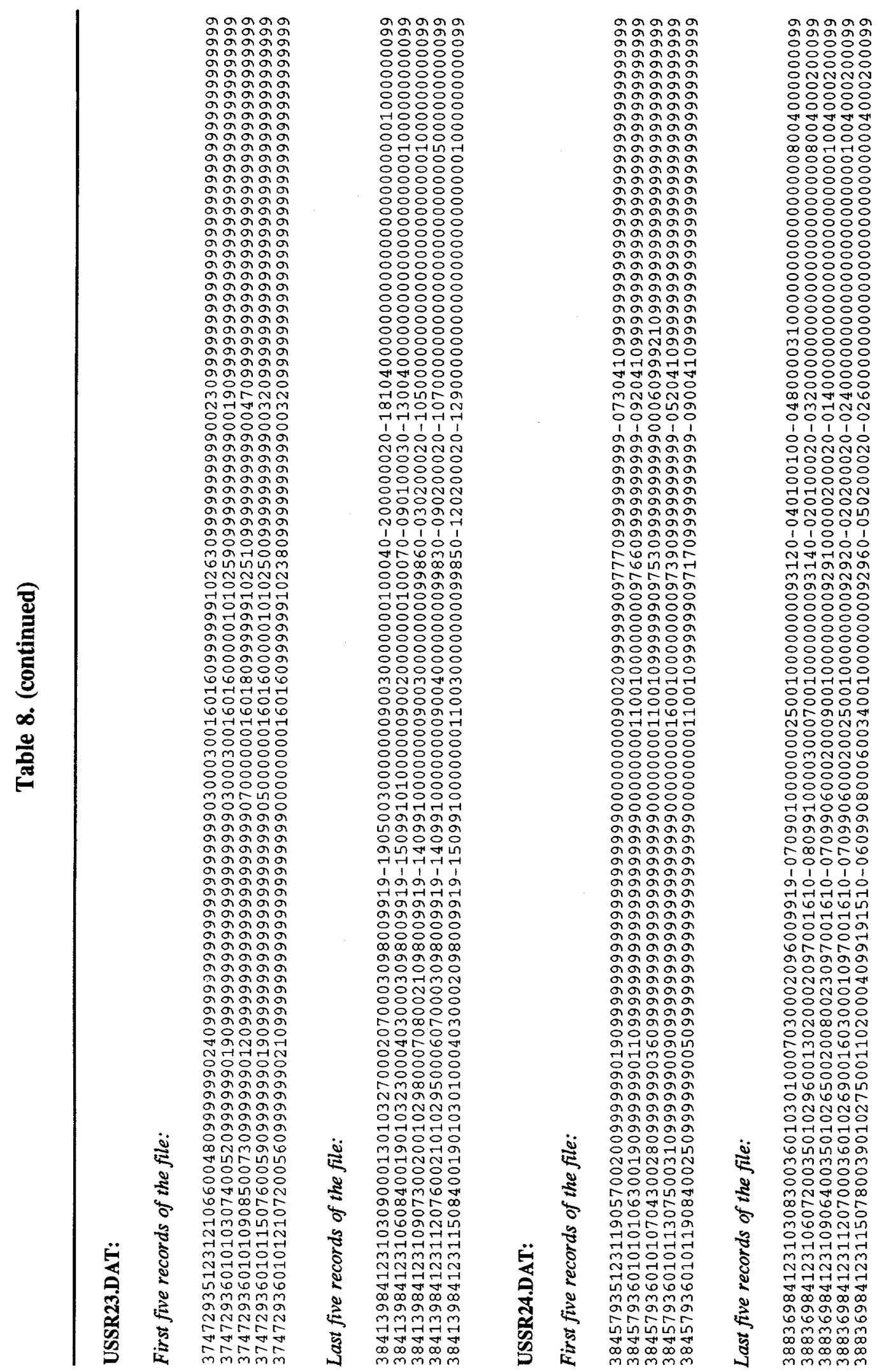




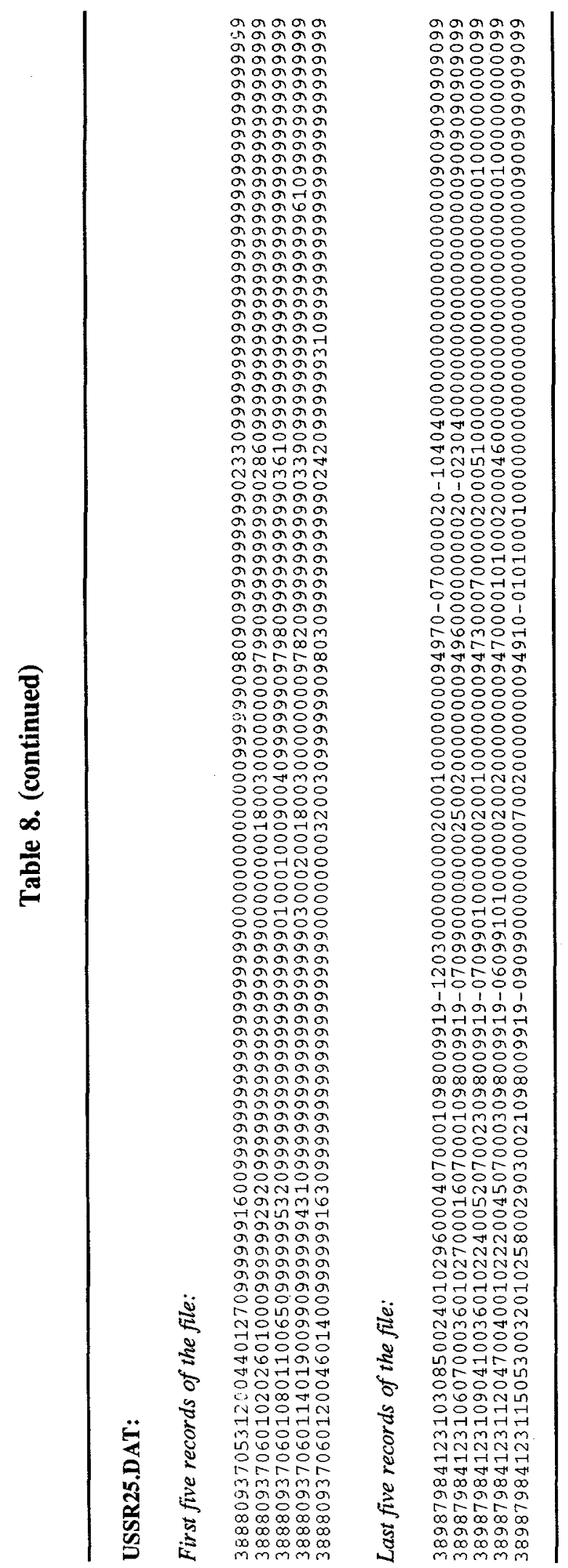




\section{APPENDICES}


APPENDIX A

STATION HISTORIES 



\section{Station Histories}

This appendix contains a list of all station history information for each of the 223 stations. The meanings of the column headings on each page are as follows:

WMO No. is the WMO No. of the station.

Type is the type of change indicated by this entry. The possible values of Type are as follows:

$$
\begin{aligned}
\text { PRCP = } & \text { rain gauge replacement (i.e., change from old-type gauge to } \\
& \text { Tretyakov-type gauge). Each station will have only one PRCP entry. } \\
& \text { In this type of entry, Distance and Direction (described below) have } \\
& \text { no meaning and thus are coded as blanks. } \\
\text { MOVE = } & \text { station relocation. Each station will have at least one MOVE entry. } \\
& \text { If a station moved on more than one occasion, then separate entries } \\
& \text { are included for each relocation. If a station never moved, then that } \\
& \text { station will have only one MOVE entry; in this entry, Year, Month, } \\
& \text { Day, Distance, and Direction (described below) are all coded as } \\
& \text { missing. }
\end{aligned}
$$

Year is the year in which the change took place. Missing years are coded as -999 .

Month is the month in which the change took place. Missing months are coded as -9 .

Day is the day on which the change took place. Missing days are coded as -9 .

Distance is the distance (in kilometers) that the station was moved. Missing distances are coded as -9 . A distance of zero indicates that the station moved less than one kilometer. Distance only applies to station relocation entries (i.e., lines in which Type $=$ MOVE). In rain gauge replacement entries (i.e., lines in which Type $=$ PRCP), Distance has no meaning and thus is coded as blanks.

Direction is the direction in which the station was moved (e.g., $\mathrm{N}=$ north, $\mathrm{SE}=$ southeast). Missing directions are coded as -99 . Direction only applies to station relocation entries (i.e., lines in which Type $=$ MOVE). In rain gauge replacement entries (i.e., lines in which Type $=$ PRCP), Direction has no meaning and thus is coded as blanks. 



\begin{tabular}{|c|c|c|c|c|c|c|}
\hline WMO No. & Type & Year & Month & Day & Distance & Direction \\
\hline 20674 & MOVE & 1938 & -9 & -9 & 0 & -99 \\
\hline 20674 & PRCP & 1953 & 3 & 2 & & \\
\hline 20674 & MOVE & 1960 & -9 & -9 & 0 & -99 \\
\hline 20891 & MOVE & 1951 & 1 & 12 & 1 & SSW \\
\hline 20891 & PRCP & 1953 & 12 & 1 & & \\
\hline 21946 & PRCP & 1954 & 9 & 17 & & \\
\hline 21946 & MOVE & 1955 & 5 & -9 & 1 & $\mathrm{NE}$ \\
\hline 21982 & MOVE & 1929 & 9 & 2 & 0 & $\mathbf{E}$ \\
\hline 21982 & MOVE & 1934 & 9 & 1 & 0 & $\bar{W}$ \\
\hline 21982 & MOVE & 1940 & 6 & 4 & 0 & $\mathrm{E}$ \\
\hline 21982 & PRCP & 1953 & 9 & 20 & & \\
\hline 22113 & MOVE & 1924 & 10 & -9 & 3 & $S$ \\
\hline 22113 & MOVE & 1934 & 11 & -9 & 1 & SE \\
\hline 22113 & PRCP & 1953 & 1 & 1 & & \\
\hline 22217 & PRCP & 1953 & 1 & 1 & & \\
\hline 22217 & MOVE & 1960 & 10 & -9 & 5 & NW \\
\hline 22522 & MOVE & 1925 & 6 & -9 & 0 & NE \\
\hline 22522 & MOVE & 1933 & 6 & 30 & 1 & $\mathbf{N}$ \\
\hline 22522 & PRCP & 1956 & 2 & 15 & & \\
\hline 22550 & MOVE & 1935 & 8 & 1 & 1 & $\mathbf{N}$ \\
\hline 22550 & MOVE & 1943 & 6 & 16 & 0 & $\mathrm{E}$ \\
\hline 22550 & PRCP & 1953 & 1 & 1 & & \\
\hline 22550 & MOVE & 1963 & 11 & -9 & 2 & $\mathrm{E}$ \\
\hline 22583 & MOVE & 1924 & -9 & -9 & 0 & $\mathrm{SE}$ \\
\hline 22583 & MOVE & 1935 & 8 & 23 & 0 & SE \\
\hline 22583 & PRCP & 1951 & 6 & 1 & & \\
\hline 22602 & MOVE & 1928 & -9 & -9 & 2 & $S$ \\
\hline 22602 & MOVE & 1930 & -9 & -9 & 1 & $\mathbf{N}$ \\
\hline 22602 & MOVE & 1932 & -9 & -9 & 0 & $\mathbf{E}$ \\
\hline 22602 & MOVE & 1934 & -9 & -9 & 0 & SW \\
\hline 22602 & PRCP & 1951 & 9 & -9 & & \\
\hline 22602 & MOVE & 1965 & 6 & -9 & 0 & W \\
\hline 22641 & MOVE & 1897 & 8 & -9 & 0 & -99 \\
\hline
\end{tabular}




\begin{tabular}{|c|c|c|c|c|c|c|}
\hline WMO No. & Type & Year & Month & Day & Distance & Direction \\
\hline 22641 & MOVE & 1900 & 5 & -9 & 0 & -99 \\
\hline 22641 & MOVE & 1926 & 9 & 15 & 0 & $\mathbf{N}$ \\
\hline 22641 & PRCP & 1953 & 1 & 15 & & \\
\hline 22802 & MOVE & 1948 & 11 & -9 & 3 & NE \\
\hline 22802 & MOVE & 1951 & 10 & -9 & 0 & $\mathrm{E}$ \\
\hline 22802 & PRCP & 1954 & 8 & -9 & & \\
\hline 22802 & MOVE & 1957 & 12 & -9 & 0 & W \\
\hline 22820 & PRCP & 1949 & 6 & 23 & & \\
\hline 22820 & MOVE & 1954 & 6 & -9 & 1 & $\mathrm{NE}$ \\
\hline 22837 & MOVE & 1914 & 11 & -9 & 0 & -99 \\
\hline 22837 & MOVE & 1932 & 9 & 30 & 0 & -99 \\
\hline 22837 & MOVE & 1937 & -9 & -9 & 0 & $\mathbf{E}$ \\
\hline 22837 & MOVE & 1949 & -9 & -9 & 0 & NW \\
\hline 22837 & PRCP & 1955 & 6 & -9 & & \\
\hline 22837 & MOVE & 1970 & 5 & -9 & 0 & NW \\
\hline 22887 & PRCP & 1951 & 8 & 31 & & \\
\hline 22887 & MOVE & 1957 & -9 & -9 & 0 & $S$ \\
\hline 22887 & MOVE & 1969 & 7 & -9 & 4 & $\mathbf{E}$ \\
\hline 22887 & MOVE & 1971 & 1 & -9 & 1 & SE \\
\hline 22887 & MOVE & 1982 & 6 & -9 & 1 & NW \\
\hline 23146 & MOVE & 1951 & 8 & 21 & 0 & -99 \\
\hline 23146 & PRCP & 1953 & 10 & 2 & & \\
\hline 23146 & MOVE & 1960 & 12 & -9 & 0 & -99 \\
\hline 23146 & MOVE & 1976 & 11 & -9 & 0 & W \\
\hline 23205 & MOVE & 1927 & 6 & 24 & 2 & SW \\
\hline 23205 & MOVE & 1927 & 9 & -9 & 0 & $\mathbf{S}$ \\
\hline 23205 & MOVE & 1941 & 8 & 26 & 2 & SW \\
\hline 23205 & MOVE & 1947 & 11 & -9 & 1 & $\mathbf{E}$ \\
\hline 23205 & PRCP & 1954 & 9 & 2 & & \\
\hline 23205 & MOVE & 1959 & 10 & 15 & 1 & SE \\
\hline 23205 & MOVE & 1984 & 11 & -9 & 1 & SW \\
\hline 23219 & MOVE & 1937 & 8 & 9 & 0 & $\mathrm{NE}$ \\
\hline 23219 & PRCP & 1955 & 9 & 25 & & \\
\hline 23405 & MOVE & 1899 & 10 & -9 & 0 & $S$ \\
\hline 23405 & MOVE & 1904 & -9 & -9 & 1 & NW \\
\hline
\end{tabular}




\begin{tabular}{|c|c|c|c|c|c|c|}
\hline WMO No. & Type & Year & Month & Day & Distance & Direction \\
\hline 23405 & MOVE & 1915 & 8 & 14 & 0 & -99 \\
\hline 23405 & MOVE & 1918 & 11 & 21 & 0 & W \\
\hline 23405 & MOVE & 1930 & 6 & -9 & 0 & $\mathrm{E}$ \\
\hline 23405 & PRCP & 1952 & 6 & 26 & & \\
\hline 23418 & PRCP & 1952 & 8 & 1 & & \\
\hline 23418 & MOVE & 1965 & 10 & 14 & 0 & $\mathbf{S}$ \\
\hline 23472 & MOVE & 1898 & 6 & -9 & 0 & -99 \\
\hline 23472 & MOVE & 1911 & 9 & -9 & 0 & -99 \\
\hline 23472 & MOVE & 1915 & 6 & -9 & 1 & NW \\
\hline 23472 & PRCP & 1953 & 1 & 1 & & \\
\hline 23472 & MOVE & 1953 & 8 & 10 & 2 & NW \\
\hline 23472 & MOVE & 1959 & 8 & -9 & 4 & SE \\
\hline 23631 & MOVE & 1893 & -9 & -9 & 0 & -99 \\
\hline 23631 & MOVE & 1898 & -9 & -9 & 0 & -99 \\
\hline 23631 & MOVE & 1937 & 10 & 13 & 0 & $S$ \\
\hline 23631 & PRCP & 1954 & 6 & -9 & & \\
\hline 23711 & MOVE & 1892 & 10 & 8 & 1 & SE \\
\hline 23711 & MOVE & 1901 & 6 & -9 & 0 & -99 \\
\hline 23711 & MOVE & 1930 & 9 & -9 & 0 & -99 \\
\hline 23711 & MOVE & 1935 & 10 & -9 & 0 & $\mathbf{N}$ \\
\hline 23711 & MOVE & 1940 & 6 & 12 & 3 & SE \\
\hline 23711 & PRCP & 1952 & 11 & 25 & 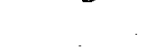 & \\
\hline 23711 & MOVE & 1960 & 3 & 4 & 1 & $\mathbf{E}$ \\
\hline 23711 & MOVE & 1965 & 4 & 20 & 8 & $\mathbf{N}$ \\
\hline 23724 & MOVE & 1935 & 1 & 8 & 1 & SW \\
\hline 23724 & PRCP & 1955 & 9 & -9 & & \\
\hline 23724 & MOVE & 1963 & 10 & 10 & 0 & NNW \\
\hline 23804 & MOVE & 1894 & -9 & -9 & 0 & $\mathrm{NE}$ \\
\hline 23804 & MOVE & 1925 & -9 & -9 & 0 & $\mathbf{W}$ \\
\hline 23804 & MOVE & 1947 & 5 & 24 & 0 & NW \\
\hline 23804 & PRCP & 1954 & 9 & 13 & & \\
\hline 23804 & MOVE & 1965 & 1 & 11 & 1 & SW \\
\hline 23804 & MOVE & 1969 & -9 & -9 & 1 & $\mathbf{S}$ \\
\hline 23804 & MOVE & 1982 & 2 & 1 & 4 & NW \\
\hline 23849 & MOVE & 1887 & -9 & -9 & -9 & -99 \\
\hline 23849 & MOVE & 1911 & -9 & -9 & -9 & -99 \\
\hline
\end{tabular}




\begin{tabular}{|c|c|c|c|c|c|c|}
\hline WMO No. & Type & Year & Month & Day & Distance & Direction \\
\hline 23849 & MOVE & 1939 & 7 & 10 & 5 & $\mathbf{E}$ \\
\hline 23849 & PRCP & 1950 & -9 & -9 & & \\
\hline 23849 & MOVE & 1961 & 12 & 25 & 2 & WNW \\
\hline 23884 & MOVE & 1949 & 6 & 29 & 1 & W \\
\hline 23884 & PRCP & 1954 & 9 & 3 & & \\
\hline 23884 & MOVE & 1955 & 1 & 1 & 7 & SW \\
\hline 23884 & MOVE & 1957 & 10 & 15 & 2 & E \\
\hline 23891 & PRCP & 1953 & 7 & 24 & & \\
\hline 23891 & MOVE & 1957 & 6 & 19 & 0 & -99 \\
\hline 23921 & PRCP & 1952 & 7 & -9 & & \\
\hline 23921 & MOVE & 1959 & 10 & -9 & 4 & $\mathbf{S}$ \\
\hline 23933 & MOVE & 1930 & -9 & -9 & 0 & -99 \\
\hline 23933 & MOVE & 1935 & 8 & -9 & 0 & -99 \\
\hline 23933 & PRCP & 1955 & 6 & -9 & & \\
\hline 23933 & MOVE & 1961 & 6 & 25 & 0 & -99 \\
\hline 23955 & MOVE & 1954 & 9 & 29 & 2 & NW \\
\hline 23955 & PRCP & 1954 & 10 & 2 & & \\
\hline 23955 & MOVE & 1959 & 7 & 1 & 3 & NW \\
\hline 24125 & PRCP & 1955 & 8 & 1 & & \\
\hline 24125 & MOVE & 1965 & 6 & -9 & 2 & ENE \\
\hline 24266 & MOVE & 1894 & 3 & -9 & 0 & -99 \\
\hline 24266 & MOVE & 1894 & 11 & -9 & 0 & -99 \\
\hline 24266 & MOVE & 1896 & 10 & -9 & 0 & -99 \\
\hline 24266 & MOVE & 1897 & 3 & 20 & 0 & -99 \\
\hline 24266 & MOVE & 1898 & 10 & 21 & 0 & -99 \\
\hline 24266 & MOVE & 1900 & 4 & -9 & 0 & -99 \\
\hline 24266 & MOVE & 1913 & 11 & 10 & 0 & $\mathrm{NE}$ \\
\hline 24266 & MOVE & 1920 & -9 & -9 & 0 & -99 \\
\hline 24266 & MOVE & 1921 & 4 & -9 & 0 & $\mathrm{E}$ \\
\hline 24266 & MOVE & 1927 & 9 & 30 & 0 & $\mathbf{N}$ \\
\hline 24266 & MOVE & 1940 & 10 & 30 & 2 & NNE \\
\hline 24266 & MOVE & 1947 & 4 & 27 & 3 & SSE \\
\hline 24266 & PRCP & 1953 & 1 & 1 & & \\
\hline 24266 & MOVE & 1954 & 10 & 19 & 1 & $\mathrm{E}$ \\
\hline 24266 & MOVE & 1955 & 8 & 7 & 1 & $\mathbf{W}$ \\
\hline 24266 & MOVE & 1960 & 6 & 22 & 0 & $\mathrm{NE}$ \\
\hline
\end{tabular}




\begin{tabular}{|c|c|c|c|c|c|c|}
\hline WMO No. & Type & Year & Month & Day & Distance & Direction \\
\hline 24343 & PRCP & 1953 & 1 & -9 & & \\
\hline 24343 & MOVE & 1957 & 9 & 4 & 1 & NW \\
\hline 24343 & MOVE & 1960 & 9 & 9 & 0 & NW \\
\hline 24343 & MOVE & 1964 & 7 & 25 & 0 & $\mathrm{NE}$ \\
\hline 24343 & MOVE & 1973 & 6 & -9 & 0 & SE \\
\hline 24507 & PRCP & 1953 & 9 & 19 & & \\
\hline 24507 & MOVE & 1962 & 3 & 11 & 1 & NE \\
\hline 24641 & MOVE & 1898 & 5 & -9 & 0 & -99 \\
\hline 24641 & MOVE & 1899 & 9 & -9 & 0 & -99 \\
\hline 24641 & MOVE & 1929 & -9 & -9 & 0 & -99 \\
\hline 24641 & MOVE & 1939 & 8 & 1 & 0 & W \\
\hline 24641 & PRCP & 1953 & 1 & 1 & & \\
\hline 24641 & MOVE & 1956 & 11 & 10 & 10 & SE \\
\hline 24688 & MOVE & 1942 & -9 & -9 & 2 & $\mathbf{S}$ \\
\hline 24688 & PRCP & 1953 & 2 & 1 & & \\
\hline 24738 & PRCP & 1957 & 1 & 1 & & \\
\hline 24738 & MOVE & 1960 & 9 & 19 & 2 & NE \\
\hline 24738 & MOVE & 1973 & 9 & 7 & 3 & $\mathbf{N}$ \\
\hline 24817 & MOVE & 1938 & 9 & 6 & 0 & -99 \\
\hline 24817 & PRCP & 1953 & 6 & -9 & & \\
\hline 24817 & MOVE & 1953 & 9 & 11 & 0 & -99 \\
\hline 24817 & MOVE & 1956 & 11 & 10 & 0 & ESE \\
\hline 24908 & MOVE & 1935 & 5 & -9 & 0 & -99 \\
\hline 24908 & PRCP & 1953 & 1 & 15 & & \\
\hline 24908 & MOVE & 1956 & -9 & -9 & 0 & -99 \\
\hline 24908 & MOVE & 1957 & 6 & -9 & 0 & -99 \\
\hline 24944 & MOVE & 1911 & 6 & -9 & 0 & -99 \\
\hline 24944 & MOVE & 1938 & 8 & -9 & 0 & -99 \\
\hline 24944 & MOVE & 1945 & 1 & -9 & 0 & -99 \\
\hline 24944 & PRCP & 1953 & 1 & 1 & & \\
\hline 24944 & MOVE & 1958 & 8 & -9 & 0 & -99 \\
\hline 24951 & MOVE & 1937 & 7 & 4 & 0 & $\mathbf{E}$ \\
\hline 24951 & MOVE & 1942 & 10 & 3 & 7 & SE \\
\hline 24951 & MOVE & 1945 & 9 & 4 & 7 & NW \\
\hline
\end{tabular}




\begin{tabular}{|c|c|c|c|c|c|c|}
\hline WMO No. & Type & Year & Month & Day & Distance & Direction \\
\hline 24951 & PRCP & 1953 & 1 & -9 & & \\
\hline 24951 & MOVE & 1955 & 10 & 25 & 0 & $\mathbf{S}$ \\
\hline 24951 & MOVE & 1959 & 9 & 30 & 0 & $\mathbf{E}$ \\
\hline 24959 & MOVE & 1930 & 10 & -9 & 0 & -99 \\
\hline 24959 & PRCP & 1953 & 1 & 1 & & \\
\hline 24959 & MOVE & 1964 & 11 & -9 & 1 & NW \\
\hline 24966 & MOVE & 1925 & 8 & -9 & 7 & SW \\
\hline 24966 & MOVE & 1943 & 9 & 15 & 0 & -99 \\
\hline 24966 & PRCP & 1953 & 1 & 1 & & \\
\hline 25173 & MOVE & 1933 & -9 & -9 & 0 & $\mathbf{S}$ \\
\hline 25173 & PRCP & 1949 & 10 & -9 & & \\
\hline 25551 & MOVE & 1904 & -9 & -9 & 25 & $\mathbf{E}$ \\
\hline 25551 & MOVE & 1911 & -9 & -9 & 25 & W \\
\hline 25551 & MOVE & 1940 & -9 & -9 & 25 & $\mathbf{E}$ \\
\hline 25551 & MOVE & 1942 & 10 & -9 & 25 & $\mathbf{W}$ \\
\hline 25551 & PRCP & 1952 & 7 & 1 & & \\
\hline 25551 & MOVE & 1959 & 3 & -9 & 0 & $\mathrm{E}$ \\
\hline 25563 & MOVE & 1913 & -9 & -9 & 0 & -99 \\
\hline 25563 & MOVE & 1935 & 12 & 1 & 5 & NE \\
\hline 25563 & PRCP & 1951 & 12 & 18 & & \\
\hline 25594 & MOVE & 1938 & -9 & -9 & 0 & -99 \\
\hline 25594 & PRCP & 1950 & 3 & -9 & & \\
\hline 25594 & MOVE & 1960 & -9 & -9 & 0 & -99 \\
\hline 25703 & MOVE & 1941 & 12 & -9 & 2 & $\mathbf{N}$ \\
\hline 25703 & PRCP & 1954 & 1 & -9 & & \\
\hline 25744 & MOVE & 1941 & 6 & -9 & 2 & $\mathrm{SE}$ \\
\hline 25744 & MOVE & 1946 & 12 & -9 & 2 & NW \\
\hline 25744 & PRCP & 1951 & -9 & -9 & & \\
\hline 25744 & MOVE & 1964 & 8 & -9 & 8 & $S$ \\
\hline 25913 & MOVE & 1937 & 2 & 17 & 0 & -99 \\
\hline 25913 & PRCP & 1948 & 7 & 31 & & \\
\hline 25954 & MOVE & -999 & -9 & -9 & -9 & -99 \\
\hline 25954 & PRCP & 1951 & 10 & 24 & & \\
\hline
\end{tabular}


WMO No. Type

\begin{tabular}{|c|c|c|c|c|c|c|}
\hline 26038 & MOVE & -999 & -9 & -9 & -9 & -99 \\
\hline 26038 & PRCP & 1952 & 9 & 1 & & \\
\hline 26063 & MOVE & 1933 & 7 & -9 & 5 & NNW \\
\hline 26063 & PRCP & 1946 & 11 & -9 & & \\
\hline 26063 & MOVE & 1970 & 6 & -9 & 0 & W \\
\hline 26188 & MOVE & 1934 & 3 & -9 & 0 & $\mathrm{~N}$ \\
\hline 26188 & PRCP & 1954 & 6 & -9 & & \\
\hline 26231 & MOVE & 1944 & 10 & 14 & -9 & -99 \\
\hline 26231 & MOVE & 1947 & 11 & 7 & 2 & SSE \\
\hline 26231 & PRCP & 1949 & 1 & -9 & & \\
\hline 26231 & MOVE & 1964 & 12 & -9 & -9 & -99 \\
\hline 26258 & MOVE & 1910 & 3 & -9 & 1 & NW \\
\hline 26258 & MOVE & 1925 & 4 & -9 & 0 & -99 \\
\hline 26258 & MOVE & 1934 & 9 & -9 & 1 & $\mathbf{N}$ \\
\hline 26258 & MOVE & 1944 & 8 & -9 & 3 & NNW \\
\hline 26258 & PRCP & 1948 & 12 & -9 & & \\
\hline 26258 & MOVE & 1957 & 6 & -9 & 4 & SSW \\
\hline 26258 & MOVE & 1966 & 1 & -9 & 5 & E \\
\hline 26258 & MOVE & 1967 & 11 & -9 & 2 & NW \\
\hline 26258 & MOVE & 1986 & 6 & -9 & 4 & W \\
\hline 26406 & MOVE & 1922 & -9 & -9 & -9 & -99 \\
\hline 26406 & MOVE & 1927 & 10 & -9 & -9 & -99 \\
\hline 26406 & MOVE & 1945 & -9 & -9 & -9 & -99 \\
\hline 26406 & PRCP & 1953 & 1 & 1 & & \\
\hline 26406 & MOVE & 1961 & 7 & 5 & 5 & SSE \\
\hline 26422 & MOVE & 1872 & -9 & -9 & 0 & -99 \\
\hline 26422 & MOVE & 1876 & 5 & -9 & 0 & -99 \\
\hline 26422 & MOVE & 1923 & -9 & -9 & 0 & -99 \\
\hline 26422 & MOVE & 1941 & 5 & -9 & 0 & -99 \\
\hline 26422 & PRCP & 1957 & 11 & 1 & & \\
\hline 26477 & MOVE & 1921 & -9 & -9 & 0 & $S$ \\
\hline 26477 & MOVE & 1924 & 7 & -9 & 0 & -99 \\
\hline 26477 & MOVE & 1933 & 12 & -9 & 10 & NNE \\
\hline 26477 & MOVE & 1946 & 2 & -9 & 5 & NNE \\
\hline \multirow[t]{2}{*}{26477} & MOVE & 1946 & 9 & -9 & 2 & SSW \\
\hline & & & A-11 & & & \\
\hline
\end{tabular}




\begin{tabular}{|c|c|c|c|c|c|c|}
\hline WMO No. & Type & Year & Month & Day & Distance & Direction \\
\hline 26477 & PRCP & 1954 & 1 & -9 & & \\
\hline 26477 & MOVE & 1955 & 10 & -9 & 0 & NNE \\
\hline 26629 & MOVE & 1922 & -9 & -9 & 0 & -99 \\
\hline 26629 & PRCP & 1952 & 1 & 1 & & \\
\hline 26629 & MOVE & 1955 & 6 & 26 & 1 & $\mathbf{E}$ \\
\hline 26629 & MOVE & 1957 & 6 & 5 & 0 & $\mathbf{W}$ \\
\hline 26702 & MOVE & 1889 & 10 & -9 & 0 & -99 \\
\hline 26702 & MOVE & 1922 & 10 & 1 & 0 & -99 \\
\hline 26702 & MOVE & 1946 & 12 & -9 & 0 & -99 \\
\hline 26702 & PRCP & 1952 & 1 & 1 & & \\
\hline 26730 & MOVE & 1892 & 1 & 1 & 0 & $\mathbf{S}$ \\
\hline 26730 & MOVE & 1916 & 3 & 1 & 0 & -99 \\
\hline 26730 & MOVE & 1920 & 6 & 1 & 0 & SSW \\
\hline 26730 & MOVE & 1922 & 7 & 1 & 0 & $\mathbf{W}$ \\
\hline 26730 & MOVE & 1936 & 3 & 23 & 0 & W \\
\hline 26730 & PRCP & 1952 & 1 & 1 & & \\
\hline 26730 & MOVE & 1953 & 12 & 14 & 3 & $\mathrm{NE}$ \\
\hline 26730 & MOVE & 1964 & 6 & 1 & 0 & -99 \\
\hline 26781 & MOVE & 1900 & 2 & -9 & 0 & -99 \\
\hline 26781 & MOVE & 1905 & 9 & -9 & 0 & -99 \\
\hline 26781 & MOVE & 1911 & -9 & -9 & 0 & -99 \\
\hline 26781 & MOVE & 1936 & -9 & -9 & 0 & -99 \\
\hline 26781 & PRCP & 1951 & 10 & -9 & & \\
\hline 26850 & MOVE & 1870 & -9 & -9 & 0 & -99 \\
\hline 26850 & MOVE & 1891 & -9 & -9 & 0 & -99 \\
\hline 26850 & MOVE & 1895 & -9 & -9 & 0 & -99 \\
\hline 26850 & MOVE & 1905 & -9 & -9 & 0 & -99 \\
\hline 26850 & MOVE & 1922 & -9 & -9 & 0 & -99 \\
\hline 26850 & MOVE & 1935 & -9 & -9 & 0 & -99 \\
\hline 26850 & PRCP & 1948 & 6 & -9 & & \\
\hline 27037 & MOVE & 1945 & 10 & -9 & 0 & $\mathbf{E}$ \\
\hline 27037 & MOVE & 1951 & 10 & -9 & 10 & $\mathbf{N}$ \\
\hline 27037 & PRCP & 1954 & 4 & -9 & & \\
\hline 27037 & MOVE & 1959 & 9 & -9 & 2 & $\mathbf{S}$ \\
\hline 27037 & MOVE & 1968 & 4 & -9 & 0 & SW \\
\hline 27037 & MOVE & 1979 & 9 & -9 & 3 & $\mathbf{N}$ \\
\hline
\end{tabular}


WMO No.

\begin{tabular}{|c|c|c|c|c|c|c|}
\hline 27196 & MOVE & 1922 & 12 & 3 & 0 & $s$ \\
\hline 27196 & MOVE & 1936 & 11 & 17 & 1 & SW \\
\hline 27196 & PRCP & 1949 & 5 & -9 & & \\
\hline 27196 & MOVE & 1957 & 2 & 15 & 1 & SW \\
\hline 27333 & MOVE & 1883 & -9 & -9 & 0 & -99 \\
\hline 27333 & MOVE & 1913 & 3 & -9 & 0 & -99 \\
\hline 27333 & MOVE & 1920 & 7 & -9 & 3 & SE \\
\hline 27333 & MOVE & 1924 & 6 & -9 & 0 & -99 \\
\hline 27333 & MOVE & 1936 & 5 & -9 & 1 & W \\
\hline 27333 & PRCP & 1949 & 6 & 10 & & \\
\hline 27553 & MOVE & 1892 & 6 & -9 & 1 & SW \\
\hline 27553 & MOVE & 1904 & 12 & -9 & 2 & E \\
\hline 27553 & MOVE & 1922 & 5 & -9 & 2 & SE \\
\hline 27553 & MOVE & 1932 & 7 & -9 & 7 & SSW \\
\hline 27553 & PRCP & 1948 & 12 & 17 & & \\
\hline 27595 & MOVE & 1921 & -9 & -9 & 0 & -99 \\
\hline 27595 & PRCP & 1953 & 6 & -9 & & \\
\hline 27595 & MOVE & 1962 & 8 & 22 & 0 & $\mathrm{NE}$ \\
\hline 27595 & MOVE & 1988 & 8 & -9 & 0 & $S$ \\
\hline 27612 & MOVE & 1939 & 8 & 1 & 0 & -99 \\
\hline 27612 & PRCP & 1952 & -9 & -9 & & \\
\hline 27648 & MOVE & 1919 & -9 & -9 & 0 & $\mathrm{~N}$ \\
\hline 27648 & MOVE & 1932 & 9 & -9 & 1 & W \\
\hline 27648 & PRCP & 1950 & 7 & -9 & & \\
\hline 27823 & MOVE & 1930 & 11 & -9 & 1 & SE \\
\hline 27823 & MOVE & 1943 & 1 & -9 & 1 & W \\
\hline 27823 & PRCP & 1951 & 1 & 1 & & \\
\hline 27947 & MOVE & 1932 & 9 & 19 & 1 & -99 \\
\hline 27947 & PRCP & 1953 & 1 & 1 & & \\
\hline 27947 & MOVE & 1957 & 9 & 30 & 2 & -99 \\
\hline 28064 & MOVE & -999 & -9 & -9 & -9 & -99 \\
\hline 28064 & PRCP & 1953 & 1 & 10 & & \\
\hline 28138 & MOVE & -999 & -9 & -9 & -9 & -99 \\
\hline \multirow[t]{2}{*}{28138} & PRCP & 1956 & 5 & -9 & & \\
\hline & & & A-13 & & & \\
\hline
\end{tabular}


WMO No. Type Mear Month Day Distance Direction

\begin{tabular}{|c|c|c|c|c|c|c|}
\hline 28225 & MOVE & 1938 & 4 & -9 & 2 & -99 \\
\hline 28225 & PRCP & 1952 & -9 & -9 & & \\
\hline 28275 & MOVE & 1890 & 7 & -9 & 0 & -99 \\
\hline 28275 & MOVE & 1895 & 4 & -9 & 0 & $\mathbf{N}$ \\
\hline 28275 & MOVE & 1895 & 10 & -9 & 0 & $\mathbf{S}$ \\
\hline 28275 & PRCP & 1951 & 1 & -9 & & \\
\hline 28411 & MOVE & 1932 & 9 & -9 & -9 & -99 \\
\hline 28411 & MOVE & 1940 & 2 & -9 & 7 & SE \\
\hline 28411 & MOVE & 1940 & 12 & -9 & 7 & NW \\
\hline 28411 & MOVE & 1950 & 9 & 1 & 0 & $\mathrm{E}$ \\
\hline 28411 & PRCP & 1951 & 5 & 30 & & \\
\hline 28411 & MOVE & 1961 & 6 & 1 & 5 & $\mathrm{E}$ \\
\hline 28411 & MOVE & 1974 & 10 & -9 & 10 & $\mathrm{E}$ \\
\hline 28411 & MOVE & 1977 & 8 & -9 & 1 & NE \\
\hline 28434 & PRCP & 1949 & 9 & -9 & & \\
\hline 28434 & MOVE & 1956 & 11 & 5 & 6 & $\mathbf{N}$ \\
\hline 28434 & MOVE & 1963 & 9 & 6 & 0 & $\mathbf{S}$ \\
\hline 28434 & MOVE & 1973 & -9 & -9 & 0 & -99 \\
\hline 28440 & PRCP & 1948 & 3 & 1 & & \\
\hline 28440 & MOVE & 1969 & -9 & -9 & 1 & -99 \\
\hline 28493 & MOVE & 1925 & -9 & -9 & 0 & -99 \\
\hline 28493 & MOVE & 1936 & 8 & -9 & 3 & -99 \\
\hline 28493 & MOVE & 1951 & 10 & -9 & 5 & SW \\
\hline 28493 & PRCP & 1951 & 10 & -9 & & \\
\hline 28493 & MOVE & 1986 & -9 & -9 & 0 & -99 \\
\hline 28661 & MOVE & 1935 & -9 & -9 & 0 & -99 \\
\hline 28661 & MOVE & 1942 & 8 & -9 & 2 & NE \\
\hline 28661 & PRCP & 1954 & 10 & 28 & & \\
\hline 28661 & MOVE & 1975 & -9 & -9 & 2 & -99 \\
\hline 28679 & MOVE & 1935 & 12 & 31 & 6 & $\mathrm{NE}$ \\
\hline 28679 & MOVE & 1936 & 11 & 24 & 8 & SSW \\
\hline 28679 & PRCP & 1951 & 1 & -9 & & \\
\hline 28679 & MOVE & 1974 & 7 & 11 & 6 & $\mathbf{S}$ \\
\hline 28698 & MOVE & 1935 & -9 & -9 & 0 & W \\
\hline
\end{tabular}




\begin{tabular}{|c|c|c|c|c|c|c|}
\hline WMO No. & Type & Year & Month & Day & Distance & Direction \\
\hline 28698 & PRCP & 1952 & 1 & 1 & & \\
\hline 28722 & MOVE & 1942 & -9 & -9 & 0 & $\mathbf{S}$ \\
\hline 28722 & PRCP & 1954 & -9 & -9 & & \\
\hline 28722 & MOVE & 1957 & -9 & -9 & 0 & $\mathbf{N}$ \\
\hline 28900 & PRCP & 1949 & 8 & 31 & & \\
\hline 28900 & MOVE & 1973 & 6 & -9 & 0 & NNE \\
\hline 28952 & MOVE & 1933 & 4 & -9 & 7 & SE \\
\hline 28952 & PRCP & 1952 & 9 & 1 & & \\
\hline 28952 & MOVE & 1953 & 7 & 18 & 0 & SW \\
\hline 28952 & MOVE & 1957 & 6 & 28 & 0 & NE \\
\hline 29231 & MOVE & 1935 & 12 & 24 & 9 & W \\
\hline 29231 & MOVE & 1947 & 10 & 14 & 2 & $\mathbf{E}$ \\
\hline 29231 & PRCP & 1950 & 7 & 1 & & \\
\hline 29231 & MOVE & 1963 & 8 & -9 & 1 & $\mathbf{N}$ \\
\hline 29231 & MOVE & 1983 & 12 & -9 & 2 & $\mathbf{E}$ \\
\hline 29263 & MOVE & -999 & -9 & -9 & -9 & -99 \\
\hline 29263 & PRCP & 1955 & 8 & 22 & & \\
\hline 29282 & MOVE & 1935 & 8 & 6 & 0 & $\mathrm{~N}$ \\
\hline 29282 & PRCP & 1953 & 8 & 3 & & \\
\hline 29282 & MOVE & 1960 & 12 & 9 & 2 & NW \\
\hline 29430 & MOVE & 1883 & 7 & 29 & 0 & -99 \\
\hline 29430 & MOVE & 1897 & 8 & 21 & 0 & SE \\
\hline 29430 & MOVE & 1934 & 4 & 18 & 3 & -99 \\
\hline 29430 & PRCP & 1947 & 6 & 25 & & \\
\hline 29574 & MOVE & -999 & -9 & -9 & -9 & -99 \\
\hline 29574 & PRCP & 1951 & 6 & 15 & & \\
\hline 29612 & MOVE & 1939 & 5 & 21 & 2 & $\mathbf{N}$ \\
\hline 29612 & MOVE & 1949 & 10 & 20 & 4 & NW \\
\hline 29612 & PRCP & 1955 & 9 & 19 & & \\
\hline 29612 & MOVE & 1958 & 12 & 4 & 0 & NE \\
\hline 29698 & MOVE & 1905 & -9 & -9 & 0 & -99 \\
\hline 29698 & MOVE & 1911 & -9 & -9 & 0 & -99 \\
\hline 29698 & MOVE & 1915 & -9 & -9 & 0 & -99 \\
\hline
\end{tabular}




\begin{tabular}{|c|c|c|c|c|c|c|}
\hline WMO No. & Type & Year & Month & Day & Distance & Direction \\
\hline 29698 & MOVE & 1932 & 11 & 1 & 0 & -99 \\
\hline 29698 & MOVE & 1939 & 8 & 1 & 0 & -99 \\
\hline 29698 & MOVE & 1946 & 10 & 16 & 1 & $\mathbf{S}$ \\
\hline 29698 & PRCP & 1950 & 9 & 1 & & \\
\hline 29807 & MOVE & -999 & -9 & -9 & -9 & -99 \\
\hline 29807 & PRCP & 1951 & 7 & 1 & & \\
\hline 29838 & PRCP & 1951 & 6 & 25 & & \\
\hline 29838 & MOVE & 1970 & 9 & -9 & 1 & NW \\
\hline 29866 & MOVE & -999 & -9 & -9 & -9 & -99 \\
\hline 29866 & PRCP & 1951 & 8 & 6 & & \\
\hline 30054 & MOVE & -999 & -9 & -9 & -9 & -99 \\
\hline 30054 & PRCP & 1953 & 1 & 1 & & \\
\hline 30230 & MOVE & -999 & -9 & -9 & -9 & -99 \\
\hline 30230 & PRCP & 1950 & 1 & -9 & & \\
\hline 30253 & MOVE & 1933 & 10 & 12 & 0 & $\mathrm{E}$ \\
\hline 30253 & MOVE & 1942 & 8 & 29 & 0 & $\mathrm{E}$ \\
\hline 30253 & MOVE & 1947 & 10 & 4 & 2 & $\mathrm{NE}$ \\
\hline 30253 & PRCP & 1950 & 4 & -9 & & \\
\hline 30372 & MOVE & 1949 & 10 & -9 & 1 & $\mathrm{NE}$ \\
\hline 30372 & PRCP & 1957 & 6 & -9 & & \\
\hline 30393 & MOVE & 1940 & 9 & 12 & 1 & $S$ \\
\hline 30393 & PRCP & 1953 & 2 & 1 & & \\
\hline 30393 & MOVE & 1966 & 1 & 1 & 6 & $\mathbf{N}$ \\
\hline 30393 & MOVE & 1988 & 7 & -9 & 2 & NE \\
\hline 30521 & MOVE & 1946 & 10 & 16 & 1 & $S$ \\
\hline 30521 & PRCP & 1951 & 10 & -9 & & \\
\hline 30521 & MOVE & 1967 & 9 & -9 & 3 & $\mathrm{E}$ \\
\hline 30555 & PRCP & 1956 & 9 & -9 & & \\
\hline 30555 & MOVE & 1969 & 2 & -9 & 0 & $\mathbf{S}$ \\
\hline 30636 & MOVE & 1931 & 7 & -9 & -9 & $\mathbf{N}$ \\
\hline 30636 & MOVE & 1933 & 10 & -9 & -9 & $S$ \\
\hline 30636 & MOVE & 1936 & 3 & -9 & 1 & NE \\
\hline
\end{tabular}




\begin{tabular}{|c|c|c|c|c|c|c|}
\hline WMO No. & Type & Year & Month & Day & Distance & Direction \\
\hline 30636 & MOVE & 1952 & -9 & -9 & 2 & W \\
\hline 30636 & PRCP & 1954 & 6 & -9 & & \\
\hline 30636 & MOVE & 1963 & 11 & -9 & 0 & SSE \\
\hline 30673 & MOVE & 1934 & -9 & -9 & 0 & SSW \\
\hline 30673 & MOVE & 1937 & -9 & -9 & 1 & NW \\
\hline 30673 & PRCP & 1950 & 5 & -9 & & \\
\hline 30673 & MOVE & 1956 & 10 & -9 & 0 & NE \\
\hline 30692 & MOVE & 1932 & 10 & -9 & 3 & NE \\
\hline 30692 & MOVE & 1933 & -9 & -9 & 0 & $S$ \\
\hline 30692 & MOVE & 1937 & 6 & -9 & 0 & $\mathbf{S}$ \\
\hline 30692 & PRCP & 1953 & 9 & 10 & & \\
\hline 30710 & MOVE & -999 & -9 & -9 & -9 & -99 \\
\hline 30710 & PRCP & 1950 & 1 & -9 & & \\
\hline 30758 & MOVE & 1913 & 6 & -9 & 0 & -99 \\
\hline 30758 & MOVE & 1915 & 10 & -9 & 0 & -99 \\
\hline 30758 & MOVE & 1931 & 10 & -9 & 0 & -99 \\
\hline 30758 & PRCP & 1948 & 10 & -9 & & \\
\hline 30758 & MOVE & 1955 & 3 & 24 & 0 & $\mathbf{N}$ \\
\hline 30777 & MOVE & 1911 & 9 & -9 & -9 & -99 \\
\hline 30777 & MOVE & 1942 & 6 & -9 & 3 & SSW \\
\hline 30777 & MOVE & 1945 & 7 & -9 & 0 & $\mathrm{NE}$ \\
\hline 30777 & PRCP & 1949 & 7 & -9 & & \\
\hline 30777 & MOVE & 1956 & 4 & -9 & 1 & SE \\
\hline 30823 & MOVE & 1901 & 8 & -9 & 1 & NE \\
\hline 30823 & MOVE & 1919 & 4 & -9 & 4 & SE \\
\hline 30823 & MOVE & 1934 & 11 & -9 & 3 & NE \\
\hline 30823 & MOVE & 1942 & 7 & -9 & 12 & WSW \\
\hline 30823 & MOVE & 1947 & -9 & -9 & 12 & ENE \\
\hline 30823 & PRCP & 1949 & 11 & -9 & & \\
\hline 30823 & MOVE & 1953 & -9 & -9 & 2 & SW \\
\hline 30925 & MOVE & 1933 & 1 & -9 & -9 & NE \\
\hline 30925 & PRCP & 1954 & 9 & -9 & & \\
\hline 30949 & PRCP & 1951 & 12 & 11 & & \\
\hline 30949 & MOVE & 1956 & 7 & -9 & 0 & $\mathbf{N}$ \\
\hline
\end{tabular}




\begin{tabular}{|c|c|c|c|c|c|c|}
\hline WMO No. & Type & Year & Month & Day & Distance & Direction \\
\hline 30965 & PRCP & 1952 & 4 & -9 & & \\
\hline 30965 & MOVE & 1953 & 5 & -9 & 1 & NNE \\
\hline 31004 & MOVE & 1931 & 10 & -9 & 1 & -99 \\
\hline 31004 & MOVE & 1941 & 12 & -9 & 0 & NE \\
\hline 31004 & PRCP & 1948 & 9 & -9 & & \\
\hline 31004 & MOVE & 1952 & 7 & -9 & 0 & $\mathbf{S}$ \\
\hline 31004 & MOVE & 1970 & 8 & 11 & 0 & NW \\
\hline 31088 & PRCP & 1952 & -9 & -9 & & \\
\hline 31088 & MOVE & 1969 & 10 & 7 & 1 & NNE \\
\hline 31168 & MOVE & -999 & -9 & -9 & -9 & -99 \\
\hline 31168 & PRCP & 1950 & 9 & 24 & & \\
\hline 31253 & MOVE & -999 & -9 & -9 & -9 & -99 \\
\hline 31253 & PRCP & 1951 & 7 & 1 & & \\
\hline 31329 & MOVE & 1952 & 1 & -9 & 0 & -99 \\
\hline 31329 & PRCP & 1955 & 9 & 20 & & \\
\hline 31369 & MOVE & 1909 & 10 & -9 & 1 & $\mathbf{N}$ \\
\hline 31369 & MOVE & 1925 & 8 & 22 & 0 & $\mathbf{N}$ \\
\hline 31369 & MOVE & 1932 & 10 & 20 & 0 & SE \\
\hline 31369 & MOVE & 1949 & 6 & 17 & 3 & $\mathbf{W}$ \\
\hline 31369 & PRCP & 1953 & 10 & -9 & & \\
\hline 31388 & MOVE & 1925 & -9 & -9 & 5 & -99 \\
\hline 31388 & MOVE & 1932 & 9 & -9 & 1 & $\mathbf{S}$ \\
\hline 31388 & PRCP & 1953 & 11 & -9 & & \\
\hline 31416 & MOVE & 1914 & -9 & -9 & 0 & -99 \\
\hline 31416 & MOVE & 1939 & 10 & -9 & 0 & -99 \\
\hline 31416 & PRCP & 1954 & 1 & 28 & & \\
\hline 31416 & MOVE & 1960 & 9 & -9 & 1 & $\mathbf{N}$ \\
\hline 31510 & MOVE & 1880 & 11 & -9 & 0 & -99 \\
\hline 31510 & MOVE & 1898 & 9 & -9 & 0 & -99 \\
\hline 31510 & MOVE & 1910 & -9 & -9 & 0 & -99 \\
\hline 31510 & MOVE & 1912 & 10 & -9 & 0 & -99 \\
\hline 31510 & MOVE & 1943 & 10 & 11 & 0 & -99 \\
\hline 31510 & PRCP & 1953 & 1 & 31 & & \\
\hline
\end{tabular}




\begin{tabular}{|c|c|c|c|c|c|c|}
\hline WMO No. & Type & Year & Month & Day & Distance & Direction \\
\hline 31532 & PRCP & 1954 & 6 & 8 & & \\
\hline 31532 & MOVE & 1979 & 6 & -9 & 10 & NE \\
\hline 31594 & MOVE & 1932 & 11 & -9 & 0 & $\mathbf{S}$ \\
\hline 31594 & MOVE & 1933 & 4 & -9 & 0 & $\mathbf{N}$ \\
\hline 31594 & MOVE & 1935 & -9 & -9 & 0 & $\mathbf{S}$ \\
\hline 31594 & PRCP & 1953 & 12 & 26 & & \\
\hline 31707 & MOVE & 1912 & -9 & -9 & 1 & $\mathbf{E}$ \\
\hline 31707 & MOVE & 1925 & -9 & -9 & 1 & $\mathbf{E}$ \\
\hline 31707 & MOVE & 1931 & 6 & -9 & 10 & -99 \\
\hline 31707 & MOVE & 1934 & 8 & 10 & 10 & -99 \\
\hline 31707 & PRCP & 1954 & 8 & 18 & & \\
\hline 31707 & MOVE & 1959 & 10 & -9 & 1 & SE \\
\hline 31735 & MOVE & 1890 & -9 & -9 & 0 & -99 \\
\hline 31735 & MOVE & 1910 & -9 & -9 & 0 & -99 \\
\hline 31735 & MOVE & 1914 & -9 & -9 & 0 & -99 \\
\hline 31735 & MOVE & 1927 & 8 & -9 & 0 & -99 \\
\hline 31735 & MOVE & 1932 & -9 & -9 & 0 & -99 \\
\hline 31735 & MOVE & 1942 & -9 & -9 & 0 & -99 \\
\hline 31735 & MOVE & 1946 & -9 & -9 & 0 & -99 \\
\hline 31735 & PRCP & 1950 & 11 & 25 & & \\
\hline 31735 & MOVE & 1968 & -9 & -9 & 0 & -99 \\
\hline 31829 & MOVE & -999 & -9 & -9 & -9 & -99 \\
\hline 31829 & PRCP & 1950 & 8 & -9 & & \\
\hline 31873 & PRCP & 1953 & 5 & -9 & & \\
\hline 31873 & MOVE & 1960 & 10 & -9 & 0 & SE \\
\hline 31909 & PRCP & 1950 & 5 & -9 & & \\
\hline 31909 & MOVE & 1975 & 6 & -9 & 2 & NW \\
\hline 31915 & PRCP & 1953 & 4 & -9 & & \\
\hline 31915 & MOVE & 1953 & 4 & 27 & 1 & SW \\
\hline 31960 & MOVE & -999 & -9 & -9 & -9 & -99 \\
\hline 31960 & PRCP & 1949 & 7 & -9 & & \\
\hline 32061 & MOVE & 1899 & 1 & -9 & 0 & $\mathbf{N}$ \\
\hline 32061 & PRCP & 1950 & 5 & 20 & & \\
\hline 32061 & MOVE & 1960 & 12 & 1 & 3 & $\mathbf{N}$ \\
\hline
\end{tabular}


WMO No. Type

Year Month Day Distance Direction

\begin{tabular}{|c|c|c|c|c|c|c|}
\hline 32098 & PRCP & 1949 & 5 & 27 & & \\
\hline 32098 & MOVE & 1977 & 1 & 1 & 0 & -99 \\
\hline 32165 & PRCP & 1950 & 6 & -9 & & \\
\hline 32165 & MOVE & 1957 & 1 & 1 & 5 & $\mathrm{E}$ \\
\hline 32165 & MOVE & 1980 & -9 & -9 & 0 & -99 \\
\hline 32389 & PRCP & 1951 & 1 & 1 & & \\
\hline 32389 & MOVE & 1956 & 7 & 15 & 0 & E \\
\hline 32411 & MOVE & -999 & -9 & -9 & -9 & -99 \\
\hline 32411 & PRCP & 1953 & 10 & 23 & & \\
\hline 32540 & MOVE & 1909 & 7 & -9 & 0 & NNW \\
\hline 32540 & MOVE & 1938 & -9 & -9 & 0 & NW \\
\hline 32540 & PRCP & 1951 & 1 & 1 & & \\
\hline 32564 & MOVE & 1914 & -9 & -9 & 0 & -99 \\
\hline 32564 & PRCP & 1952 & 10 & 29 & & \\
\hline 33008 & MOVE & 1905 & 8 & -9 & 0 & -99 \\
\hline 33008 & MOVE & 1912 & 5 & -9 & 1 & -99 \\
\hline 33008 & MOVE & 1914 & -9 & -9 & 0 & -99 \\
\hline 33008 & MOVE & 1944 & 10 & -9 & 0 & -99 \\
\hline 33008 & MOVE & 1945 & 10 & 8 & 2 & WSW \\
\hline 33008 & MOVE & 1947 & 10 & 1 & 2 & ENE \\
\hline 33008 & PRCP & 1949 & 6 & -9 & & \\
\hline 33008 & MOVE & 1960 & 10 & 4 & 1 & $\mathbf{N}$ \\
\hline 33038 & MOVE & 1923 & -9 & -9 & 1 & E \\
\hline 33038 & MOVE & 1942 & 9 & -9 & 0 & -99 \\
\hline 33038 & MOVE & 1945 & 4 & -9 & 1 & SSE \\
\hline 33038 & PRCP & 1949 & 9 & 28 & & \\
\hline 33038 & MOVE & 1987 & -9 & -9 & 0 & -99 \\
\hline 33345 & PRCP & 1948 & -9 & -9 & & \\
\hline 33345 & MOVE & 1982 & -9 & -9 & 6 & E \\
\hline 33377 & MOVE & 1920 & 7 & -9 & 1 & -99 \\
\hline 33377 & MOVE & 1928 & 11 & 1 & 2 & SE \\
\hline 33377 & MOVE & 1943 & 9 & 22 & 2 & NW \\
\hline 33377 & MOVE & 1951 & 10 & -9 & 0 & WNW \\
\hline
\end{tabular}




\begin{tabular}{|c|c|c|c|c|c|c|}
\hline WMO No. & Type & Year & Month & Day & Distance & Direction \\
\hline 33377 & PRCP & 1953 & 1 & 1 & & \\
\hline 33393 & MOVE & 1900 & -9 & -9 & 0 & -99 \\
\hline 33393 & MOVE & 1940 & 5 & -9 & 0 & -99 \\
\hline 33393 & PRCP & 1952 & 4 & 17 & & \\
\hline 33393 & MOVE & 1962 & -9 & -9 & 1 & SE \\
\hline 33562 & MOVE & 1922 & 5 & -9 & 1 & $\mathrm{NE}$ \\
\hline 33562 & MOVE & 1927 & 1 & 1 & 5 & WSW \\
\hline 33562 & MOVE & 1940 & 1 & 28 & 4 & $\mathrm{NE}$ \\
\hline 33562 & PRCP & 1950 & 9 & 27 & & \\
\hline 33562 & MOVE & 1964 & 4 & 10 & 9 & $\mathbf{E}$ \\
\hline 33562 & MOVE & 1983 & -9 & -9 & 4 & $\mathbf{N}$ \\
\hline 33631 & MOVE & -999 & -9 & -9 & -9 & -99 \\
\hline 33631 & PRCP & 1952 & 10 & -9 & & \\
\hline 33658 & MOVE & -999 & -9 & -9 & -9 & -99 \\
\hline 33658 & PRCP & 1954 & 3 & 1 & & \\
\hline 33815 & MOVE & 1940 & -9 & -9 & 2 & SE \\
\hline 33815 & PRCP & 1952 & 1 & 3 & & \\
\hline 33815 & MOVE & 1975 & -9 & -9 & 0 & -99 \\
\hline 33837 & MOVE & 1924 & -9 & -9 & 1 & -99 \\
\hline 33837 & PRCP & 1947 & -9 & -9 & & \\
\hline 33889 & PRCP & 1953 & 1 & 1 & & \\
\hline 33889 & MOVE & 1959 & 1 & -9 & 2 & $\mathrm{SE}$ \\
\hline 33889 & MOVE & 1960 & 12 & 23 & 6 & NNE \\
\hline 33910 & MOVE & 1910 & -9 & -9 & 0 & -99 \\
\hline 33910 & MOVE & 1936 & 2 & 1 & 1 & -99 \\
\hline 33910 & MOVE & 1943 & 12 & -9 & 0 & -99 \\
\hline 33910 & PRCP & 1953 & 2 & 1 & & \\
\hline 33915 & MOVE & 1925 & 3 & 17 & 1 & $S$ \\
\hline 33915 & PRCP & 1949 & 10 & 15 & & \\
\hline 33915 & MOVE & 1964 & 12 & 12 & 0 & SE \\
\hline 33946 & MOVE & -999 & -9 & -9 & -9 & -99 \\
\hline 33946 & PRCP & 1949 & -9 & -9 & & \\
\hline
\end{tabular}




\begin{tabular}{|c|c|c|c|c|c|c|}
\hline WMO No. & Type & Year & Month & Day & Distance & Direction \\
\hline 33976 & MOVE & 1944 & 5 & -9 & 1 & NNW \\
\hline 33976 & PRCP & 1953 & 2 & -9 & & \\
\hline 33983 & MOVE & 1948 & 6 & 25 & 0 & -99 \\
\hline 33983 & MOVE & 1949 & 11 & 30 & 7 & SW \\
\hline 33983 & PRCP & 1953 & 1 & 1 & & \\
\hline 33983 & MOVE & 1958 & 5 & 13 & 0 & $\mathbf{E}$ \\
\hline 33983 & MOVE & 1960 & 10 & 17 & 0 & $\mathbf{N}$ \\
\hline 33983 & MOVE & 1973 & 10 & 31 & 3 & $\mathbf{N}$ \\
\hline 34009 & PRCP & 1953 & 1 & 1 & & \\
\hline 34009 & MOVE & 1957 & 7 & 1 & 4 & -99 \\
\hline 34122 & MOVE & 1930 & 5 & 29 & 1 & -99 \\
\hline 34122 & PRCP & 1953 & 1 & 1 & & \\
\hline 34139 & MOVE & -999 & -9 & -9 & -9 & -99 \\
\hline 34139 & PRCP & 1953 & 1 & 1 & & \\
\hline 34163 & MOVE & 1931 & -9 & -9 & -9 & -99 \\
\hline 34163 & MOVE & 1934 & 7 & 26 & -9 & NW \\
\hline 34163 & PRCP & 1954 & 4 & 18 & & \\
\hline 34163 & MOVE & 1960 & 9 & 21 & 0 & NW \\
\hline 34172 & MOVE & 1922 & 5 & -9 & 1 & $S$ \\
\hline 34172 & MOVE & 1952 & 11 & -9 & 1 & NE \\
\hline 34172 & PRCP & 1953 & 7 & -9 & 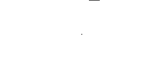 & \\
\hline 34300 & MOVE & 1933 & -9 & -9 & 0 & -99 \\
\hline 34300 & MOVE & 1938 & 7 & -9 & 0 & NE \\
\hline 34300 & MOVE & 1940 & -9 & -9 & 0 & $\mathbf{N}$ \\
\hline 34300 & PRCP & 1951 & -9 & -9 & & \\
\hline 34391 & PRCP & 1953 & 10 & -9 & & \\
\hline 34391 & MOVE & 1953 & 10 & 15 & 0 & $\mathbf{S}$ \\
\hline 34391 & MOVE & 1967 & 9 & -9 & 0 & $\mathbf{N}$ \\
\hline 34524 & MOVE & 1929 & 11 & 24 & 1 & SE \\
\hline 34524 & MOVE & 1934 & 12 & 13 & 4 & NE \\
\hline 34524 & PRCP & 1951 & -9 & -9 & & \\
\hline 34646 & MOVE & 1933 & 10 & 6 & 1 & $\mathbf{N}$ \\
\hline 34646 & MOVE & 1946 & 4 & 20 & 1 & $\mathbf{N}$ \\
\hline
\end{tabular}




\begin{tabular}{|c|c|c|c|c|c|c|}
\hline WMO No. & Type & Year & Month & Day & Distance & Direction \\
\hline 34646 & MOVE & 1951 & 11 & 14 & 2 & SW \\
\hline 34646 & PRCP & 1955 & 4 & -9 & & \\
\hline 34731 & MOVE & -999 & -9 & -9 & -9 & -99 \\
\hline 34731 & PRCP & 1951 & 2 & 1 & & \\
\hline 34747 & PRCP & 1947 & 8 & 10 & & \\
\hline 34747 & MOVE & 1978 & 8 & -9 & 0 & W \\
\hline 34824 & MOVE & -999 & -9 & -9 & -9 & -99 \\
\hline 34824 & PRCP & 1953 & 11 & -9 & & \\
\hline 34861 & MOVE & 1944 & 4 & 19 & 5 & ESE \\
\hline 34861 & PRCP & 1954 & 12 & -9 & & \\
\hline 34880 & PRCP & 1953 & 5 & 13 & & \\
\hline 34880 & MOVE & 1962 & 2 & 1 & 10 & -99 \\
\hline 35078 & MOVE & 1910 & 10 & -9 & 1 & $\mathbf{N}$ \\
\hline 35078 & MOVE & 1925 & -9 & -9 & 0 & -99 \\
\hline 35078 & MOVE & 1936 & 8 & 28 & 3 & $\mathbf{N}$ \\
\hline 35078 & PRCP & 1949 & 6 & 25 & & \\
\hline 35108 & MOVE & 1940 & 5 & -9 & 0 & -99 \\
\hline 35108 & PRCP & 1951 & -9 & -9 & & \\
\hline 35108 & MOVE & 1962 & 8 & 1 & 0 & -99 \\
\hline 35121 & MOVE & 1846 & -9 & -9 & 0 & -99 \\
\hline 35121 & MOVE & 1859 & -9 & -9 & 0 & -99 \\
\hline 35121 & MOVE & 1863 & -9 & -9 & 0 & -99 \\
\hline 35121 & MOVE & 1914 & 9 & -9 & 0 & -99 \\
\hline 35121 & PRCP & 1948 & 4 & 24 & & \\
\hline 35121 & MOVE & 1962 & 1 & -9 & 1 & $\mathrm{NE}$ \\
\hline 35121 & MOVE & 1975 & 1 & -9 & 12 & ENE \\
\hline 35133 & MOVE & 1935 & 9 & 28 & 1 & $\mathrm{NE}$ \\
\hline 35133 & PRCP & 1949 & 12 & 1 & & \\
\hline 35188 & MOVE & -999 & -9 & -9 & -9 & -99 \\
\hline 35188 & PRCP & 1951 & 1 & 1 & & \\
\hline 35229 & MOVE & 1937 & 8 & 5 & 0 & -99 \\
\hline 35229 & PRCP & 1953 & 5 & -9 & & \\
\hline
\end{tabular}




\begin{tabular}{|c|c|c|c|c|c|c|}
\hline WMO No. & Type & Year & Month & Day & Distance & Direction \\
\hline 35358 & MOVE & 1951 & -9 & -9 & 0 & -99 \\
\hline 35358 & PRCP & 1952 & 5 & -9 & & \\
\hline 35394 & MOVE & 1941 & 9 & 11 & 3 & NNE \\
\hline 35394 & MOVE & 1944 & 8 & 16 & 13 & $\mathbf{S}$ \\
\hline 35394 & PRCP & 1959 & 1 & 1 & & \\
\hline 35406 & MOVE & 1934 & 12 & 5 & 1 & SW \\
\hline 35406 & PRCP & 1949 & 4 & 17 & & \\
\hline 35406 & MOVE & 1951 & 12 & 20 & 1 & $\mathbf{S}$ \\
\hline 35416 & MOVE & -999 & -9 & -9 & -9 & -99 \\
\hline 35416 & PRCP & 1953 & 8 & 8 & & \\
\hline 35542 & MOVE & 1914 & 7 & -9 & 0 & -99 \\
\hline 35542 & MOVE & 1922 & 8 & 13 & 0 & -99 \\
\hline 35542 & MOVE & 1932 & 3 & -9 & 0 & $S$ \\
\hline 35542 & MOVE & 1939 & 7 & -9 & 0 & NW \\
\hline 35542 & PRCP & 1954 & 10 & -9 & & \\
\hline 35542 & MOVE & 1959 & 11 & -9 & 0 & -99 \\
\hline 35576 & MOVE & -999 & -9 & -9 & -9 & -99 \\
\hline 35576 & PRCP & 1953 & 3 & 19 & & \\
\hline 35663 & PRCP & 1960 & 9 & 8 & & \\
\hline 35663 & MOVE & 1962 & 8 & 12 & 1 & $\mathbf{S}$ \\
\hline 35700 & MOVE & 1937 & 5 & 20 & 2 & -99 \\
\hline 35700 & PRCP & 1953 & 5 & 26 & & \\
\hline 35746 & MOVE & 1925 & 11 & -9 & 0 & $\mathbf{S}$ \\
\hline 35746 & MOVE & 1931 & -9 & -9 & 0 & -99 \\
\hline 35746 & MOVE & 1942 & 12 & 15 & 0 & WSW \\
\hline 35746 & PRCP & 1953 & 1 & 31 & & \\
\hline 35746 & MOVE & 1953 & 11 & 30 & 6 & SW \\
\hline 35796 & MOVE & 1937 & 6 & -9 & 8 & SSW \\
\hline 35796 & MOVE & 1941 & 8 & -9 & 8 & NNE \\
\hline 35796 & PRCP & 1952 & 9 & 24 & & \\
\hline 36034 & MOVE & 1928 & 3 & 1 & 0 & W \\
\hline 36034 & MOVE & 1942 & 11 & 5 & 2 & W \\
\hline
\end{tabular}




\begin{tabular}{|c|c|c|c|c|c|c|}
\hline WMO No. & Type & Year & Month & Day & Distance & Direction \\
\hline 36034 & MOVE & 1943 & 5 & 6 & 2 & SE \\
\hline 36034 & PRCP & 1954 & -9 & -9 & & \\
\hline 36034 & MOVE & 1955 & 10 & 11 & 9 & NNW \\
\hline 36177 & MOVE & 1957 & 5 & 17 & 0 & -99 \\
\hline 36177 & PRCP & 1957 & 5 & 17 & & \\
\hline 36665 & MOVE & 1941 & 6 & 1 & 2 & NW \\
\hline 36665 & PRCP & 1950 & 10 & 1 & & \\
\hline 36729 & MOVE & 1938 & 9 & 14 & 0 & NNE \\
\hline 36729 & PRCP & 1952 & 2 & 20 & & \\
\hline 36729 & MOVE & 1955 & 7 & 27 & 2 & SE \\
\hline 36729 & MOVE & 1957 & 12 & -9 & 0 & -99 \\
\hline 36859 & MOVE & 1935 & 8 & 15 & 5 & ENE \\
\hline 36859 & MOVE & 1936 & 6 & 9 & 0 & SSE \\
\hline 36859 & PRCP & 1953 & 7 & 16 & & \\
\hline 36870 & MOVE & 1908 & 10 & -9 & 0 & -99 \\
\hline 36870 & MOVE & 1915 & -9 & -9 & 2 & NW \\
\hline 36870 & PRCP & 1951 & 6 & -9 & & \\
\hline 36974 & MOVE & 1935 & -9 & -9 & 0 & -99 \\
\hline 36974 & PRCP & 1949 & 5 & -9 & & \\
\hline 36974 & MOVE & 1960 & 12 & -9 & 1 & W \\
\hline 37031 & MOVE & 1933 & 9 & 5 & 1 & SW \\
\hline 37031 & PRCP & 1955 & 1 & 12 & & \\
\hline 37031 & MOVE & 1963 & 9 & 13 & 6 & $\mathbf{N}$ \\
\hline 37050 & PRCP & 1954 & 10 & 6 & & \\
\hline 37050 & MOVE & 1970 & -9 & -9 & 0 & -99 \\
\hline 37099 & MOVE & -999 & -9 & -9 & -9 & -99 \\
\hline 37099 & PRCP & 1958 & 6 & 1 & & \\
\hline 37235 & MOVE & 1917 & -9 & -9 & 0 & -99 \\
\hline 37235 & MOVE & 1925 & -9 & -9 & 0 & -99 \\
\hline 37235 & MOVE & 1937 & 6 & -9 & 0 & -99 \\
\hline 37235 & PRCP & 1954 & 12 & 10 & & \\
\hline 37235 & MOVE & 1980 & -9 & -9 & 0 & -99 \\
\hline
\end{tabular}




\begin{tabular}{|c|c|c|c|c|c|c|}
\hline WMO No. & Type & Year & Month & Day & Distance & Direction \\
\hline 37385 & MOVE & 1941 & 9 & -9 & 2 & $\mathbf{N}$ \\
\hline 37385 & PRCP & 1949 & -9 & -9 & & \\
\hline 37385 & MOVE & 1961 & 12 & 25 & 5 & SE \\
\hline 37472 & MOVE & 1897 & 6 & 1 & 2 & -99 \\
\hline 37472 & MOVE & 1921 & 5 & -9 & 0 & -99 \\
\hline 37472 & PRCP & 1949 & -9 & -9 & & \\
\hline 37472 & MOVE & 1983 & -9 & -9 & 0 & -99 \\
\hline 37549 & MOVE & 1851 & -9 & -9 & 1 & -99 \\
\hline 37549 & MOVE & 1861 & -9 & -9 & 0 & -99 \\
\hline 37549 & PRCP & 1947 & 7 & -9 & & \\
\hline 37549 & MOVE & 1965 & 5 & 1 & 3 & -99 \\
\hline 37686 & MOVE & 1934 & 4 & -9 & 3 & SE \\
\hline 37686 & MOVE & 1941 & 6 & 12 & 1 & NW \\
\hline 37686 & MOVE & 1952 & 10 & 2 & 3 & $\mathbf{N}$ \\
\hline 37686 & PRCP & 1953 & 1 & 5 & & \\
\hline 37686 & MOVE & 1961 & 4 & -9 & -9 & -99 \\
\hline 37735 & MOVE & 1924 & -9 & -9 & 0 & -99 \\
\hline 37735 & MOVE & 1925 & -9 & -9 & 0 & -99 \\
\hline 37735 & MOVE & 1926 & -9 & -9 & 0 & -99 \\
\hline 37735 & MOVE & 1940 & 6 & 6 & 0 & ENE \\
\hline 37735 & PRCP & 1948 & -9 & -9 & & \\
\hline 37735 & MOVE & 1951 & 4 & 7 & 0 & -99 \\
\hline 37735 & MOVE & 1958 & 3 & 20 & 1 & SSW \\
\hline 37789 & MOVE & 1934 & 4 & -9 & 0 & -99 \\
\hline 37789 & PRCP & 1950 & 5 & -9 & & \\
\hline 37789 & MOVE & 1974 & 12 & 25 & 2 & SSW \\
\hline 38198 & MOVE & 1930 & 11 & 26 & 5 & $\mathbf{W}$ \\
\hline 38198 & MOVE & 1938 & 8 & 23 & 2 & W \\
\hline 38198 & PRCP & 1955 & 3 & -9 & & \\
\hline 38262 & MOVE & 1940 & 10 & 1 & 4 & $\mathbf{N}$ \\
\hline 38262 & MOVE & 1950 & 4 & 12 & 5 & NW \\
\hline 38262 & MOVE & 1955 & 10 & 14 & 3 & $\mathrm{E}$ \\
\hline 38262 & PRCP & 1956 & 8 & 15 & & \\
\hline 38353 & MOVE & 1927 & 9 & -9 & 0 & -99 \\
\hline 38353 & MOVE & 1939 & 12 & -9 & 2 & $\mathbf{N}$ \\
\hline
\end{tabular}




\begin{tabular}{|c|c|c|c|c|c|c|}
\hline WMO No. & Type & Year & Month & Day & Distance & Direction \\
\hline 38353 & MOVE & 1940 & -9 & -9 & 1 & $\mathbf{E}$ \\
\hline 38353 & PRCP & 1949 & 5 & -9 & & \\
\hline 38413 & MOVE & 1936 & 8 & -9 & 2 & $\mathbf{E}$ \\
\hline 38413 & PRCP & 1950 & 3 & 6 & & \\
\hline 38413 & MOVE & 1957 & 12 & 19 & 3 & W \\
\hline 38457 & MOVE & -999 & -9 & -9 & -9 & -99 \\
\hline 38457 & PRCP & 1953 & -9 & -9 & & \\
\hline 38507 & MOVE & 1883 & -9 & -9 & 0 & -99 \\
\hline 38507 & MOVE & 1904 & -9 & -9 & 0 & -99 \\
\hline 38507 & MOVE & 1915 & 8 & -9 & 0 & -99 \\
\hline 38507 & MOVE & 1925 & 1 & -9 & 0 & -99 \\
\hline 38507 & PRCP & 1953 & 6 & 1 & & \\
\hline 38599 & MOVE & 1929 & 8 & -9 & 1 & $\mathbf{N}$ \\
\hline 38599 & MOVE & 1940 & 8 & 11 & 15 & $\mathbf{S}$ \\
\hline 38599 & PRCP & 1949 & 12 & 15 & & \\
\hline 38599 & MOVE & 1961 & 4 & -9 & 1 & $\mathbf{S}$ \\
\hline 38599 & MOVE & 1966 & 10 & 15 & 2 & WSW \\
\hline 38618 & MOVE & 1881 & -9 & -9 & 0 & -99 \\
\hline 38618 & MOVE & 1889 & -9 & -9 & 0 & -99 \\
\hline 38618 & MOVE & 1921 & 10 & -9 & 0 & -99 \\
\hline 38618 & MOVE & 1928 & 7 & 19 & 3 & SE \\
\hline 38618 & MOVE & 1933 & 1 & -9 & 2 & W \\
\hline 38618 & PRCP & 1951 & 12 & 31 & & \\
\hline 38687 & MOVE & 1913 & 10 & 11 & 0 & -99 \\
\hline 38687 & PRCP & 1952 & 8 & 2 & & \\
\hline 38696 & MOVE & -999 & -9 & -9 & -9 & -99 \\
\hline 38696 & PRCP & 1951 & 1 & 1 & & \\
\hline 38750 & MOVE & -999 & -9 & -9 & -9 & -99 \\
\hline 38750 & PRCP & 1953 & 9 & 1 & & \\
\hline 38763 & MOVE & 1908 & 3 & 12 & 0 & -99 \\
\hline 38763 & MOVE & 1925 & -9 & -9 & 0 & -99 \\
\hline 38763 & PRCP & 1953 & 1 & 1 & & \\
\hline 38763 & MOVE & 1958 & 1 & -9 & 2 & W \\
\hline
\end{tabular}


APPENDIX B

REPRINT OF PERTINENT LITERATURE 


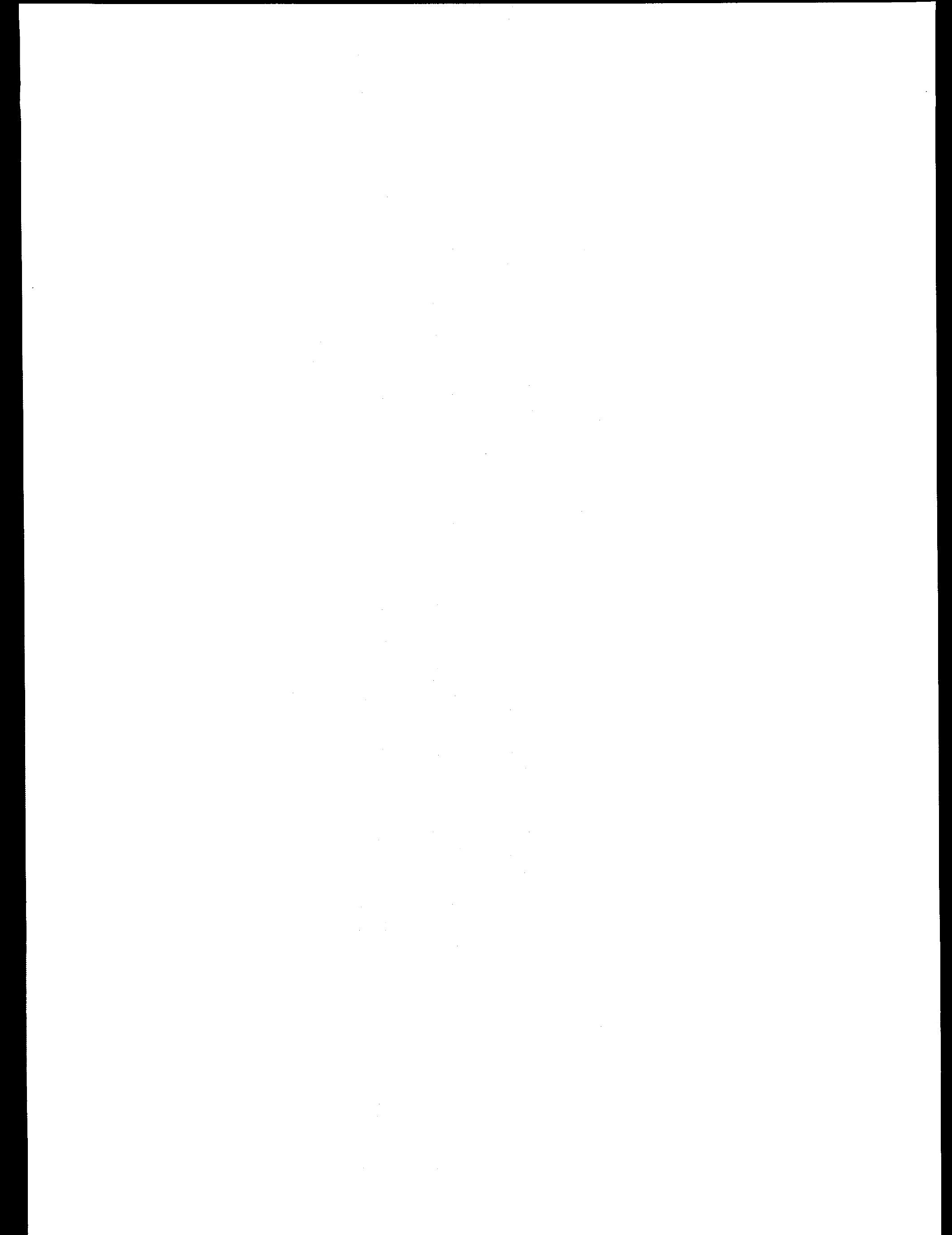




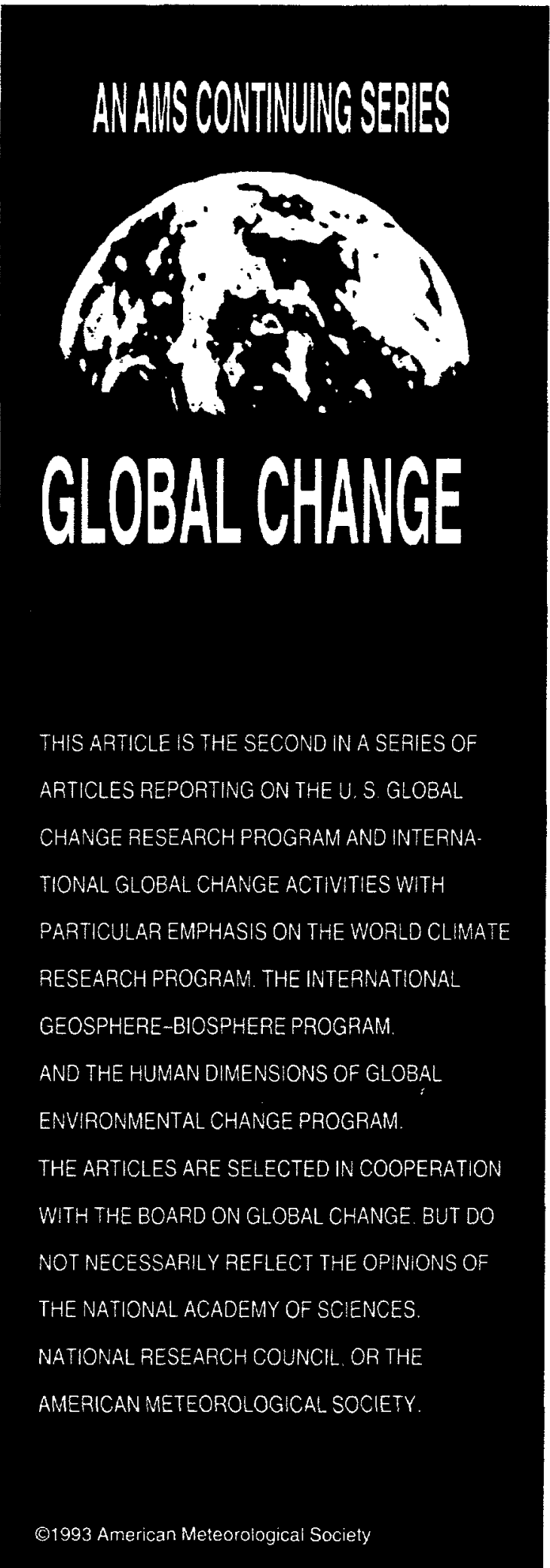

\section{A New Perspective on Recent Global Warming:}

\section{Asymmetric Trends of Daily Maximum and Minimum Temperature}

Thomas R. Karl, ${ }^{\star}$ Philip D. Jones, ${ }^{+}$ Richard W. Knight, " George Kukla, ${ }^{\circledR}$ Neil Plummer, ${ }^{\star *}$ Vyacheslav Razuvayev, ${ }^{++}$ Kevin P. Gallo, ${ }^{\star}$ Janette Lindseay, ${ }^{\circledR 0}$ Robert J. Charison, ${ }^{\star \star \star}$ and Thomas C. Peterson*

\section{Abstract}

Monthly mean maximum and minimum temperatures for over $50 \%(10 \%)$ of the Northem (Southem) Hemisphere landmass, accounting for $37 \%$ of the global landmass, indicate that the rise of the minimum temperature has occurred at a rate three times that of the maximum temperature during the period $1951-90\left(0.84^{\circ} \mathrm{C}\right.$ versus $0.28^{\circ} \mathrm{C}$ ). The decrease of the diurnal temperature range is approximately equal to the increase of mean temperature. The asymmetry is detectable in ail seasons and in most of the regions studied.

The decrease in the daily temperature range is partially related to increases in cloud cover. Furthermore, a large number of atmospheric and surface boundary conditions are shown to differentially affect the maximum and minimum temperature. Linkages of the observed changes in the diurnal temperature range to large-scale climate forcings, such as anthropogenic increases in sulfate aerosols, greenhouse gases, or biomass burning (smoke), remain tentative. Nonetheless, the observed decrease of the diurnal temperature range is clearly important, both scientifically and practically.

"National Climatic Data Center, Federal Building. Asheville, North Carolina.

+Climatic Research Unit, School of Environmental Sciences, University of East Anglia, Norwich, Norfolk, England

- Lamont-Doherty Earth Observatory, Columbia University, Palisades, New York.

*Bureau of Meteorology, Melbourne, Australia.

${ }^{+}$Research Institute of Hydrometeorological Information, Obninsk. Kalugu, Russia.

- Climate Research Group, University of Wirswatersrand, South Africa.

***University of Washington, Department of Atmospheric Sciences and Institute for Environmental Studies, Seattle, Washington. 


\section{Background}

The mean monthly maximum and minimum temperatures are derived from an average of the daily maximum and minimum temperatures. The mean monthly diurnal temperature range (DTR) is defined as the difference between the mean monthly maximum and minimum temperatures. The dearth of appropriate databases that include information on the daily or mean monthly maximum and minimum temperature has previously impeded our ability to investigate changes in these quantities. The problem has historical roots. It arises because the climatological data that have been made accessible to the international community, by national meteorological or climate data centers throughout the world, do not normally include data with resolution higher than mean monthly temperatures. The data that are made available internationally are usually derived from the monthly climate summaries (CLIMAT messages) on the Global Telecommunications System (GTS), which do not include information on the maximum or minimum temperatures. The GTS is the means by which nearreal-time in situ global climate data are exchanged. Moreover, the problem has been exacerbated because the World Meteorological Organization's retrospective data collection projects such as World Weather Records and Monthly Climatic Data of the World have always been limited to mean monthly temperatures. This has forced climatologists interested in maximum and minimum temperatures to either develop historical databases on a country-by-country basis (Karl et al. 1991) or try to work with the hourly GTS synoptic observations. The former is a painstakingly slow process, and the latter has been limited by poor data quality and metadata (information about the data) and records of short duration (Shea et al. 1992).

The first indication that there might be important large-scale characteristics related to changes of the mean daily maximum and minimum temperatures was reported by Karl et al. (1984). Their analysis indicated that the DTR was decreasing at a statistically significant rate at many rural stations across North America. Because of data accessibility problems, subsequent empirical analyses continued to focus on data from North America over the next several years (Karl et al. 1986a; Plantico etal. 1990). By 1990, however, a U.S./ People's Republic of China (PRC) bilateral agreement organized by the U.S. Department of Energy and the PRC's Academy of Sciences provided the opportunity to analyze maximum and minimum temperatures from the People's Republic of China. Also about this time, the Intergovernmental Panel on Climate Change (IPCC) made arrangements with the Australian National Climate Centre to analyze maximum and mini- mum temperature data from southeastern Australia. The IPCC (1990) reported a significant decrease in the DTR from both of these regions. Meanwhile, work from another data exchange agreement, a bilateral agreement between the United States and the former USSR (Union of Soviet Socialist Republics), came to fruition as a dataset of mostly rural maximum and minimum temperatures was developed for the former USSR. Karl et al. (1991) reported on the widespread decrease of the DTR over the former USSR, PRC, and the contiguous United States that was reiterated by the IPCC (1992).

Additional data from other countries and updates to previous analyses have now been analyzed here and elsewhere. Additional data include the eastern half of Australia, Sudan, Japan, Denmark, northern Finland, some Pacific island stations, Pakistan, South Africa, and a few other long-term stations in Europe. Figure 1 shows the area of the globe that has now been analyzed for differential changes of the maximum and minimum temperature. The area now covers over $50 \%(10 \%)$ of the Northern (Southern) Hemisphere landmass, but still only about $37 \%$ of the global landmass.

\section{Observed changes of mean maximum, minimum, and diurnal range}

\section{a. Spatial and season patterns of the contemporary trends}

Daily maximum and minimum temperatures from more than 2000 stations were available for analysis in the countries shaded in Fig. 1 during the period 1951 to 1990 (except Sudan and the former USSR, which had data through 1987 and 1989, respectively). Selected subsets of these data were averaged within various regions of each country. Each region represents a compromise between climatic homogeneity and an adequate number of stations within its boundaries to reduce sampling error. The base period for calculating departures from the average included the years 1951-90 (or slightly fewer years in some countries, e.g., Sudan and the former USSR). The regions are delineated in Fig. 2 where, similar to other largescale studies of the change of the mean annual temperature (Jones et al. 1986a,b; Jones 1988), the average of the trends of the mean annual maximum and minimum reveals a general rise of temperature. $A$ decrease of the minimum temperature within any region is uncommon but is somewhat more frequent for the maximum temperature, as seen over the United States and the PRC. The differential rate of warming between the maximum and minimum temperatures is 


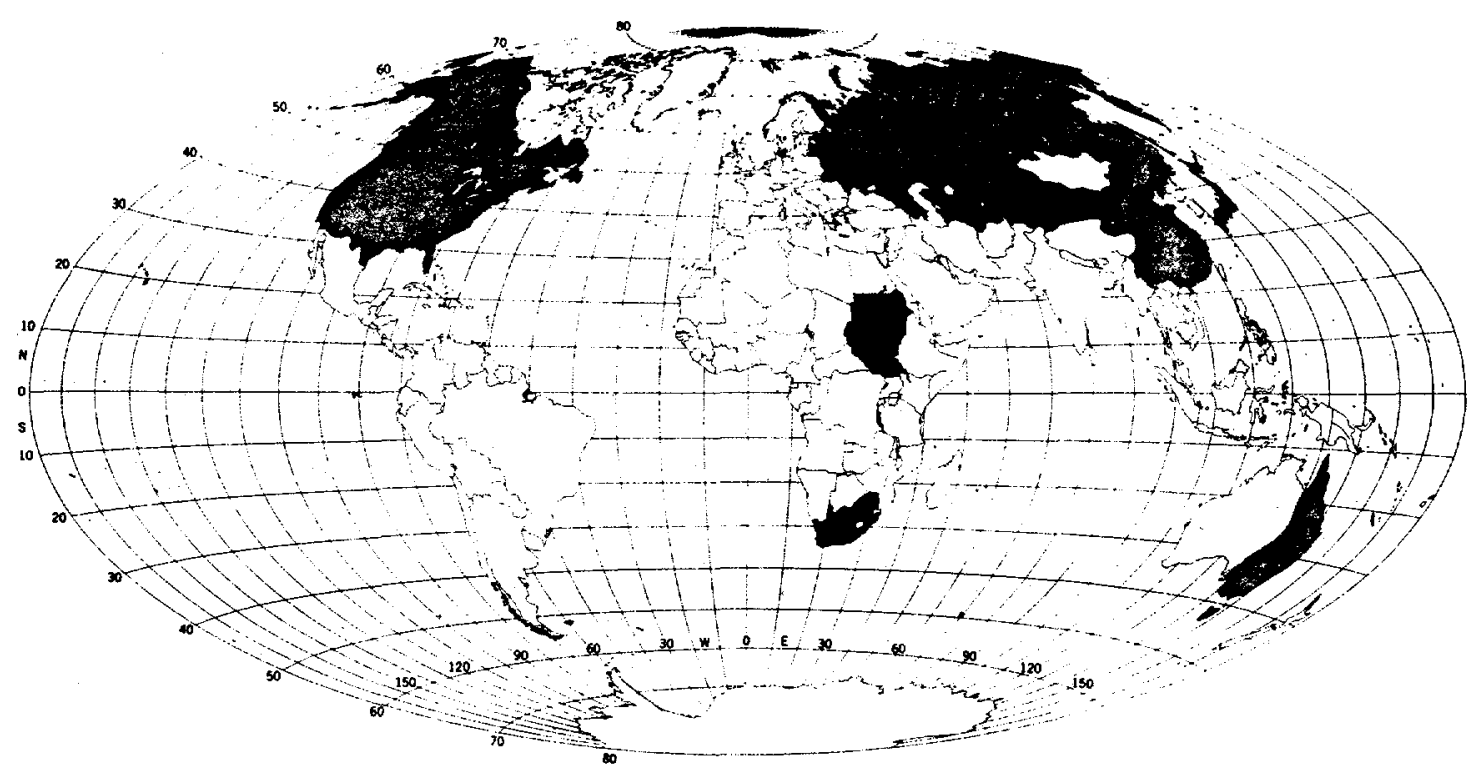

Fig. 1. Shaded areas represent areas of the world that have been analyzed for changes of mean maximum and minimum temperature.

apparent, with only a few regions reflecting an increase of the DTR. These weak exceptions occur in central Canada and southeasternmost Australia.

There are some seasonal variations of the rates of decreasing DTR, but they vary from country to country (Table 1). In Japan the decrease is not evident during summer, and it is not as strong during this season over the PRC. In the United States the decrease is weak during spring but quite strong during autumn. Alaska has strong decreases throughout the year, but Canada has only moderate decreases during summer and autumn. Over the former USSR the decrease in the DTR is significant throughout the year but somewhat weaker during the winter. Over Sudan, the rate of the DTR decrease is strong in all seasons except during the summer rainy season, where rains have been very sparse over the past few decades. Over South Africa, the DTR strongly decreases in the Southern Hemisphere spring, but actually increases slightly during autumn. In the eastern half of Australia the decrease of the DTR is apparent throughout the year but weakest during the Southern Hemisphere summer.

When collectively considered, $60 \%$ of the trends in Table 1 reflect statistically significant decreases of the DTR. A test for a change point in the trend (Solow 1987) indicates that for most seasons and areas there is insufficient evidence to suggest a statistically significant change point in the rate of the decrease.

The trends can be area weighted to reflect the overall rate of DTR decrease. Table 2 shows the decrease both north and south of the equator, but without any pronounced seasonal cycle in the Northern Hemisphere. The area of available data in the Southern Hemisphere is too small to make any general statements about trends in that portion of the globe, but the decrease in the Northern Hemisphere is quite apparent. The rate of the decrease in the DTR $\left(-1.4^{\circ} \mathrm{C} / 100\right.$ years $)$ is comparable to the increase of the mean temperature $\left(1.3^{\circ} \mathrm{C} / 100\right.$ years).

For all areas combined (Fig. 3), a noticeable differential rate of warming of the minimum relative to the maximum temperature began in the 1960 s. The minimum temperature has continued to warm relative to the maximum through the 1980s. The time series ends in 1989, the year after the major North American drought, as data from the former USSR were not available past 1989 . The variance of the time series is significantly impacted when such large regions drop out of the analysis, which is why the series ends prematurely. The end of the time series is significantly impacted by the major drought in North America during 1988, which leads to an enhanced DTR. Nonetheless, Fig. 3 reflects a gradual decrease of the DTR through much of the past several decades.

\section{b. Longer-term variations}

Unfortunately, the coverage of the globe with maximum and minimum temperature data is currently limited prior to 1951 . In the United States, a network of approximately 500 high-quality stations has remained intact back to the turn of the century, and in the former USSR a fixed network of 224 (165 stations if only rural 
MAX ANNUAL

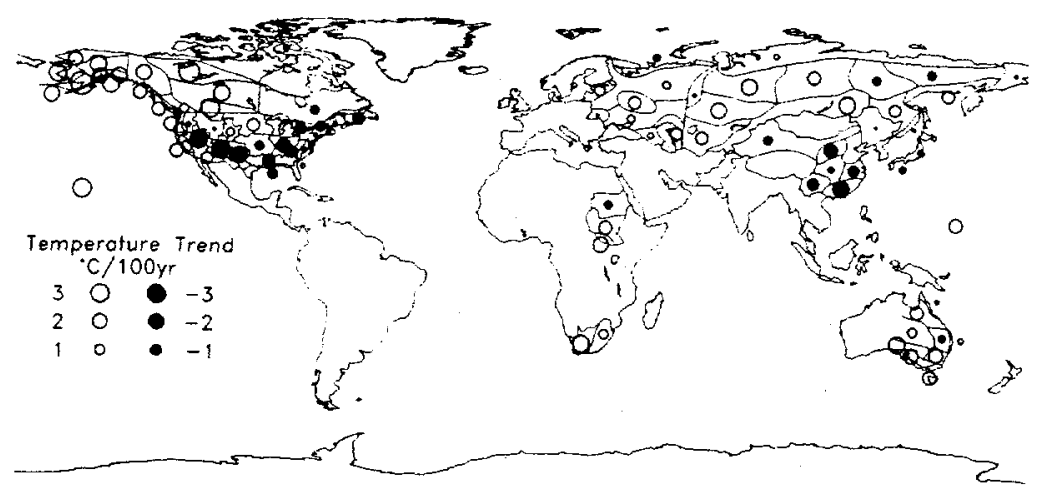

MIN ANNUAL

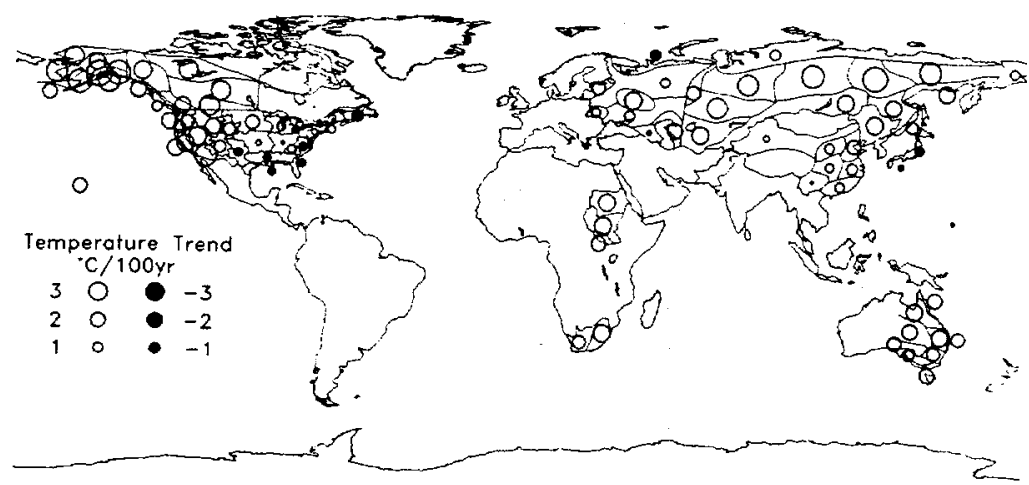

RANGE ANNUAL

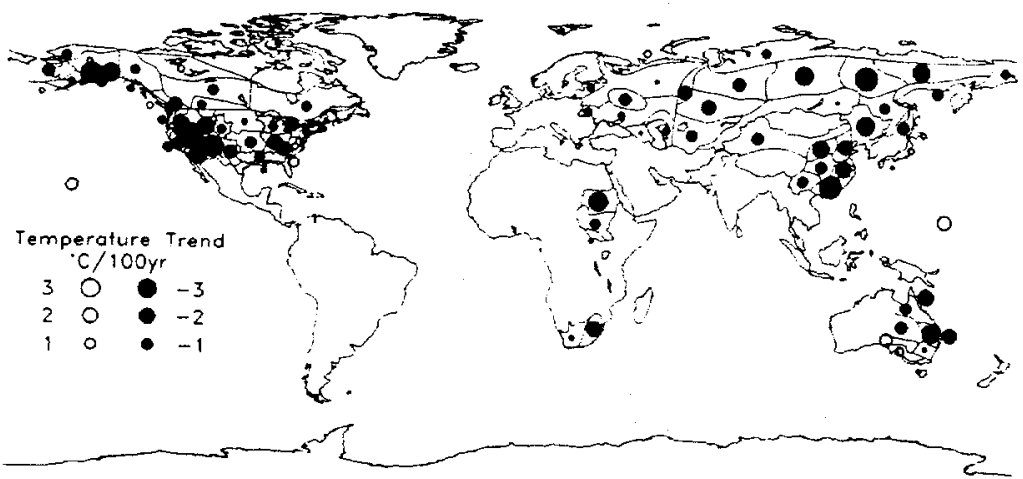

FiG. 2. Spatial patterns of annual trends of mean maximum, minimum, and diumal temperature range (mostly 1951-90) in degrees Celsius per one hundred years. Diameter of circles is proportional to the trend and solid (open) circles represent negative (positive) trends. Circles pertain to regions within each country except for island stations, e.g., in the South Pacific and Hawaii.

stations are used) stations is available back to the 1930s. Time series from these countries reflect significant (Fig. 4) decadal variations in the DTR, as evident during the dry 1930 s and early 1950 s in the United States. The general decrease of the DTR did not begin in the United States until the late 1950s, and the DTR decreased rather dramatically in the mid- to late 1970s over the former USSR as part of substantial increases in the minimum temperature. The decrease of the DTR in these two countries is a phenomenon of recent decades. Data are also available farther back in time for smaller areas and countries, notably Japan, eastern Australia, and South Africa. Figure 5 indicates that the decrease in the DTR in eastern Australia occurs rather gradually since the steep decline in the late 1940s. In South Africa the decrease is predominately due to the sharp decline in the early $1950 \mathrm{~s}$.

A very long record of maximum and minimum temperatures was available from the Klementinum-Observatory in Prague, Czech Republic, as well as a benchmark station from northern Finland. Figure 6 portrays a remarkable increase of the DTR at the Klementinum-Observatory from the early to the mid-twentieth century, with a substantial decrease since about 1950 . The increase coincides with the increase of mean temperature since the turn of the century, and the decrease occurs when the mean temperature reflects little overall change. In the first half of the nineteenth century, the DTR averages about $0.5^{\circ} \mathrm{C}$ lower compared with the latter part of the century. The DTR at Sodankylä, Finland, also displays a gradual decrease since 1950 , but contrary to the Klementinum-Observatory, the decrease is evident back to the turn of the century. The mean temperature at Sodankylä reflects little or no change. The high-frequency variability of the DTR at 
TABLE 1. Trends of temperature $\left({ }^{\circ} \mathrm{C} / 100 \mathrm{yr}\right)$ for annual and three-month mean maximum (MAX), minimum (MIN), and diurnal temperature range (DTR) based on a weighted average of the regions (by country) in Fig. 1. Additionally, trends significant at the 0.01 level (two-tailed $t$ test) are double underlined and those significant at the 0.05 level are single underlined. Trends with significant change points are denoted with an asterisk. The number of stations used to calculate the trends (in parentheses) and the time period relative to the trends is given for each country. PRC is the People's Republic of China, USA the contiguous United States of America, E. Australia the eastern half of Australia, USSR the former Union of Soviet Socialist Republics, and S. Africa the Republic of South Africa.

ב ALASKA (39) 1951-1990

ALASKA (39) 1951-1990

\begin{tabular}{|c|c|c|c|}
\hline Seasons & MAX & MIN & DTR \\
\hline$D-J-F$ & 6.0 & $\underline{8.8}$ & -2.8 \\
\hline$M-A-M$ & 3.1 & 6.3 & -3.2 \\
\hline$J-J-A$ & 0.9 & $\overline{2.4}^{*}$ & -1.5 \\
\hline$S-O-N$ & -1.4 & 0.4 & $-1.9^{*}$ \\
\hline ANNUAL & 2.1 & 4.5 & $\overline{\overline{2.4}}$ \\
\hline
\end{tabular}

\begin{tabular}{l|r|r|r} 
Seasons & MAX & MIN & DTR \\
D-J-F & 1.8 & 2.1 & -0.2 \\
M-A-M & $\underline{3.7}$ & $\underline{\overline{3.8}}$ & -0.1 \\
J-J-A & 0.5 & $\overline{\overline{1.4}}$ & $-\underline{\overline{0.9}}$ \\
S-O-N & -2.2 & -1.2 & -1.0 \\
ANNUAL & 0.9 & 1.5 & $-0.6^{*}$
\end{tabular}

USA (494) 1951-1990

\begin{tabular}{|c|c|c|}
\hline Seasons & MAX & MIN \\
\hline$D-J-F$ & -2.3 & -0.7 \\
\hline$M-A-M$ & 2.3 & $\underline{2.5}$ \\
\hline$J-J-A$ & $\overline{-0.3^{*}}$ & $\underline{\underline{1.0}}^{*}$ \\
\hline$S-O-N$ & -1.7 & $\overline{1.3}$ \\
\hline ANNUAL & $-0.6^{*}$ & 1.0 \\
\hline
\end{tabular}

SUDAN (15) 1951-1987

\begin{tabular}{|c|c|c|c|}
\hline Seasons & MAX & MIN & DTR \\
\hline D-J-F & -1.2 & 2.7 & $-\underline{\underline{3.9}}{ }^{*}$ \\
\hline$M-A-M$ & 0.4 & 3.3 & -2.8 \\
\hline$J-J-A$ & 2.8 & $\underline{2.1}$ & 0.7 \\
\hline$S-O-N$ & $\overline{1.4}$ & 2.5 & -1.1 \\
\hline ANNUAL & 0.9 & 2.7 & $-\overline{1.7}$ \\
\hline
\end{tabular}

\section{E. AUSTRALIA (44) 1951-1991}

\begin{tabular}{l|c|c|c} 
Seasons & MAX & MIN & DTR \\
D-J-F & $\underline{1.8}$ & $\underline{\underline{2.3}}$ & -0.4 \\
M-A-M & $\underline{\underline{1.6}}$ & $\underline{\underline{\underline{2.8}}}$ & -1.2 \\
J-J-A & 0.8 & 1.4 & -0.5 \\
S-O-N & 1.3 & $\underline{\underline{2.2}}$ & -0.9 \\
ANNUAL & $\underline{\underline{1.4}}$ & $\underline{\underline{\underline{2.2}}}$ & -0.7
\end{tabular}

both stations is less than that of their respective mean temperatures, but the converse is true for low-frequency variations.

USSR (FORMER) (165) 1951-1990

Seasons
D-J-F
M-A-M
J-J-A
S-O-N
ANNUAL

Seasons

D-J-F

$M-A-M$

$J-J-A$

$S-O-N$

ANNUAL

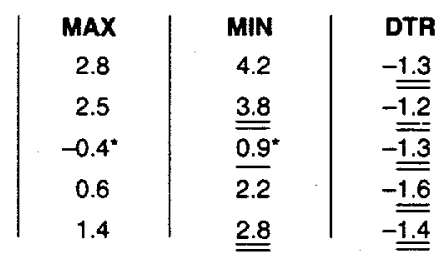

JAPAN (66) 1951-1990

\begin{tabular}{|c|c|c} 
MAX & MIN & DTR \\
-0.5 & -0.2 & -0.2 \\
-0.4 & -0.7 & 0.3 \\
0.5 & 0.0 & 0.4 \\
-0.3 & -0.5 & 0.2 \\
$-0.2^{*}$ & -0.4 & 0.2
\end{tabular}

PRC (44) 1951-1988

Seasons
$D-J-F$
$M-A-M$
$J-J-A$
S-O-N
ANNUAL

$$
\begin{array}{|c|c|r}
\text { MAX } & \text { MIN } & \text { DTR } \\
0.5 & \underline{3.5} & -\frac{-3.0}{=} \\
-0.8 & \underline{1.4} & -\underline{\underline{-2.2}} \\
-1.8 & -0.8^{*} & -\underline{\underline{-1.0}} \\
-0.6 & 1.0 & -\underline{-1.6} \\
-0.7^{*} & \underline{1.3} & -\underline{\underline{2.0}}
\end{array}
$$

\section{S. AFRICA (12) 1951-1991}

Seasons
D-J-F
M-A-M
$J-J-A$
S-O-N
ANNUAL

$\operatorname{MAX}$
0.8
$\underline{\underline{2.2}}$
1.3
-0.7
0.9

\begin{tabular}{|c|c|}
\hline MIN & DTR \\
\hline 2.0 & -1.2 \\
\hline$\overline{1.7}$ & 0.5 \\
\hline$\overline{1.3}$ & 0.0 \\
\hline 1.8 & -2.4 \\
\hline $1.7^{*}$ & -0.8 \\
\hline
\end{tabular}

If the data from the Klementinum-Observatory truly reflect the regional change of the DTR in central Europe, then the recent decrease of the DTR in this area is less persistent and less substantial than the increase prior to 1950. In light of the variations at the Klementinum-Observatory, what makes the results from Fig. 2 so remarkable is the fact that so many areas share an overall decrease of the DTR.

Recently, other investigators have also compiled information on the change of the DTR over other regions of the globe. Frich (1992) provides evidence to 
TABLE 2. Trends of temperature $\left({ }^{\circ} \mathrm{C} / 100 \mathrm{yr}\right)$ for annual and threemonth mean maximum (MAX), minimum (MIN), and diumal temperature range (DTR) for the areas denoted in Fig. 1 (less Pakistan, northern Finland, and Denmark). Percent of the land area covered for the Northern and Southern Hemisphere and the globe is denoted within parenthesis.

N. Hemisphere (50\%) 1951-1990

\begin{tabular}{l|r|r|r} 
Seasons & MAX & MIN & DTR \\
DJHF & 1.3 & 2.9 & -1.5 \\
M-AM & 2.0 & 3.2 & -1.3 \\
JJA & -0.3 & 0.8 & -1.1 \\
S-O-N & -0.4 & 1.3 & -1.7 \\
ANNUAL & 0.5 & 2.0 & -1.4
\end{tabular}

S. Hemisphere (10\%) 1951-1990

\begin{tabular}{l|r|r|r} 
Seasons & MAX & MIN & DTR \\
DJHF & 1.6 & 2.2 & -0.6 \\
M-A-M & 1.7 & 2.5 & -0.8 \\
JJA & 1.0 & 1.3 & -0.4 \\
S-O-N & 0.8 & 2.1 & -1.3 \\
ANNUAL & 1.3 & 2.0 & -0.8
\end{tabular}

GLOBE (37\%) 1951-1990

\begin{tabular}{l|r|r|r} 
Seasons & MAX & MIN & DTR \\
D-fF & 1.3 & 2.9 & -1.6 \\
M-A-M & 1.9 & 3.1 & -1.2 \\
J-A & -0.2 & 0.8 & -1.1 \\
S-O-N & -0.3 & 1.4 & -1.7 \\
ANNUAL & 0.7 & 2.1 & -1.4
\end{tabular}

indicate there has been a general decrease over Denmark since about 1950 , based on an analysis of severallong-term stations, most located in rural areas. Bücher and Dessens (1991) analyzed a long record of maximum and minimum temperatures from the Pic du Midi de Bigorre Observatory in the Pyrenees at a height of more than $2800 \mathrm{~m}$. Their analysis revealed a significant decrease of DTR since the late nineteenth century, but an inhomogeneity in the record prevented a continuation of the analysis beyond 1970 . Kruss et al. (1992) reported on changes of maximum and minimum temperature between the two $30-y r$ periods 1931-60 and 1961-90 over Pakistan. Despite considerable missing data, they managed to obtain at least 20 years of data from each of the two periods for 35 stations across Pakistan. Their analysis revealed a mix of decreasing and increasing changes of DTR. In our analysis of Pakistani data we could manage to identify only five stations with adequate data to analyze year-to-year changes; these were all located in the northern half of the country. These stations also depicted a decrease of the DTR.

\section{c. Relation to variations of the seasonal and} annual extremes

For a variety of practical considerations it is important to know whether the decrease in the mean DTR translates to a decrease in the extreme temperature range. Karl et al. (1991) provide evidence to suggest that indeed, over the United States and the former USSR (the only areas for which they had access to daily data), there was often a significant and substantial decrease in the seasonal and annual temperature extremes similar to the decrease in the seasonal and annual mean DTR. This similarity is also reflected in the time series of monthly extreme maximum and minimum temperature over Sudan (Jones 1992).

\section{d. Data quality}

A critical question arises related to the reliability of the data used to calculate the changes of the DTR. The data presented and discussed here have been subjected to various degrees of quality assurance. The degree to which precautionary measures have been taken to minimize data inhomogeneities varies considerably from country to country. In the United States,

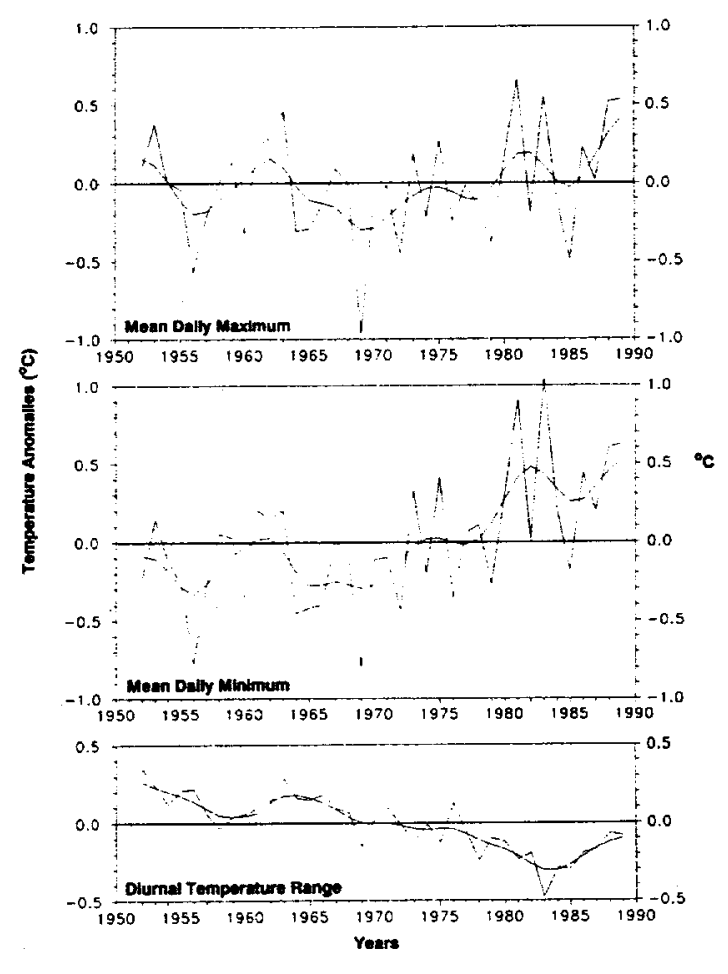

FIG. 3. Time series of the temperature anomalies of the annual mean maximum, minimum, and diumal temperature range for $37 \%$ of the global landmass (areas shaded in Fig. 1). Smooth curve is a nine-point binomial filter with "padded" ends. 

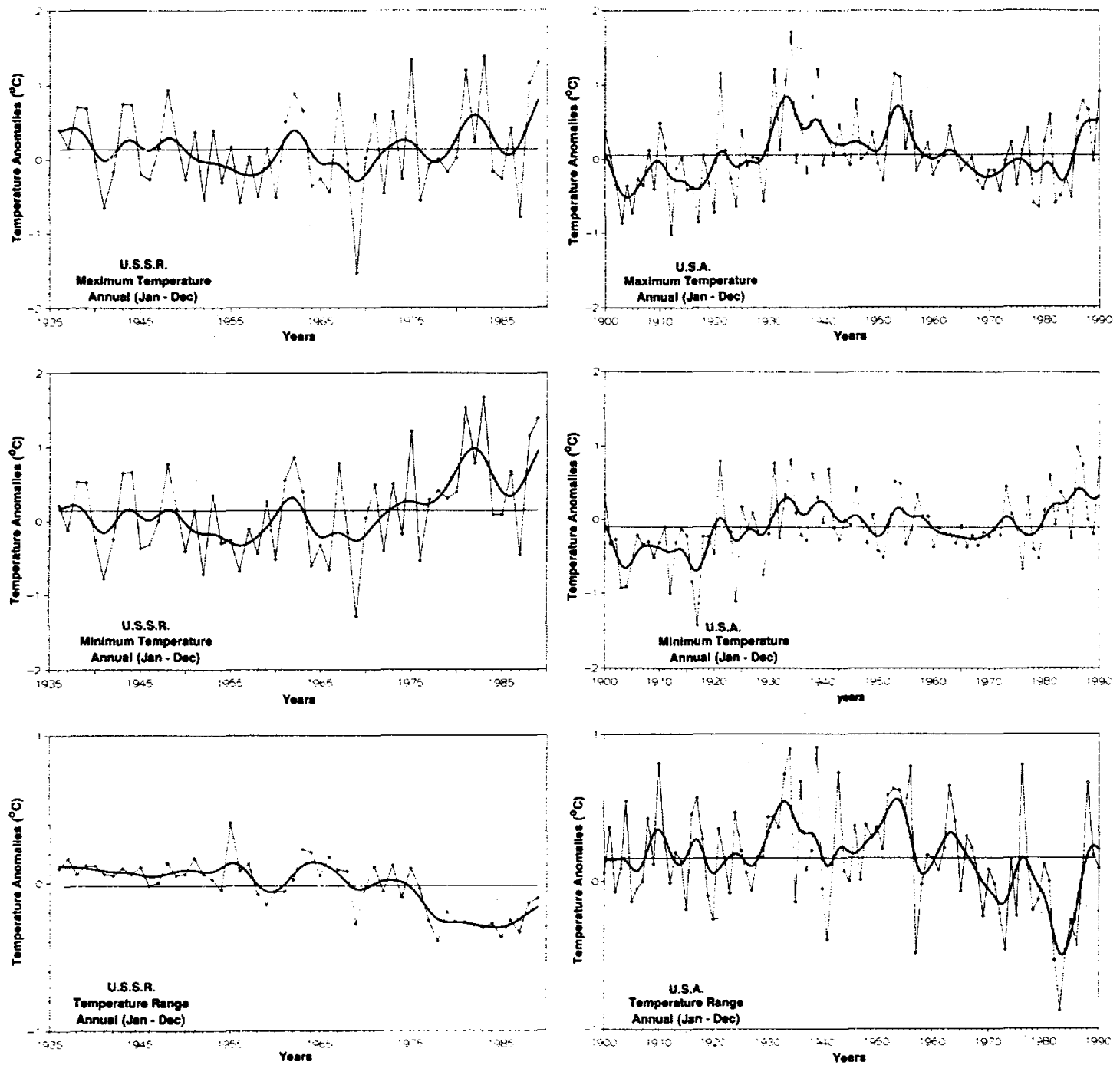

FIG. 4. Time series of the variations of the annual mean maximum, minimum, and diumal temperature range for the contiguous United States and the former USSR. Smooth curve is the same as Fig. 3 and trends since 1951 are depicted by the dashed line.

a fixed network of stations in the Historical Climatology Network (HCN) is used (Karl et al. 1990), which largely consists of rural stations that have been adjusted when necessary for random station relocations, changes in instrument heights, systematic changes in observing times (Karl et al. 1986a; Karl et al. 1986b), the systematic change in instruments during the midand late 1980s (Quayle et al. 1991), and increases in urbanization (Karl et al. 1988). The potential warm bias of the maximum introduced by the $\mathrm{HO83}$ series of thermometers (Gall et al. 1992) is not a factor in this network since the $\mathrm{HO} 83$ instrument is not used in the rural cooperative network that dominates the HCN (19 out of 20 stations).

Bulletin of the American Meteorological Society
In the former USSR the fixed network of 165 stations consists of rural stations (1990 populations less than 10000 and local surroundings free of urban development). The former USSR data have not been adjusted for any random or systematic inhomogeneities. Station histories, however, indicate there have not been systematic changes in network operation over the course of the past 50 years.

In Canada, the results reported here are derived from a set of 227 rural stations (population less than $10000)$. These data were selected from a network of 373 principal stations, but a large number of urban areas and stations, which relocated to airports, were eliminated from the analysis. 


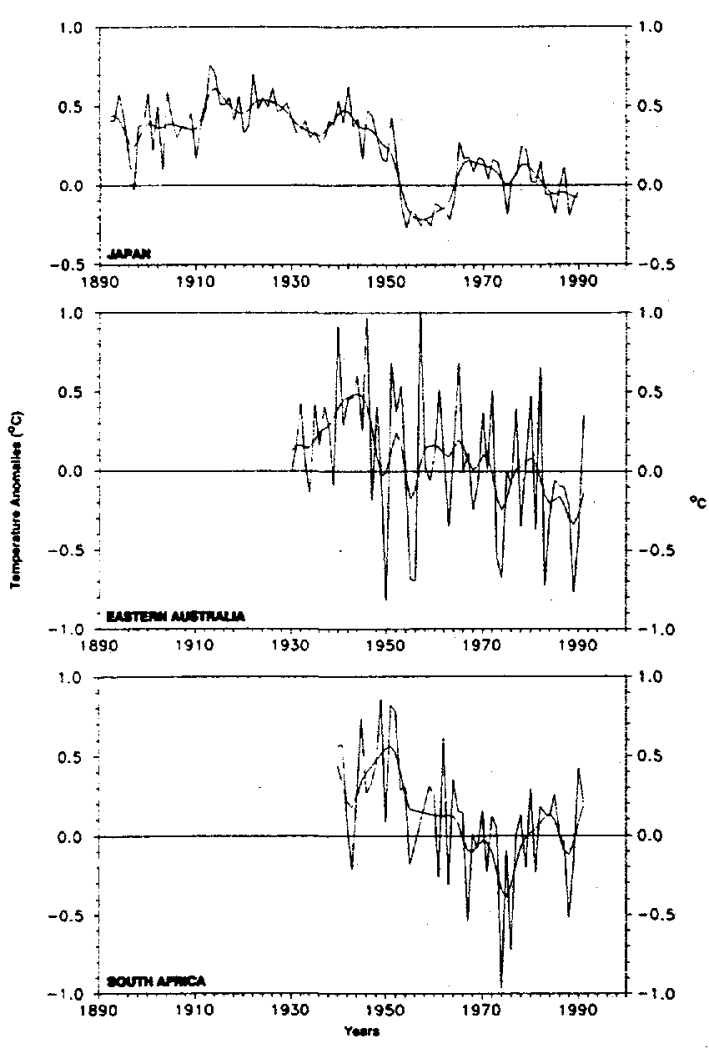

Fig. 5. Time series of the variations of the diurnal temperature range for Japan, eastern Australia, and South Africa. Smooth curve same as Fig. 3.

In Alaska, a network of 39 stations was used that included most stations operating in that state since the early 1950 s with the exceptions of stations in the major cities of Juneau, Fairbanks, and Anchorage. Once again no attempt was made to adjust for station relocations, and the stations consist of a mix of instrument types with some changes at specific sites.

Station histories from the PRC do not reflect any changes in instrumentation, instrument heights, instrument shelters, or observing procedures relative to the maximum and minimum temperature. Our analysis is based on a subset of more than 150 stations available to us. No attempt was made to correct for random station relocations in the fixed network of 44 stations we finally selected from the larger network. The potential impact of urbanization precluded the use of many stations. We eliminated all stations that were in or near cities with populations of more than 160000 .

All stations in Australia are currently undergoing thorough homogeneity testing (Torok 1992, personal communication) but were unavailable for this analysis. Instead, stations were selected based on the length of record and distance from major areas of urbanization. All of the stations used in Australia are from small towns or rural areas, many from post office "backyards."

Fewer than half of the 154 stations available from Japan were used in this analysis. Similar to the PRC, many stations were eliminated because of their proximity to major urban areas. An inspection of the station histories reveals a number of network "improvements" related to the automation of the temperature measurements in recent years. A full assessment of the homogeneity of the data awaits a detailed analysis. The station networks from Sudan and South Africa include some stations from urban areas, but countrywide decreases of the DTR are not overwhelmed by these stations. Incomplete information was available regarding systematic changes in instrumentation at these locations during the past several decades, but the data were inspected and adjusted when necessary for station relocations based on temperature differences with neighboring stations. In total, four stations in South Africa were adjusted using the procedures outlined by Jones et al. (1986a).

\section{Diurnal temperature range dependencies}

\section{a. Local effects}

As more data become available from a variety of countries it becomes difficult to dismiss the general decrease of the DTR over the past several decades as an artifact due to data inhomogeneities. Observing networks are rmanaged differently in each country. If local effects are significantly influencing the DTR, then at least three possibilities need to be explored. These include changes in urbanization, irrigation, and desertification. Evidence to support or refute the impact of these human-induced local and regional effects are discussed in subsequent subsections.

1) URBAN HEAT ISLAND

It is well known that the urban heat island often tends to manifest itself strongest during the nighttime hours (Landsberg 1981). In midlatitude North American cities the urban-rural temperature difference usually peaks shortly after sunset, then slowly decreases until shortly after sunrise, when it rapidly decreases, and for some cities actually vanishes by midday. In many cities, increases in urbanization would differentially warm the minimum relative to the maximum temperature.

A number of precautions have been taken to minimize the effect of increased urbanization in the climate records used in this analysis. In the contiguous United 
States, the corrections for urban development recommended by Karl et al. (1988) have been applied to the data, so any residual heat island effect in this analysis should not be an issue. In Canada, only stations with population less than 10000 were used in the analysis, and the average population of the cities in the proximity of the observing stations was slightly more than 1000. If the Canadian stations behave similarly to stations in the United States, the decrease of the DTR may be exaggerated by about $0.1^{\circ} \mathrm{C}$ due to urbanization. Similar values may also apply to Alaska. In the former USSR, the population limit for inclusion of any station into the network was 10000 , but in addition, no station could be within $1 \mathrm{~km}$ of any multistory urban development. If the impact of the effect of urbanization on the DTR in the former USSR is anything similar to that in the United States, the residual urban heat island effect on the DTR should be at least an order of magnitude smaller than the observed decrease of the DTR (nearly $1.5^{\circ} \mathrm{C}$ per $100 \mathrm{yr}$ ). In the PRC and Japan, a number of tests were conducted to identify the impact of urbanization on the DTR. Three networks of stations were categorized based on population. For the PRC, the categories included stations in proximity of cities with populations more than 1000000 , less than 160000 , and those with populations between these two thresholds.

Categories in Japan were based on 500000 and 50000 threshold values. The PRC had 23,42 , and 44 stations, while Japan had 17,71, and 66 stations, in each of the three population categories proceeding from high to low, respectively. Figure 7 shows that the decrease of the DTR actually becomes stronger in the PRC for the lowest population category compared with the moderate population category, while the trend of the average temperature continues to decrease. This suggests that urbanization effects in the PRC are dissimilar to those in the United States, as differential effects of the maximum and minimum temperature trends seem unaffected by urbanization in cities of 500 000 or less. In Japan, however, the impact of urbanization on the DTR is evident even in the lowest population category (less than 50000 ); this is even more apparent for the average temperature. Based on these analyses it would seem that urbanization effects in the PRC are unlikely to significantly impact the trends reported in Tables 1 and 2.

A previous paper by Jones et al. (1990) investigated the impact of increasing urbanization in the land database used by the IPCC $(1990,1992)$ to calculate
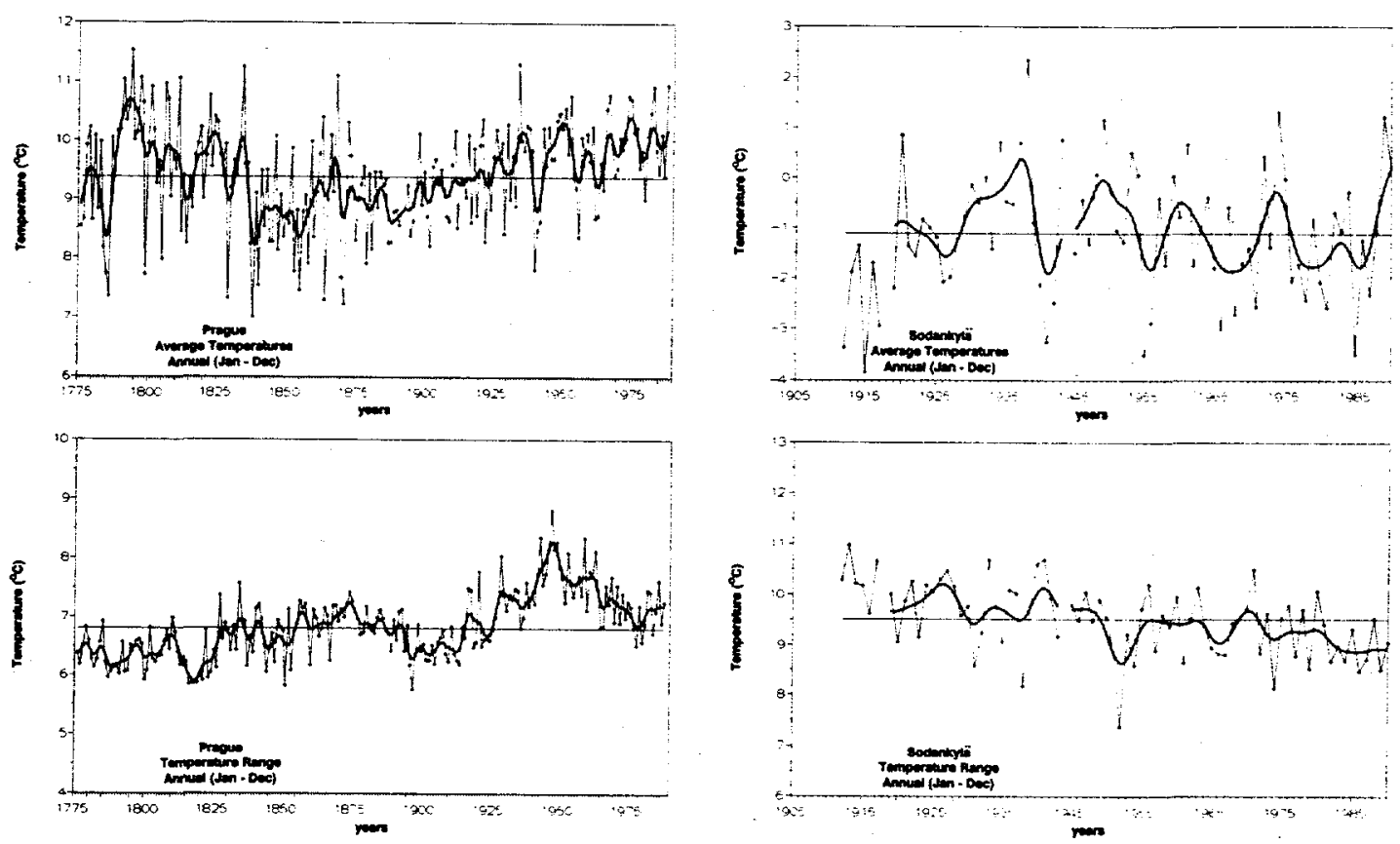

FiG. 6. Time series of the variations of the annual diurnal temperature range and the annual mean temperature from two long-term stations: Sodankylä, Finland, which has been designated as a climate reference station, and the Prague Klementinum-Observatory, Czechoslovakia. Smooth curve same as Fig. 3. 
changes of global temperature. The conclusion from the work of Jones et al. (1990) was that any residual urban bias in the land-based average temperature records was about $0.05^{\circ} \mathrm{C}$ during the twentieth century. A comparison of the average temperature trends derived from the stations used in Tables 1 and 2 with the stations used by Jones (1988) revealed differences in trends from country to country, but virtually identical trends of temperature (within $0.02^{\circ} \mathrm{C}$ per 100 yr) were found when all areas depicted in Fig. 1 were considered. This suggests that the degree of urbaninduced bias in these two datasets are of similar magnitude over the past 40 years, despite the use of substantially different station networks.

\section{2) IRRIGATION}

It can be argued that increases in irrigation may account for the decrease in the DTR. The evaporation associated with soil moisture would convert sensible to latent heat and thus significantly reduce daytime temperature. In order to test this hypothesis, the correlation coefficient (both Pearson product moment and the Spearman rank) was calculated using the values of the trends of the DTR and the change in land area under irrigation from 1950 to 1987 (U.S. Department of Commerce 1950,1988 ) for each of the regions delineated in Fig. 2. No relationship was found be-

TABLE 3: Stations and years used to identify the sensitivity of the diurnal temperature range to various climatic variables.

\begin{tabular}{l|c}
\hline Stations & Years \\
\hline Sacramento, CA & $1961-69$ \\
Tallahassee, FL & $1962-70$ \\
Indianapolis, IN & $1966-74$ \\
Worcester, MA & $1961-69$ \\
Bismarck, ND & $1973-81$ \\
Scotts Bluff, NE & $1971-79$ \\
Reno, NV & $1961-69$ \\
Oklahoma City, OK & $1975-83$ \\
Pittsburgh, PA & $1961-69$ \\
Columbia, SC & $1971-79$ \\
San Antonio, TX & $1973-81$ \\
Seattle/Tacoma, WA & $1971-79$ \\
Spokane, WA & $1966-75$ \\
Green Bay, WI & $1971-79$ \\
\hline
\end{tabular}

tween the change in the DTR and the increase of irrigated lands, and in fact many of the largest decreases of the DTR were associated with areas with the smallest increases of irrigation. Despite the significant decreases of the DTR over the past several decades and the relatively large increases of irrigation within the United States over the past 40 years compared to other countries, it seems unlikely that increases of irrigation can be regarded as a serious explanation for the widespread decreases of the DTR.

\section{3) Desertification}

The converse of the theoretical effects of irrigation would result from increased desertification, i. e., an increase of the DTR. This might arise from poor land practices such as overgrazing or deforestation. Given the mid-and high-latitude bias of the results reported here, it seems unlikely that desertification would have a significant impact on the results reported in Tables 1 and 2. Moreover, this effect would tend to make the magnitude of the reported decreases too small, especially during the warm season, as desertification would increase the maximum and decrease the minimum.

\section{b. Climatic effects}

Since it seems unlikely that any of the humaninduced local effects can provide a satisfactory answer to the widespread decrease of the DTR, a number of climatic variables that differentially affect the maximum and minimum temperature were analyzed to discern which climatic variables most strongly affect the DTR. More than 50000 days of climatic observations were selected from the stations listed in Table 3 during periods of consistent measurement procedures for the variables defined in Table 4 . The rationale for selection of variables to be studied was based on a priori information. For example, increases of the DTR over land have previously been related to snow cover ablation as simulated by the U. K. Meteorological Office's General Circulation Model (GCM) with doubled $\mathrm{CO}_{2}$ (Cao et al. 1992). Our analysis included more than 4000 cases of snow cover. It is well known that the ability of the surface boundary layer to absorb, radiate, transform, and mix sensible heat differentially affects the maximum and minimum temperature. The relative humidity and cloudiness are two important climate variables that influence these surface-layer properties. In this analysis cloud-related information was contained in two climatic variables: the sky cover (in tenths) and an index of the ceiling height. The ceiling height (CIG) was categorized into seven categories. The cloud ceiling is defined as height above ground of the lowest cloud layer that covers $50 \%$ or more of the sky. The wind speed is an effective measure of the degree of mixing within the 
surface boundary layer as it affects and interacts with the frequency or intensity of inversions and super-diabatic lapse rates. Additionally, the DTR is affected by the seasonal and latitudinal changes of incoming solar radiation as well as the magnitude of day-to-day temperature differences. The inclusion of TRAD can also be regarded as a surrogate for temperature especially when used in conjunction with the othervariables listed in Table 4. Karl et al. (1986b) demonstrate the impact of the interdiurnal temperature difference on the maximum and minimum temperature. These day-today changes of temperature are largely controlled by the thermal advection associated with synoptic-scale cyclones and anticyclones.

All of the variables in Table 4 were used in a multiple regression analysis. Variables were regressed against the square root of the DTR, as opposed to the actual DTR, because the DTR is bounded by zero. Without the transformation, nonnormal residuals result in multiple linear regression analyses, making it more difficult to interpret the results. Figure $8 a$ indicates that the partial correlation coefficients of each variable to the DTR are often significantly different from the simple linear correlation coefficients, making it difficult to speculate on the effect of changes in any one variable without knowing (or assuming constancy) the changes in the other variables. Given the huge sample size, very low correlations have high statistical significance (even considering the day-to-day persistence of the DTR). On a local basis, a generalized multiple linear regression model (one model for all stations and all days) based on the seven climatic variables in Fig. 8 a explains about $55 \%$ (53\% without the square-root transformation) of the daily variance of the DTR. Although the explained variance is substantial, it is apparent that other factors may also need to be considered with respect to explaining the variations of the DTR (e.g., better representations of the atmospheric stability, external forcing factors, more precise techniques to calculate the mean quantities used in the analysis), or that the relationships are not adequately expressed by a linear equation or both.

On a variable-by-variable basis the signs of all the partial correlations make qualitative physical sense. It is interesting to note the higher partial correlation of $\triangle T M P$ compared with the simple correlation coefficient (Fig. 8a) as the correlation between TRAD and $\triangle T M P$ mask the importance of $\triangle T M P$ in influencing DTR. The decrease of the partial correlation relative to the simple correlation for the variables $\mathrm{RH}, \mathrm{ClG}$, and SKY is to be expected because changes among each of these variables are related to each other. The decrease in the partial correlation of SNOW is particularly noteworthy, especially since Cao et al. (1992) attribute the ablation of snow cover in their model to an increase in the DTR. The empirical results in Fig. $8 \mathrm{a}$ suggest that SNOW is only weakly related to the DTR, especially compared to other variables.

In order to investigate the linearity, or lack thereof, of the relationships implicit in Fig. $8 a$, the data were 
TABLE 4. Definitions and abbreviations of the climatic variables used to test the sensitivity of the diumal temperature range.

\begin{tabular}{lc}
\hline Variables & Abbreviations \\
\hline Diumal temperature range (daily max-daily min) & DTR \\
Snow cover (binary, if snow depth $2.54 \mathrm{~cm}$ ) & SNOW \\
Mean relative humidity (0600 LST and 1500 LST) & RH \\
Mean wind speed (0600 LST and 1500 LST) & WS \\
Mean sky cover (0600 LST and 1500 LST) & SKY \\
Mean ceiling (0600 LST and 1500 LST) & CIG \\
Total daily top of the atmosphere solar radiation & TRAD \\
Day-to-day temperature differences & STMP \\
(ITMP - TMP $_{-1}$ + ITMP - TMP +1 ) & \\
\hline
\end{tabular}

TRAD increases is related to the decrease in intensity of the day-to-day changes of temperature during the warm season. Rossby waves and extratropical cyciones have reduced amplitude, speed, and intensity during the warm season.

A change in sign of the partial correlation coefficient of SNOW with the DTR (Fig. $8 \mathrm{~b}$ ) suggests that the length of night relative to the TRAD is a significant factor when considering the impact of changes in snow cover on the DTR. In the northern United States, around the winter solstice, TRAD is relatively low. Snow on the ground at this time of the year is important because of its excellent insulation (reduces heat flow from the soil) and high emissivity, which help lower the nighttime mini-

partitioned by TRAD. Figure $8 b$ provides strong evidence to suggest that the relationships change with the amount of TRAD. In particular, the partial correlation coefficients of RH, WS, and SKY become stronger as TRAD (and thus temperature) increases. This probably has more to do with a reduction of the maximum temperature than an increase of the minimum. During daylight hours high values of the $\mathrm{RH}$, WS, and SKY are indicative of higher albedos, higher potential evapotranspiration, higher atmospheric water vapor absorption of incoming radiation, and larger than normal mechanical mixing. These factors act to retard the maximum temperature that would otherwise result from high intensity TRAD, which would be manifested as sensible heat within the surface boundary layer. The nonlinearity of RH as TRAD increases is substantially greater than WS (Fig. 8b). As the TRAD to the surface increases the temperature increases, and a greater portion of the TRAD can be used for evaporation compared with raising surface temperature, as would be anticipated by the ClausiusClapeyron equation when integrated to obtain saturation vapor pressure as a function of temperature.

The reduction of the partial correlation of TRAD with the DTR after partitioning by TRAD (Fig. 8 b) relates to the balance between long nights and short days. During the late autumn and early winter in the northern half of the United States (areas that include the lowest partition of TRAD), a moderate increase in the TRAD (by interseasonal and latitudinal variations) generally results in a higher DTR. Contrarily, in the warm half of the year, TRAD and its associated daylight are more than ample so that the relation between TRAD and DTR is near zero. In fact, a further partition of the TRAD into a very high category leads to negative partial correlations between TRAD and the DTR.

The reduction of the partial correlation of $\triangle T M P$ as mum. During the daytime the TRAD is already low, so the amount of solar radiation reflected by the snow cover is no longer as important. As a result, snow cover at this time of the year and these latitudes leads to an increase in the DTR. This is not the case as the season progresses or the latitude decreases, as reflected by the negative partial correlations (lower values of DTR with snow cover) associated with the highest category of TRAD; there were still nearly 1000 cases of snow cover. The data suggest that snow cover ablation will not necessarily lead to an increase of the DTR.

From the aforementioned analysis, it is apparent that there are many factors, often intricately related, that affect the DTR. Many of the variations in these variables are very much related to a greenhouse effect, some of which may be anthropogenically induced. Overall, the two variables related to changes in cloudiness, sky cover, and ceiling height explain the greatest portion of the variance of the DTR. Changes in cloudiness should be one of the first considerations in searching for an explanation of the observed decrease of the DTR (Fig. 2). Indeed, when large continental scales are considered, the relationship between cloud amount (or sky cover) and the DTR is quite impressive (Fig. 9). Plantico et al. (1990) have already demonstrated that the decrease in the DTR over the United States is strongly linked to an observed increase in daytime and nighttime cloud cover and a lowering of cloud ceilings.

Is there a general increase in cloud cover over much of the globe? Empirical evidence by HendersonSellers $(1986,1989,1992)$ and Jones and HendersonSellers (1992) suggests this may be the case over Canada, the United States, Europe, the Indian subcontinent, and Australia. Analyses of cloud cover changes over the PRC from a network of 58 stations 
across the PRC are inconclusive, but there is evidence for a decrease in the sunshine (a $2 \%$ to $3 \%$ decrease in sunshine from the 1950 s to the 1980 s). The quality of the cloud data (and perhaps the sunshine data) is questionable because the correlation between monthly anomalies of sunshine and cloudiness at many sites is not high. Analyses of changes in cloudiness over the former USSR by Balling (1992, personal communication) reveal a general increase of cloud cover $(3.5 \%)$ during the period 1965-86 with stratus and stratocumulus clouds (low ceilings) increasing in frequency by about $2 \%$. He also found considerable interannual and interstation variability, so the quality of these data could also be called into question. Nonetheless, the trend over the former USSR is consistent with a decrease in the DTR. Frich (1992) and Bücher and Dessens (1991) also found that decreases in the DTR in Denmark and at the Pic du Midi de Bigorre Obser-

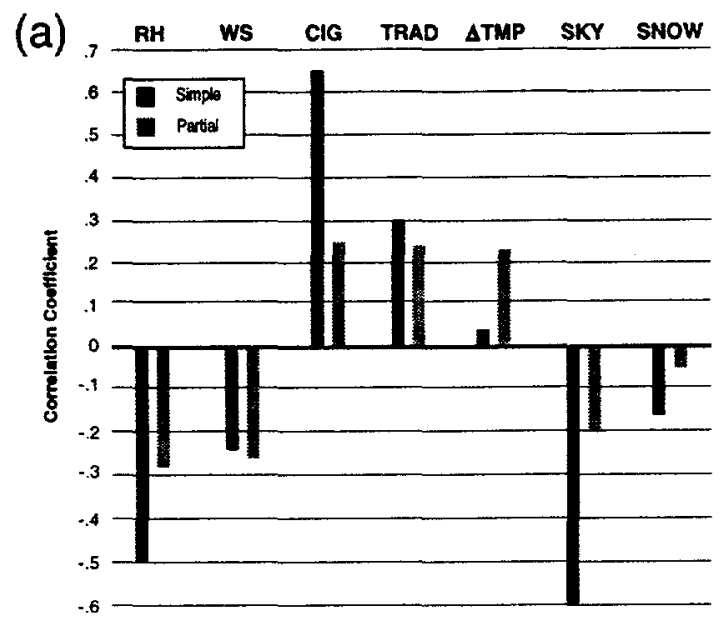

(b) $\mathrm{RH}$ WS CIG TRAD $\triangle T M P$ SKY SNOW

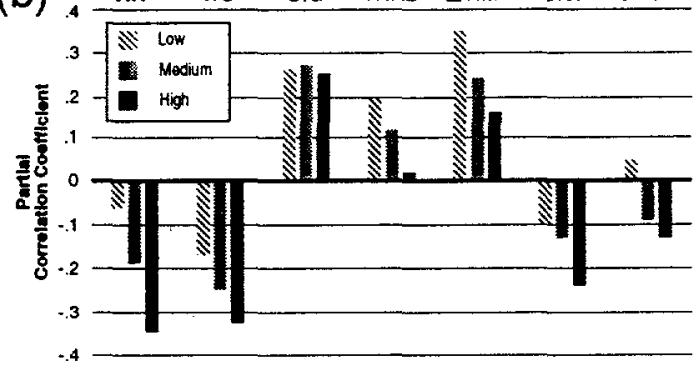

FIG. 8. Relationship between various climate variables and the diurnal temperature range. (a) Simple and partial correlation coefficients (removing the effects of all other variables) between each variable (defined in Table 4) and the diurnal temperature range. (b) Partial correlation coefficients of each variable for cases partitioned by the total daily solar radiation at the top of the atmosphere 170 $\mathrm{Wm}^{-2}$ (low); $271 \mathrm{Wm}^{-2}$ (high); remainder (moderate) vatory occurred with an increase in cloudiness. An analysis of changes in cloud cover over Japan, using many of the same stations selected for the analysis of the maximum and minimum temperatures, indicates cloud cover may have increased on an annual basis by nearly $1 \%$ since 1951 , but there is no apparent response in the DTR. Changes in sunshine in Japan are not altogether consistent with the increase in cloud cover, but a new sunshine instrument was introduced into the network in 1986.

\section{Large-scale anthropogenic effects}

\section{a. Greenhouse gases}

Interest in the potential change of the DTR with increasing anthropogenic greenhouse gases has prompted several modeling groups to publish information from their models regarding the projected change in the DTR from doubled $\mathrm{CO}_{2}$ experiments. Table 5 summarizes the results of these models. For the GCM experiments, the magnitude of the decrease is small relative to overall warming of the mean global temperature. Moreover, these experiments reflect a level of $\mathrm{CO}_{2}$ increase well in excess of present-day values, so even smaller changes should be expected in the observed temperature record.

Cao et al. (1992) also conducted a number of experiments with a one-dimensional radiative-convective model (RCM), which showed that the decrease in the diurnal temperature range with doubled $\mathrm{CO}_{2}$ in that model is primarily due to a water vapor feedback. Only a $0.05^{\circ} \mathrm{C}$ reduction in the DTR was observed when the absolute humidity was held constant. Table 5 indicates that the increased sensible heat exchange and evaporation are also important factors leading to a reduction in the DTR in RCM simulations with enhanced $\mathrm{CO}_{2}$.

Interestingly, the ratio of the DTR decrease relative to the increase of the mean temperature in the RCM compared with the GCM is closer to the observed ratio over the past several decades (Table 5). The RCM omits the positive feedbacks to the DTR from reductions in cloud and surface albedo as contained in the GCM simulations (Cao et al. 1992). This tends to increase the DTR because of reduced atmospheric (cloud cover) and surface (snow cover) albedo. Other GCM simulations have both increases and decreases in cloudiness with global warming: decreases in much of the troposphere, but increases in the high troposphere, low stratosphere, and near the surface in high latitudes (Schlesinger and Mitchell 1985). If the observational evidence is correct regarding the tendency for a general increase in cloud cover over the land (which now seems likely), then this could help explain the 
TABLE 5. Summary of modeling results with respect to the relationship between doubled $\mathrm{CO}_{2}$ concentrations and changes in the diurnal temperature range (DTR) and the maximum and minimum temperatures. Abbreviations are $1 T$ is the equilibrium global temperature change $\left({ }^{\circ} \mathrm{C}\right)$ for doubled $\mathrm{CO}_{2}$ concentrations, $\triangle \mathrm{DTR}$ is the equilibrium global change of the DTR $\left({ }^{\circ} \mathrm{C}\right)$ for doubled $\mathrm{CO}$, concentrations, $\mathrm{CCC}$ is the Canadian Climate Centre, GISS is the Goddard Institute for Space Studies, and UKMO is the U. K. Meteorological Office.

\begin{tabular}{|c|c|c|c|c|c|c|}
\hline \multirow[t]{2}{*}{ GCM Model } & \multirow[t]{2}{*}{ Author } & \multicolumn{2}{|c|}{ Resolution } & \multirow[t]{2}{*}{ Ocean } & \multirow[t]{2}{*}{$T_{\omega a}$} & \multirow{2}{*}{ DTA $_{\infty a}$} \\
\hline & & Horiz. & Vert. & & & \\
\hline $\mathrm{CCC}$ & Boer 1989 & T32 & 10 & Mixed layer & 3.5 & -0.28 \\
\hline GISS & Rind et al. (1989) & $8^{\circ} \times 10^{\circ}$ & 9 & Mixed layer & 4.2 & $\begin{array}{l}-0.7 \text { (sum, USA) } \\
-0.1 \text { (ann, USA) }\end{array}$ \\
\hline UKMO & IPCC (1990) & $8^{\circ} \times 10^{\circ}$ & 11 & Mixed layer & 5.2 & -0.17 \\
\hline UKMO & Cao et al. (1992) & $5^{\circ} \times 7.5^{\circ}$ & 11 & Mixed layer & 6.3 & -0.26 \\
\hline
\end{tabular}

Radietive Convective Model (Cao et al. 1992)

\begin{tabular}{lc|c|c} 
Type & Maximum $\mathrm{T}_{\odot q}$ & Minimum & DTR \\
\hline Fixed absolute humidity & $\mathrm{X}$ & $\mathrm{X}$ & -0.05 \\
No surface turbulence & 2.5 & 2.9 & -0.4 \\
No evaporation & 2.3 & 2.9 & -0.6 \\
Full surface exchange & 1.5 & 2.2 & -0.7 \\
\end{tabular}

large discrepancy between the observed data and the model projections of the ratios of the decrease in the DTR range relative to the mean temperature increase. This assumes, of course, that the recent warming is induced by increases in anthropogenic greenhouse gases. On the other hand, this raises questions regarding the cause of the apparent change in cloudiness and how it has impacted the mean temperature.

The ability of present day GCMs to adequately simulate projected changes in the DTR with enhanced $\mathrm{CO}_{2}$ is also affected by surface parameterizations of continental-scale evaporation. As Milly (1992) points out, present-day GCMs can overestimate the surface evaporation because of the failure to properly account for the cooling that occurs with the evaporation. Milly (1992) raises concerns about the veracity of the results from studies of soil moisture changes induced by an increase of greenhouse gases. Accurate projections of the change in the surface boundary-layer DTR with increases of anthropogenic greenhouse gases will be strongly dependent on adequate simulation of these processes.

Given the dependency of the DTR on surface-layer processes, interactions with the land surface, and cloudiness, all areas of significant uncertainties within present-day GCMs, it may not yet be possible to adequately project changes of the DTR with enhanced concentrations of greenhouse gases.

\section{b. Tropospheric aerosols}

It has recently been shown that increases in sulfate aerosols over and near industrial regions can significantly impact the earth's surface heat balance (Charison et al. 1992). Charlson et al. (1991) and Charlson et al. (1992) provide evidence to indicate that the anthropogenic increase of sulfate (and carbonaceous) aerosol is of sufficient magnitude to compete regionally with present-day anthropogenic greenhouse forcings. This forcing is confined primarily to the Northern Hemisphere and is a combination of direct aerosol forcing (especially over the land) and indirect aerosol forcing leading to increases in cloud albedo (especially over the marine environment). At present, Charlson et al. (1992) conclude that it is too uncertain to estimate the effects of sulfate aerosols on the lifetime of clouds (smaller droplet sizes leading to a decrease in the fallout rate) which presumably could lead to an increase in cloud cover. Charlson et al. (1991) provide the geographic pattern where direct aerosol forcing should be greatest. It is difficult to identify a direct relation between the pattern and magnitude of the decrease in the DTR (Fig. 2) and the anthropogenic radiative forcing calculated by Charlson et al. (1991). Moreover, Karl et al. (1986a) and Karl et al. (1986b) provide evidence to suggest that there is little change of the maximum relative to the minimum temperature in the United States for cloudiess skies even when the daily data are stratified by dewpoint and wind direction.

Recently, Penner et al. (1992) have argued that atmospheric aerosols from biomass burning also act to increase the planetary albedo both directly by clearsky planetary albedo increases and indirectly through 
increases in cloud albedo. Since biomass burning is most extensive in subtropical and tropical areas, this effect may be directly relevant only to a small portion of the data analyzed here.

Two tropospheric aerosol forcing agents (aerosols from sulfur emissions and biomass burning) have been identified that tend to increase the clear-sky albedo. Neither forcing is believed to have dominant infrared forcing. The question arises whether either of these forcings has acted to reduce the maximum temperature and thereby the DTR. In the United States and northern (and perhaps eastern) Europe, however, where we detected a significant decrease in the DTR, there has actually been a net decrease in sulfur emissions over the past several decades that would qualitatively appear to eliminate sulfate aero- sols as an influence on the DTR in these areas. There are reasons why such a conclusion may be premature. First, the climate forcing due to tropospheric aerosol loading is influenced both by the emission rate and the residence times of sulfate aerosol in the atmosphere. In the United States, at least, the effective heights, or stack heights, of the sulfur emissions have increased as a consequence of the U.S. Clean Air Act. This may have had an effect on the lifetime of the $\mathrm{SO}_{2}$ and sulfate aerosols

\section{Conclusions}

Strong evidence exists for a widespread decrease in the DTR over the past several decades in many
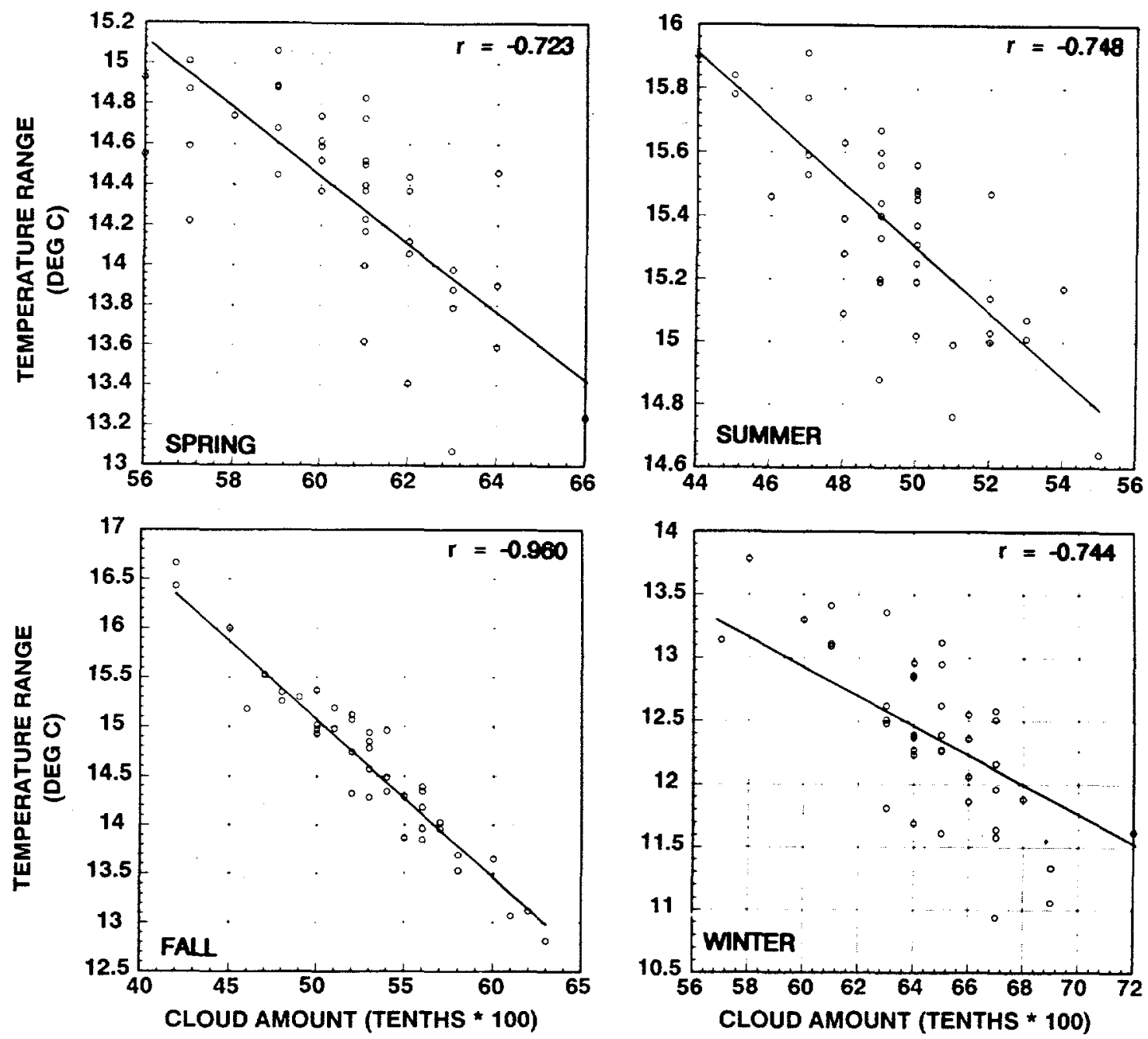

FIG. 9. Seasonal relationships between U.S. area-averaged cloud cover and the diurnal temperature range. 
regions of the globe. There are many possible climatic factors that affect the DTR, but indications are that cloud cover, including low clouds, has increased in many areas that have a decrease in the DTR. The increases in cloud cover could be indirectly related to the observed global warming and increases of greenhouse gases, related to the indirect effects of increases in aerosols, simply a manifestation of natural climate variability, or a combination of all three.

A robust answer regarding the cause(s) of the decrease in the DTR will require efforts in several areas. First, an organized global effort is required to develop relevant and homogeneous time series of maximum and minimum temperature along with information on changes of climatic variables that influence the DTR such as cloudiness, stability, humidity, thermal advection, and snow cover. Second, improvements in the boundary-layer physics and treatment of clouds within existing GCMs are critically important. Third, the treatment of both anthropogenic tropospheric aerosols and greenhouse gases must be realistically incorporated into GCMs with a diurnal cycle. Fourth, measurements need to be made to help clarify the role of aerosols. Finally, imaginative climate change detection studies that link the observed climate variations to model projections will be required to convincingly support any relation between anthropogenic-induced changes and the DTR.

It will be difficult to satisfactorily explain the observed changes of the mean temperature until an adequate explanation for the observed decrease in the DTR can be determined. Moreover, the practical implications of projected temperature changes and whether they are likely to continue will be even more difficult to assess.

Acknowledgments. This work was supported by a U.S. DOE' NOAA Interagency agreement and NOAA's Climate and Global Change Program.

We thank the following scientists for providing us with additional data: Dr. Reino Heino for the Sodankylä data and Dr. Takehiko Mikami for the Japanese data.

We also thank our referees, two of whom made their identity known to us, Drs. Ann Henderson-Sellers and Kevin Trenberth, for their insightful recommendations.

\section{References}

Bücher, A., and J. Dessens, 1991: Secular trend of surface temperature at an elevated observatory in the Pyrenees. J. Climate, 4, $859-868$.

Cao, H. X., J. F. B. Mitchell, and J. R. Lavery, 1992: Simulated diurnal range and variability of surface temperature in a global climate model for present and doubled $\mathrm{CO}_{2}$ climates. J. Climate, $5,920-943$.
Charlson, R. J., J. Langner, H. Rodhe, C. B. Leovy, and S. G. Warren, 1991: Perturbation of the Northern Hemisphere radiative balance by backscattering from anthropogenic sulfate aerosols. Tellus, 43AB, 152-163.

-, S. E. Schwartz, J. M. Hales, R. D. Cess, J. A. Coakley, Jr., J. E. Hansen, and P. J. Hoffmann, 1992: Climate forcing by anthropogenic aerosols. Science, 255, 423-430.

Frich, P., 1992: Cloudiness and diumal temperature range. Fifth International Statistical Climatology Meeting. Environment Canada, Toronto, 91-94.

Gall, R., K. Young, R. Schotland, and J. Schmitz, 1992: The recent maximum temperature anomalies in Tuscon: Are they real or an instrumental problem? J. Climate, 5, 657-665.

Henderson-Sellers, A., 1986: Cloud changes in a warmer Europe. Clim. Change, 8, 25-52.

- 1989: North American total cloud amount variations this century. Glob. and Planet. Change, 1, 175-194.

- 1992: Continental cloudiness changes this century. Geo Journal, 27.3, 255-262.

Intergovernmental Panel on Climate Change (IPCC), 1990: Scientific Assessment of Climate Change: World Meteorological Organization/United Nations Environmental Programme, Geneva, Switzerland, Cambridge University Press, 366 pp. incl. appendixes.

, 1992: Climate Change 1992: The supplementary Report to the IPCC Scientific Assessment. World Meteorological Organization/United Nations Environmental Programme, Geneva, Switzerland, Cambridge University Press, 200 pp. including appendixes.

Jones, P. A., and A. Henderson-Sellers, 1992: Historical records of cloudiness and sunshine in Australia. J. Climate, 5, 260-267.

Jones, P.D., 1988: Hemispheric surface air temperature variations: Recent trends and an update to 1987. J. Climate, 1, 654-660.

- 1992: Maximum and minimum temperature trends over Sudan. International Temperature Workshop, D. E. Parker, Ed. Hadley Research Centre.

, S. C. B. Raper, R. S. Bradley, H. F. Diaz, P. M. Kelly, and T. M. L. Wigley, 1986a: Northern Hemisphere surface air temperature variations, 1851-1984. J. Climate Appl. Meteor., 25, 161179.

$-,-1,-,-$, and,$- 1986 \mathrm{~b}$ : Southern Hemisphere surface air temperature variations, 1851-1984. J. Climate Appl. Meteor., 25, 1213-1230.

- P. Ya. Groisman, M. Coughlan, N. Plummer, W.-C. Wang, and T. R. Karl, 1990: Assessment of urbanization effects in time series of surface air temperature over land. Nature, 347, 169172.

Karl, T. R., G. Kukla, and J. Gavin, 1984: Decreasing diumal temperature range in the United States and Canada from 19411980. J. Climate Appi. Meteor., 23, 1489-1504.

$\longrightarrow, \ldots$, and $-1986 \mathrm{a}$ : Relationship between temperature range and precipitation trends in the United States and Canada 194 †-80. J. Climate Appl. Meteor., 26, 1878-1886.

_. C. N. Williams, Jr., and P. J. Young, 1986b: A model to estimate the time of observation bias associated with mean monthly maximum, minimum and mean temperatures for the United States. J. Climate Appl. Meteor., 25, 145-160.

_- H. F. Diaz, and G. Kukla, 1988: Urbanization: Its detection and effect in the United States climate record. J. Climate, 1, 1099 1123.

, C. N. Williams, F. T. Quinlan, and T. A. Boden, 1990: United States Historical Climatology Network (HCN) Serial Temperature and Precipitation Data. U.S. Dept. of Energy, ORNLCDIAC30 NDP-019/RI 83 pp. plus appendixes.

- G. Kukla, V. N. Razuvayev, M. J. Changery, R. G. Quayle, R. R. Heim, Jr., D. R. Easterling, and C. B. Fu, 1991: Global 
warming: Evidence for asymmetric diurnal temperature change. Geophvs. Res. Lett., 18, 2253-2256.

Kruss, P. O., K. A. Y. Khan, F. M. Q. Malik, M. Muslehuddin, and A Majid, 1992: Cooling over monsoonal Pakistan. Fitth International Meeting on Statistical Climatology, Environment Canada $27 \mathrm{pp}$.

Landsberg, H. E., 1981: The Urban Climate. Academic Press, 285 pp. Milly, P. C. D., 1992: Potential evaporation and soil moisture in general circulation models. J. Climate, 5, 209-226.

Penner. J. E., R. E. Dickinson, and C. A. O'Neill, 1992: Effects of aerosol from biomass burning on the global radiation budget. Science, 256, 1432-1433.

Plantico, M. S., T. R. Karl, G. Kukla, and J. Gavin, 1990: Is recent climate change across the United States related to rising levels of anthropogenic greenhouse gases? J. Geophys. Res., 95, 16 617-16 637.

Quayle, R. G., D. R. Easterling, T. R. Karl, and P. M. Hughes, 1991: Effects of recent thermometer changes in the cooperative station network. Bull. Amer. Meteor. Soc., 72, 1718-1723.

Rind, D., R. Goldberg, and R. Ruedy, 1989: Change in climate variability in the 21 st century. Climate Change, 14, 5-37.
Schlesinger, M. E., and J. F. B. Mitchell, 1985: Model projection of the equilibrium climatic response to increased carbon dioxide. Projecting the Effects of Increasing Carbon Dioxide. M. C. MacCrochen and F. M. Luther, Eds. Department of Energy, DOE/ER-0237 57-80.

Shea, D., R. Jenne, and C. Ropelewski, 1992: NCAR data sets with daily maximum and minimum temperatures. International Temperature Workshop. D. E. Parker, Ed., Hadley Research Centre, $5 \mathrm{pp}$.

Solow, A. R., 1987: Testing for climate change: An application of the two-phase regression made. J. Climate Appl. Meteor., 26, 14011405.

U.S. Department of Commerce, 1950: Census of Agriculture, Vol. III. Irrigation of Agricultural Lands. (Available through the US Govt. Printing Office.)

- 1988: Farm and Ranch Irrigation Survey, Vol 3, Part 1. (Available through the US Govt. Printing Office.)

Wang, W.-C., Z.Zeng, T. R. Karl, 1990: Urban heat islands in China. Geophys. Res. Lett., 17, 2377-2389. 


\section{INTERNAL DISTRIBUTION}

1. D. Alvic, UT/EERC

2. J. Barkenbus, UT/EERC

3. L. D. Bates, K-1201, MS-7256

4. T. W. Beaty, 1000 , MS-6335

5. B. A. Bervin, 4500 S, MS-6124

6. T. A. Boden, 1000 , MS-6335

7. M. D. Burtis, 1000 , MS-6335

8. J. B. Cannon, $4500 \mathrm{~N}, \mathrm{MS}-6189$

9. R. B. Cook, 1505, MS-6038

10. J. H. Cushman, 1503, MS-6352

11. R. M. Cushman, 1000, MS-6335

12. V. H. Dale, 1505 , MS-6035

13. R. C. Daniels, 1000 , MS-6335

14. M. P. Farrell, 4500 N, MS- 6250

15. D. E. Fowler, 1505, MS-6035

16. S. G. Hildebrand, 1505, MS-6037

17. S. B. Jones, 1000 , MS-6335

18. D. P. Kaiser, 1000, MS-6335

19. P. Kanciruk, 1507, MS-6407

20. A. Kozyr, 1000, MS-6335

21. S. E. Lindberg, 1505, MS-6038

22. J. M. Loar, 1504, MS-6351

23. D. L. Lue, 1000 , MS-6335

24. G. Marland, 1000 , MS-6335
25. L. J. Morris, 1000 , MS-6335

26. T. R. Nelson, 1000 , MS-6335

27. D. E. Reichle, $4500 \mathrm{~N}$, MS-6253

28. F. E. Sharples, 1505, MS-6036

29. D. E. Shepherd, 1000, MS-6335

30. D. S. Shriner, 1505, MS-6036

31. J. W. Simmons, 2506, MS-6039

32. T. Stamm, UT/EERC

33. F. W. Stoss, 1000 , MS -6335

34. S. H. Stow, 1505, MS-6038

35. P. L. Sullenberger, 1000, MS-6335

36-235. CDIAC

236. Central Library, 4500N, MS-6291

237-251. ESD Library, 1505, MS-6035

252-253. Laboratory Records Dept., 4500N, MS-6285

254. Laboratory Records Dept., - RC

255. ORNL Patent Section, 4500N, MS-6258

256. ORNL Public Relations, 4500N, MS-6213

257. ORNL Y-12 Tech. Library, 9711-1, MS-8104

\section{EXTERNAL DISTRIBUTION}

258. S. Alexander, Geosciences Department, Pennsylvania State University, University Park, PA 16802

259. V. Alexander, School of Fisheries and Ocean Sciences, University of Alaska, Fairbanks, AK 99775

260. J. H. Allen, National Oceanic and Atmospheric Administration, National Geophysical Data Center, Code E/GC2, 325 Broadway, Boulder, CO 80303

261. A. Andersen, U.S. Department of Energy, Code EI-62, 1000 Independence Ave. SW, Washington, D.C. 20585

262. P. Andre, U.S. Department of Agriculture, National Agricultural Library, 10301 Baltimore Blvd., Beltsville, MD 20705

263. J. K. Angell, NOAA-Air Resources Laboratory (R/E/AR), SSMC3, Station 3361, 1315 East West Highway, Silver Spring, Maryland 20910

264. E. B. Apasova, Research Institute of Hydrometeorological Information-World Data Center, 6 Korolyov Street, Obninsk, Russia

265. D. C. Bader, Battelle Pacific Northwest Laboratory, 901 D Street SW, Suite 900 , Washington, D.C. 20024-2115

266. R. H. Ball, U.S. Department of Energy, Code EH-3, 1000 Independence Ave. SW, Washington, D.C. 20585 
267. R. C. Barry, University of Colorado, World Data Center A, Glaciology, CIRES, Campus Box 449, Boulder, CO 80309-0449

268. D. Barth, Director, Harry Reid Center for Environmental Studies, 4505 South Maryland Parkway, University of Nevada, Las Vegas, NV 89154

269. G. S. Barton, GCRIO, 1747 Pennsylvania Ave. NW, Suite 200, Washington, D.C. 20006

270. M. Baumgardner, Department of Agronomy, Purdue University, 1220 Potter Drive, West Lafayette, IN 47907

271. T. A. Belokrylova, Research Institute of Hydrometeorological Information-World Data Center, 6 Korolyov Street, Obninsk, Russia

272. D. Bergamaschi, OES-OA/MST, Room 5081, Department of State, Washington, D.C. 20520

273. B. Bernstein, EcoAnalysis, Inc., Arcade Plaza, Suite A, 221 East Matilija, Ojai, CA 93023-0279

274. G. Brasseur, National Center for Atmospheric Research, P.O. Box 3000, Boulder, CO 80307-3000

275. F. Bretherton, Chair, Space Science and Engineering Center, University of Wisconsin, 1225 West Dayton Street, Madison, WI 53706

276. K. R. Briffa, Climatic Research Unit, School of Environmental Sciences, University of East Anglia, Norwich NR47TJ, United Kingdom

277. M. Broido, Environmental Sciences Division, ER-74, U.S. Department of Energy, Washington, D.C. 20585

278. D. A. Bruns, Chair, Department of Earth and Environmental Sciences, Wilkes University, Wilkes-Barre, PA 18766

279. D. Butler, NASA Headquarters, Mail Code SED, Washington, DC 20546

280. R. Calender, Oceanographer of the Navy, U.S. Naval Observatory, 34th St. and Massachusetts Ave. NW, Washington, D.C. 20392-5101

281. M. S. Carter, WDC-A for Rotation of the Earth, Time Service Department, U.S. Naval Observatory, Washington, DC 20392-5100

282. D. Changnon, Department of Geography, Northem Illinois University, DeKalb, Illinois 60115-2854

283. M. A. Chinnery, National Oceanic and Atmospheric Administration, National Geophysical Data Center, Code E/GC2, 325 Broadway, Boulder, CO 80303

284. C. Christensen, Department of Interior, Office of Information Resources Management, 1849 C St. NW, MS-5321, Washington, D.C. 20240

285. E. Christian, U.S. Geological Survey, Information Systems Division, Reston, VA 22092

286. J. R. Christy, The University of Alabama in Huntsville, Atmospheric Science Program, Huntsville, Alabama 35899

287. D. Collins, Jet Propulsion Laboratory, 4800 Oak Grove Drive, Pasadena, CA 91109

288. P. Comillon, Graduate School of Oceanography, Narragansett Bay Campus, University of Rhode Island, Narragansett, RI 02882

289. P. A. Crowley, Environmental Sciences Division, Office of Health and Environmental Research, ER-74, U.S. Department of Energy, Washington, D.C. 20585

290. H. Croze, Global Environment Monitoring Systems, UNEP, P. O. Box 30552, Nairobi, Kenya

291. R. C. Dahlman, Environmental Sciences Division, Office of Health and Environmental Research, ER-74, U.S. Department of Energy, Washington, D.C. 20585

292. K. Davidson, Deputy Director, National Climatic Data Center, Federal Building, Asheville, NC 28801 
293. L. DeMouy, U.S. Department of Energy, Code EI-623, 1000 Independence Ave. SW, Washington, D.C. 20585

294. S. Digby, Jet Propulsion Laboratory, 4800 Oak Grove Drive, Pasadena, CA 91109

295. B. C. Douglas, National Oceanographic Data Center, NOAA, Room 406, Universal Building South, 1825 Connecticut Ave. NW, Washington, DC 20235

296. W. Draeger, EROS Data Center, U.S. Geological Survey, Sioux Falls, SD 57198

297. D. R. Easterling, NOAA National Climatic Data Center, Federal Building, Asheville, NC 28801

298. J. J. Easton, Jr., Assistant Secretary for International Affairs and Energy Emergencies, (IE-1), Department of Energy, Washington, D.C. 20585

299. J. W. Elwood, Environmental Sciences Division, Office of Health and Environmental Research, ER-74, U.S. Department of Energy, Washington, D.C. 20585

300. Energy Library (HR-832.1/GTN), U.S. Department of Energy, Office of Administration and Management, G-034 Germantown, Washington, D.C. 20585

301. Energy Library (HR-832.2/WAS), U.S. Department of Energy, Office of Administration and Management, GA-138 Forrestal Building, Washington, D.C. 20585

302. L. Enomoto, NOAA/NESDIS, FB-4, Room 0110, Washington, D.C. 20233

303. G. Evans, U.S. Department of Agriculture, Global Change Program Office, 1621 N. Kent Street, Room 60LL, Arlington, VA 22209

304. R. N. Farvolden, Professor, Department of Earth Sciences, University of Waterloo, Waterloo, Ontario N2L 3G1 Canada

305. J. Fein, National Science Foundation, Atmospheric Science Division, $1800 \mathrm{G}$ St. NW, Washington, D.C. 20550

306. W. Ferrell, U.S. Department of Energy, 1000 Independence Ave. SW, Washington, D.C. 20585

307. J. Filson, National Earthquake Information Center, U.S. Geological Survey, Denver Federal Center, P.O. Box 20546, Denver, CO 80225

308. B. F. Findlay, Environment Canada, Atmospheric Environment Service, Climate Research Branch, Downsview, Ontario, Canada M3H5T4

309. J. F. Franklin, Bloedel Professor of Ecosystem Analysis, College of Forest Resources, University of Washington, Anderson Hall (AR-10), Seattle, WA 98195

310. D. W. Freckman, Director, College of Natural Resources, 101 Natural Resources Building, Colorado State University, Fort Collins, CO 80523

311. P. Frich, Danish Meteorological Institute, Lyngbyvej 100, DK-2100, Copenhagen, Denmark

312. A. Ghovanlou, Technical Director, Space Systems Division, Mitre Corporation, 7525 Colshire Drive, MS Z650, McLean, VA 22102

313. S. N. Goldstein, National Science Foundation, 1800 G St. NW, Room 416, Washington, D.C. 20550

314. S. Graves, NASA, Code SED, 600 Independence Ave. SW, Washington, D.C. 20546

315. J. L. Green, National Space Science Data Center, NASA Goddard Space Flight Center, Code 630.2, Greenbelt, MD 20771

316. J. M. Gregory, Climatic Research Unit, School of Environmental Sciences, University of East Anglia, Norwich NR47TJ, United Kingdom

317. P. Ya. Groisman, Dept. of Geology and Geography, Morrill Science Center, University of Massachusetts, Amherst, MA 01003

318. D. W. Gullett, Environment Canada, Atmospheric Environment Service, Climate Research Branch, Downsview, Ontario, Canada M3H5T4

319. K. Hadeen, NOAA National Climatic Data Center, Federal Building, Asheville, NC 28801 
320. M. Halpert, Climate Prediction Center, NOAA/NWS, 5200 Auth Road, Camp Springs, MD 20746

321. J. Hansen, NASA Goddard Space Flight Center, Institute for Space Studies, 2880 Broadway, New York, New York 10025

322. R. Hayes, Oceanographer of the Navy, U.S. Naval Observatory, 34th St. and Massachusetts Ave. NW, Washington, D.C. 20392-5101

323. G. M. Homberger, Professor, Department of Environmental Sciences, University of Virginia, Charlottesville, VA 22903

324. J. C. Houghton, Environmental Sciences Division, Office of Health and Environmental Research, ER-74, U.S. Department of Energy, Washington, D.C. 20585

325. P. Y. Hughes, NOAA National Climatic Data Center, Federal Building, Asheville, NC 28801

326. M. K. Hughes, Laboratory Tree-Ring Research, University of Arizona, 1105 W. Stadium, Tucson, AZ 85721

327. W. J. Hughes, Center for Space Physics, Boston University, 725 Commonwealth Avenue, Boston, MA 02215

328. M. Hulme, Climatic Research Unit, School of Environmental Sciences, University of East Anglia, Norwich NR47TJ, United Kingdom

329. G. Hunolt, NASA, Code SED, 600 Independence Ave. SW, Washington, D.C. 20546

330. R. Jenne, National Center for Atmospheric Research, P.O. Box 3000, 1850 Table Mesa Drive, Boulder, CO 80307-3000

331. K. C. Jezek, Byrd Polar Research Center, The Ohio State University, 108 Scott Hall, 1090 Carmack Road, Columbus, OH 43210-1002

332. P. D. Jones, Climatic Research Unit, School of Environmental Sciences, University of East Anglia, Norwich NR47TJ, United Kingdom

333. G. Y. Jordy, Director, Office of Program Analysis, Office of Energy Research, ER-30, G-226, U.S. Department of Energy, Washington, D.C. 20545.

334. T. R. Karl, National Climatic Data Center, Federal Building, Asheville, NC 28801

335. V. V. Koknaeva, State Hydrological Institute, 23, Second Line, St. Petersburg, 199053, Russia

336. J. H. King, WDC-A for Rockets and Satellites, National Space Science Data Center, Code 930.2, NASA Goddard Space Flight Center, Greenbelt, MD 20771

337. R. W. Knight, NOAA National Climatic Data Center, Federal Building, Asheville, NC 28801

338. D. T. Lauer, EROS Data Center, U.S. Geological Survey, Sioux Falls, SD 57198

339. J. D. Laver, Climate Prediction Center, NOAA/NWS, 5200 Auth Road, Room 800, Camp Springs, MD 20746

340. B. Lavery, Bureau of Meteorology Research Centre, P.O. Box 1289K, Melboume 3001, Australia

341. S. Levitus, WDC-A for Oceanography, NOAA/NESDIS, E/OC23, Universal Building, Room 409, 1825 Connecticut Ave. NW, Washington, DC 20235

342. A. M. Linn, Program Officer, BESR, National Academy of Sciences, Harris Building 372, 2001 Wisconsin Ave. NW, Washington, DC 20007

343. M. S. Loughridge, National Oceanic and Atmospheric Administration, National Geophysical Data Center, Code E/GC3, 325 Broadway, Boulder, CO 80303

344. G. H. Ludwig, HC 33, Box 641, Winchester, VA 22601 
345. K. M. Lugina, State Hydrological Institute, 23, Second Line, St. Petersburg, 199053, Russia

346. P. Lunn, Environmental Sciences Division, Office of Health and Environmental Research, ER-74, U.S. Department of Energy, Washington, D.C. 20585

347. T. H. Mace, U.S. Environmental Protection Agency, Room 1123 West Tower, $401 \mathrm{M}$ St. SW, Washington, D.C. 20460

348. L. Malone, Environment Canada, Atmospheric Environment Service, Climate Research Branch, Downsview, Ontario, Canada M3H5T4

349. R. A. Martuganov, Research Institute of Hydrometeorological Information-World Data Center, 6 Korolyov Street, Obninsk, Russia

350. L. McGoldrick, SM Systems and Research Corp., 300 D St. SW, Suite 840, Washington, D.C. 20024

351. M. K. McNutt, Department of Earth, Atmosphere, and Planetary Sciences, Building 54, Room 82226, Massachusetts Institute of Technology, 54 Ames Street, Cambridge, MA 021339

352. L. Mearns, National Center for Atmospheric Research, P.O. Box 3000, 1850 Table Mesa Drive, Boulder, CO 80307-3000

353. L. Meredith, USRA, 300 D St. SW, Suite 801, Washington, D.C. 20024

354. H. Meyers, WDC-A for Solid Earth Geophysics, National Geophysical Data Center, NOAA, E/GC1, 325 Broadway, Boulder, CO 80303

355. C. Miller, NOAA/NESDIS, 1825 Connecticut Ave. NW, Suite 506, Washington, DC 20235

356. D. Miskus, Climate Prediction Center, NOAA/NWS, 5200 Auth Road, Room 800, Camp Springs, MD 20746

357. R. E. Munn, University of Toronto, Institute for Environmental Studies, Toronto, Ontario M5S 184, Canada

358. B. Niemann, U.S. Environmental Protection Agency, PM-223X, 401 M St. SW, Washington, D.C. 20460

359. N. Nicholls, Bureau of Meteorology Research Centre, P.O. Box 1289K, Melboume 3001, Australia

360. S. E. Nicholson, Department of Meteorology, The Florida State University, Tallahassee, Florida 32306-3034

361. S. Nishioka, Director, Center for Global Environmental Research, National Institute for Environmental Studies, 16-2 Onogawa, Tsukuba, Ibaraki 305, Japan

362. S. Okimasa, Head, WMO World Data Center for Greenhouse Gases, 1-3-4 Otemachi, Chiyoda-ku, Tokyo 100, Japan

363. C. Olsen, Environmental Sciences Division, Office of Energy Research, ER-74, U.S. Department of Energy, Washington, D.C. 20585

364. R. H. Olsen, Vice President for Research, University of Michigan, Medical Science Building II, \#5605, 1301 East Catherine Street, Ann Arbor, MI 48109-0610

365. J. T. Overpeck, National Oceanic and Atmospheric Administration, National Geophysical Data Center, 325 Broadway E/GC, Boulder, CO 80303

366. B. Parra, Environmental Sciences Division, Office of Health and Environmental Research, ER-74, U.S. Department of Energy, Washington, D.C. 20585

367. W. Parton, Natural Resource Ecology Laboratory, Colorado State University, Fort Collins, CO 80523

368. A. Patrinos, Associate Director, Office of Health and Environmental Research, ER-74, U.S. Department of Energy, Washington, D.C. 20585 
369. W. Person, National Earthquake Information Center, U.S. Geological Survey, Box 25046, Mail Stop 967, Denver Federal Center, Denver, CO 80225-0046

370. L. Pettinger, National Mapping Division, USGS/DOI, 590 National Center, Reston, VA 22092

371. T. A. Potemra, Applied Physics Laboratory, The Johns Hopkins University, Johns Hopkins Road, Laurel, MD 20723-6099

372. N. Plummer, National Climate Center, Bureau of Meteorology, GPO Box 1289K, Melbourne, Victoria 3001 Australia

373. R. Rand, USDA/NAL/ISD/DAB, 10301 Baltimore Blvd., Beltsville, MD 20705-2351

374. I. Rasool, Lab de Meteorologie, Dynamique, Du C.N.R.S., Ecole Normale Superieure, 24 Rue Lhomond, 75231 Paris, Cedex 05 France

375. V. N. Razuvaev, Research Institute of Hydrometeorological Information-World Data Center, 6 Korolyov Street, Obninsk, Russia

376. J. Reycraft, Environment Canada, Atmospheric Environment Service, Climate Research Branch, Downsview, Ontario, Canada M3H5T4

377. M. R. Riches, Office of Health and Environmental Research, ER-74, U.S. Department of Energy, Washington, D.C. 20585

378. A. Robock, NOAA/GFDL, Princeton University, P.O. Box 308, Princeton, NJ 08542

379. M. Rodon-Naveira, EPA/ORD, 401 M Street SW, Washington, D.C. 20460

380. C. Ropelewski, Climate Prediction Center, NOAA/NWS, 5200 Auth Road, Camp Springs, MD 20746

381. E. Russek-Cohen, Department of Animal Sciences, University of Maryland, College Park, MD 20742

382. S. Ruttenberg, University Corporation for Atmospheric Research, CSNET, 3300 Mitchell Lane, Suite 120, Boulder, CO 80301

383. G. S. Sayler, Professor, 10515 Research Drive, Suite 100, The University of Tennessee, Knoxville, TN 37932-2567

384. U. Schneider, Global Precipitation Climatology Centre, Deutscher Wetterdienst, Frankfurter Str. 135, D-W6050 Offenbach a.M., Germany

385. J. Scialdone, Hughes STX, 7701 Greenbelt Road, Suite 400, Greenbelt, MD 20770

386. M. Z. Shaymardanov, Research Institute of Hydrometeorological Information-World Data Center, 6, Korolyov Str., Obninsk, Russia

387. H. H. Shugart, Department of Environmental Sciences, Clark Hall, University of Virginia, Charlottesville, VA 22903

388. A. L. Shumbera, National Oceanic and Atmospheric Administration, WDC-A for Meteorology, National Climatic Data Center, Federal Building, MC E/CC, Asheville, NC 28801

389. J. Simpson, Earth Sciences Director, Severe Storms, Code 912, Building 22, Room 330, NASA/Goddard Space Flight Center, Greenbelt, MD 20771

390. W. R. Skinner, Environment Canada, Atmospheric Environment Service, Climate Research Branch, Downsview, Ontario, Canada M3H5T4

391. S. Sorooshian, Department of Hydrology and Water Resources, University of Arizona, Tucson, AZ 85721

392. A. M. Sterin, Research Institute of Hydrometeorological Information-World Data Center, 6, Korolyov Str., Obninsk, Russia

393. P. M. Steurer, National Climatic Data Center, Database Management Branch, Federal Building, Asheville, NC 28801

394. J. Thieman, NASA/GSFC, Building 26, Room 138, Code 933, Greenbelt, MD 20771 
395. R. E. Thompson, Department of Agriculture, National Agricultural Library, 10301 Baltimore Blvd./5th Floor, Beltsville, MD 20705

396. J. R. G. Townshend, Department of Geography, 1113 Lefrak Hall, University of Maryland, College Park, MD 20742

397. P. F. Uhlir, Assistant Executive Director, Commission on Physical Sciences, Mathematics, and Applications, National Research Council, 2101 Constitution Avenue NW, Washington, D.C. 20418

398. L. Vincent, Environment Canada, Atmospheric Environment Service, Climate Research Branch, Downsview, Ontario, Canada M3H5T4

399. K. Vinnikov, University of Maryland, Department of Meteorology, College Park, MD 20742

400. C. Watts, NOAA/Library, 6009 Executive Blvd., Rockville, MD 20852

401. F. Webster, College of Marine Studies, University of Delaware, Lewes, DE 19958

402. R. Whitewood, Environment Canada, Atmospheric Environment Service, Climate Research Branch, Downsview, Ontario, Canada M3H5T4

403. G. B. Wiersma, Dean, College of Forest Resources, Maine Agricultural Experiment Station, 202 Nutting Hall, University of Maine, Orono, ME 04469

404. R. Williams, U.S. Department of Agriculture, OIRM - Room 414-W, Washington, D.C. 20250

405. H. Wilson, Columbia University Center for the Study of Global Habitability, 2880 Broadway, New York, New York 10025

406. G. Withee, NOAA/NODC, Room 506, 1825 Connecticut Ave. NW, Washington, D.C. 20235

407. F. J. Wobber, Environmental Sciences Division, Office of Health and Environmental Research, ER-74, U.S. Department of Energy, Washington, D.C. 20585

408. L. Wolf, National Academy of Sciences, 2001 Wisconsin Ave. NW, Harris Building 372, Washington, D.C. 20007

409. J. Young, Commission on Physical Sciences, Mathematics, and Applications, National Research Council, 2101 Constitution Avenue NW, Washington, D.C. 20418

410. Z. Zhao, Climatic Research Centre, Chinese Academy of Meteorological Sciences, 46 Baishiqiaolu, Beijing, Peoples Republic of China

411. Office of Assistant Manager for Energy Research and Development, U.S. Department of Energy Oak Ridge Operations, P.O. Box 2001, Oak Ridge, TN 37831-8600

412-413. Office of Scientific and Technical Information, P.O. Box 62, Oak Ridge, TN 37831 